
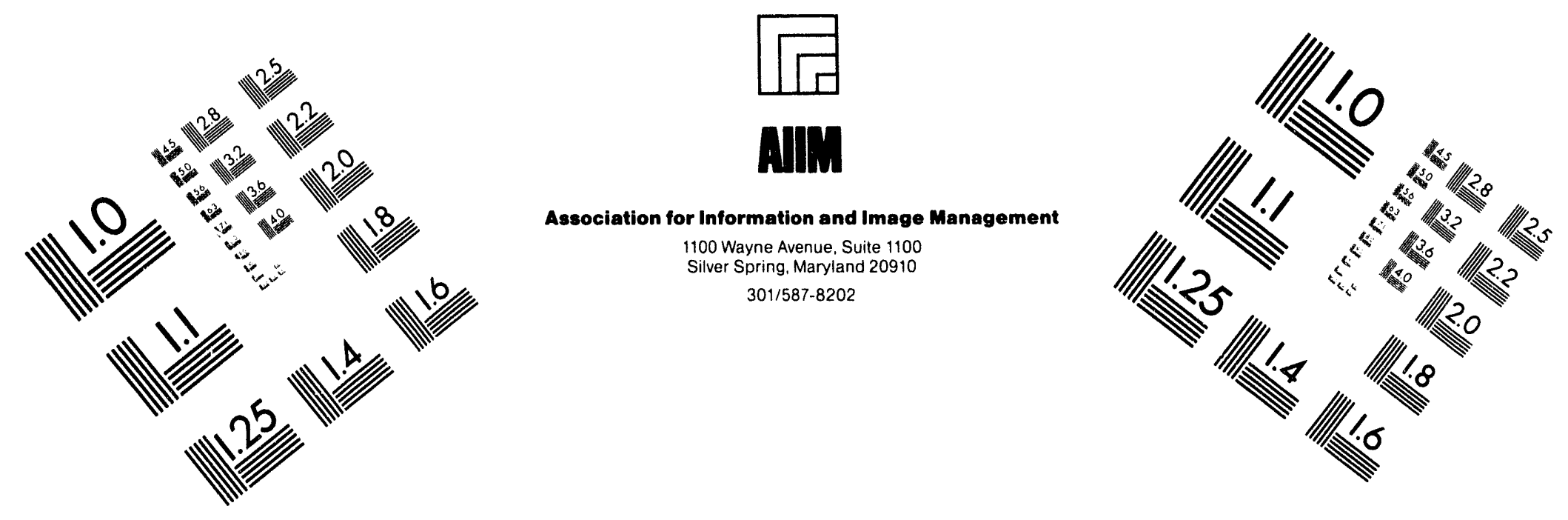

\title{
Centimeter
}

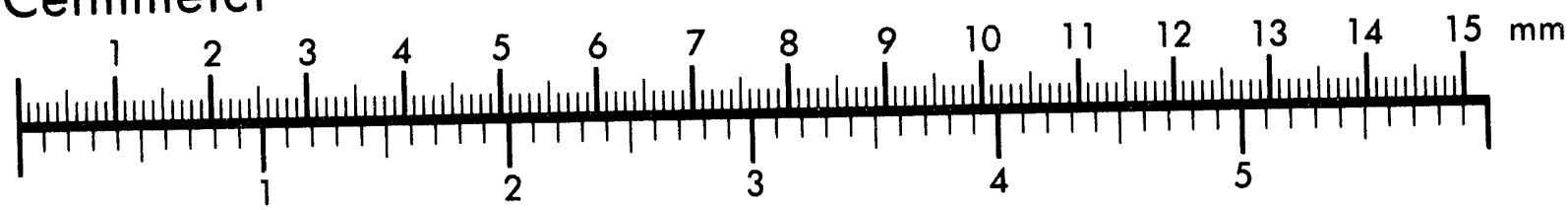

Inches
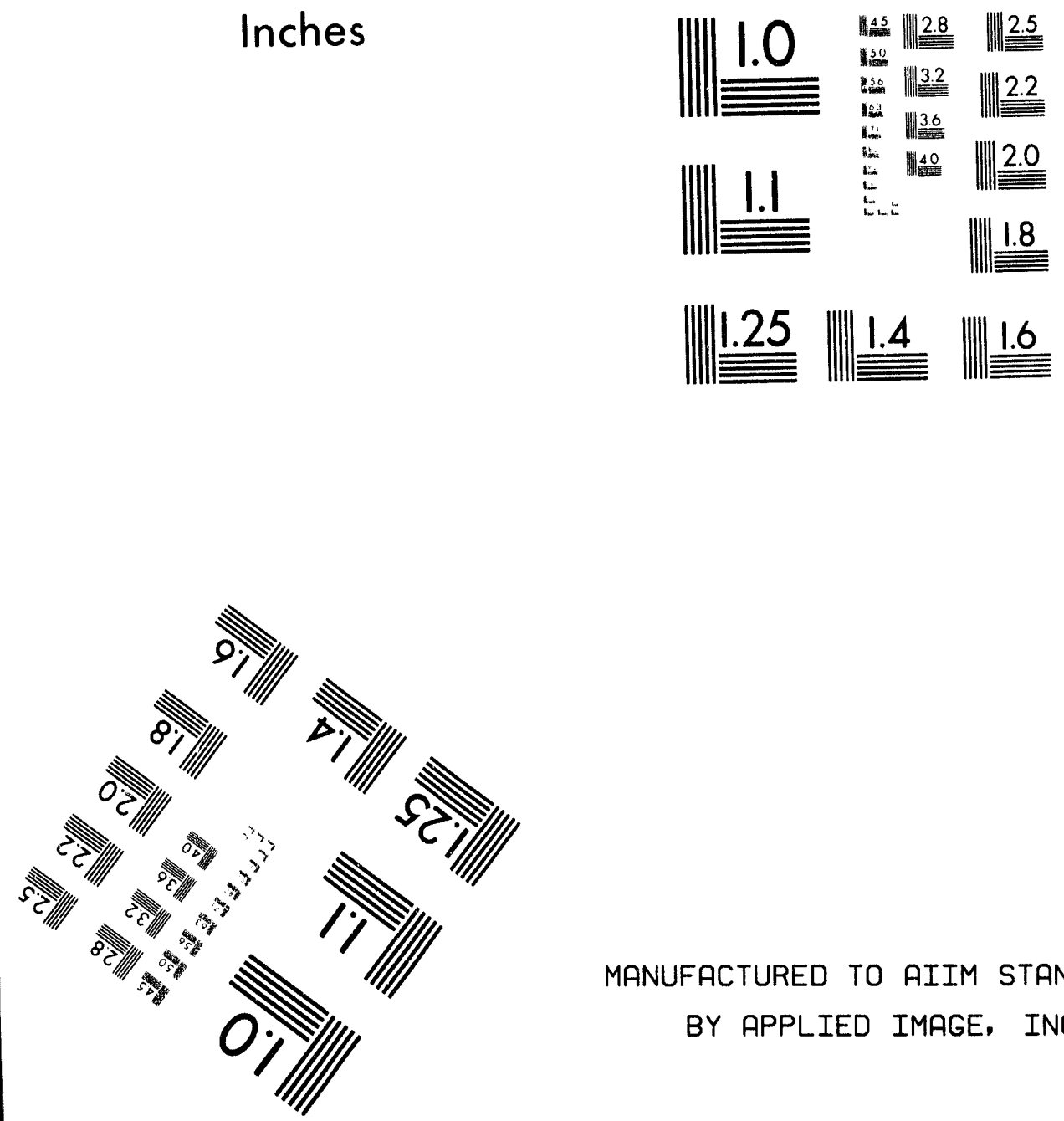

MANUFACTURED TO AIIM STANDARDS

BY APPLIED IMAGE, INC.

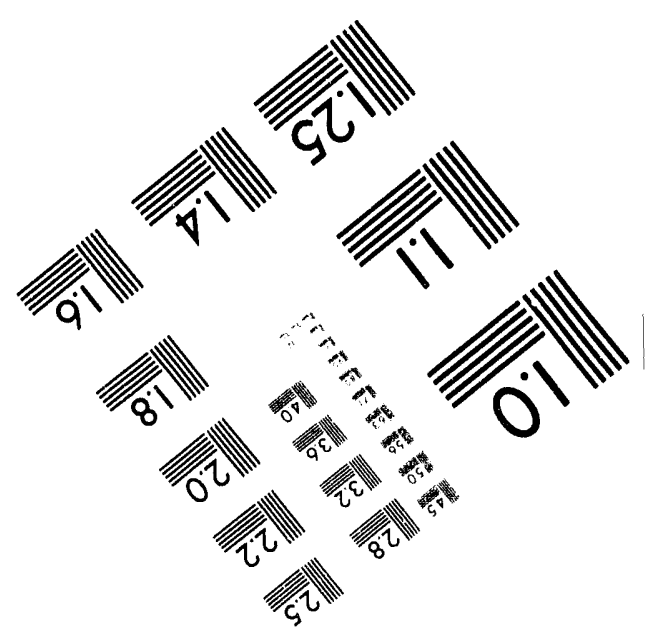



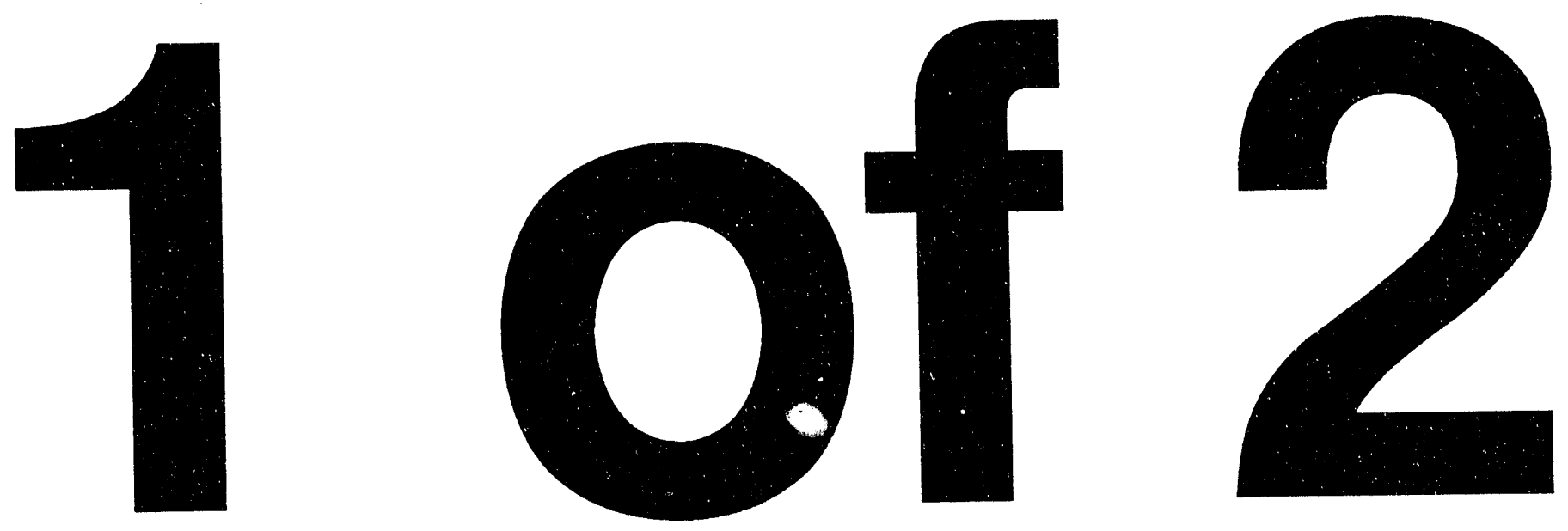
DOE/EIA-M068-C

\section{Model Documentation:}

\section{Electricity Market Module}

\section{Electricity Finance and Pricing Submodule}

\section{March 1994}

Energy Information Administration

Office of Integrated Analysis and Forecasting

Energy Supply and Conversion Division

Nuclear and Electricity Analysis Branch

U.S. Department of Energy

Washington, DC 20585

This report was prepared by the Energy Information Administration, the independent statistical and analytical agency within the Department of Energy. The information comained herein should not be construed as advocating or reflecting any policy position of the Department of Energy or any other organization. 


\section{Table of Contents}

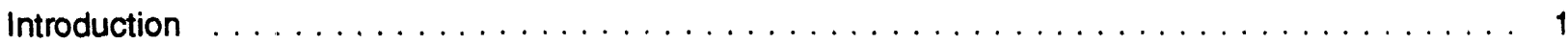

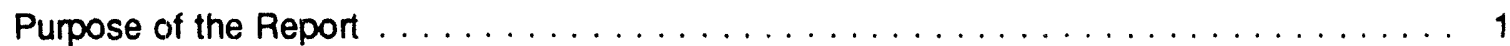

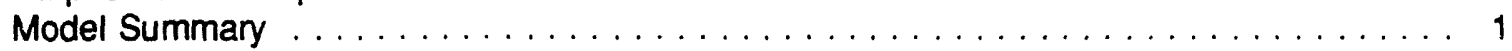

Model Archival Citation and Model Contact $\ldots \ldots \ldots \ldots \ldots \ldots \ldots \ldots \ldots \ldots \ldots$

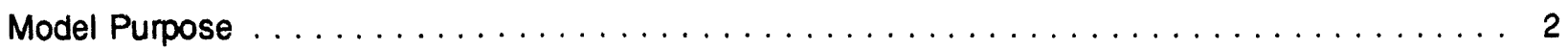

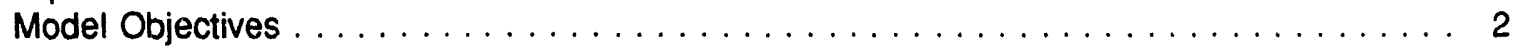

Relationship to Other Models $\ldots \ldots \ldots \ldots \ldots \ldots \ldots \ldots \ldots \ldots \ldots \ldots \ldots$

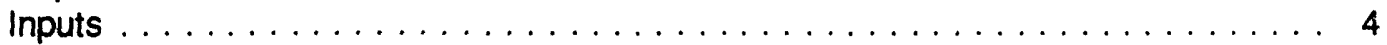

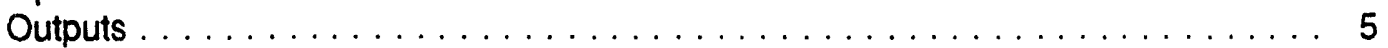

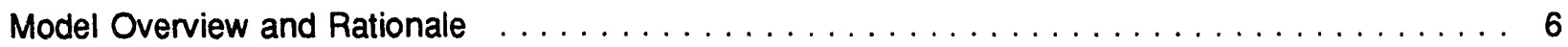

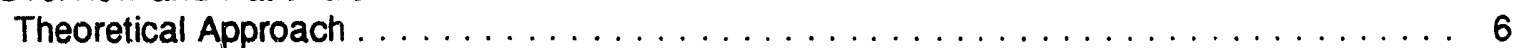

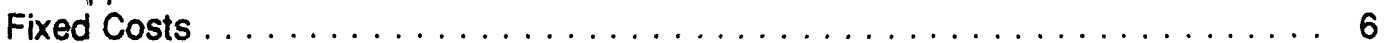

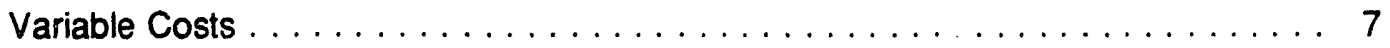

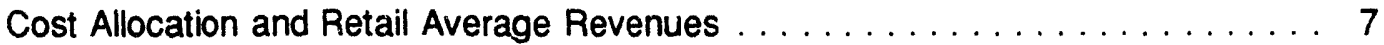

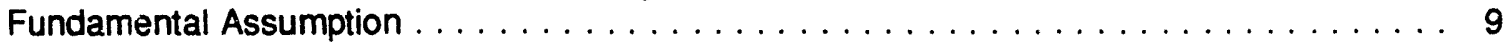

Alternative Approaches and Reasons for Selection $\ldots \ldots \ldots \ldots \ldots \ldots \ldots \ldots \ldots$

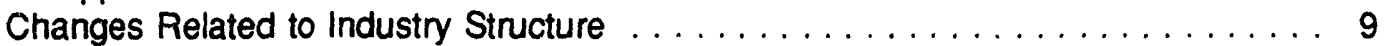

Changes Related to Capital Expenditures . . . . . . . . . . . . . . . . . . . . . 10

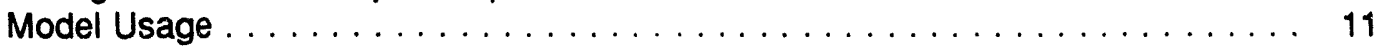

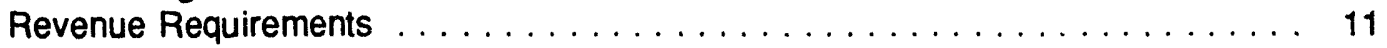

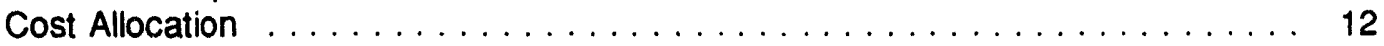

Market Based Rates . . . . . . . . . . . . . . . . . . . . 13

Model Structure:

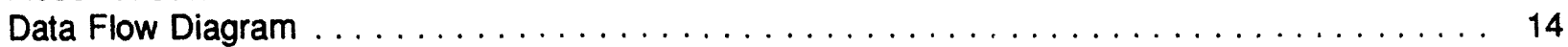

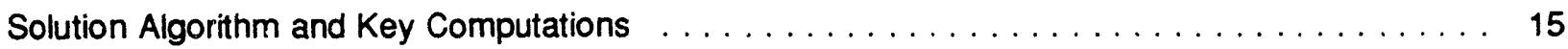

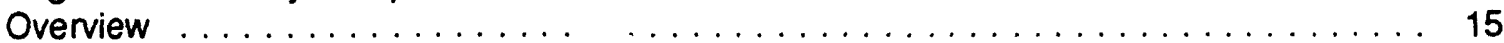

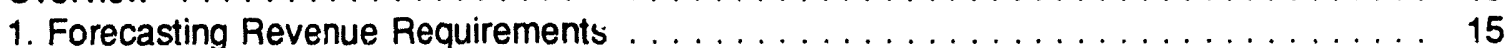

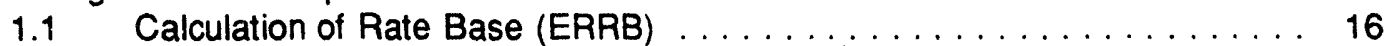

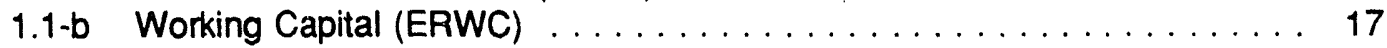

1.1-c Nuclear Fuel Stock (ERNFSN) $\ldots \ldots \ldots \ldots \ldots \ldots \ldots \ldots \ldots$

1.2 Rate of Return (ESRR) $\ldots \ldots \ldots \ldots \ldots \ldots \ldots \ldots \ldots \ldots \ldots \ldots \ldots$

1.2-a Embedded Cost of Long Term Debt (ESEMDT) . . . . . . . . . . 19

1.2-b Embedded Cost of Preferred Stock (ESEMPS) . . . . . . . . . . . . 20

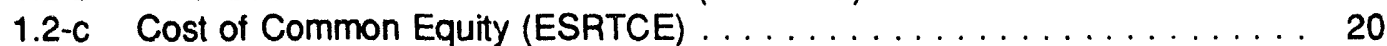

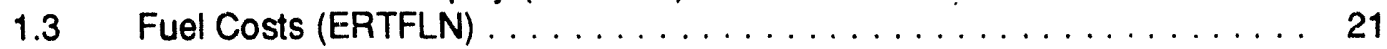

1.4 Operation and Maintenance (O\&M), Excluding Fuel (ERTOMN) . . . . . 21

1.4-a Generation O\&M ............................ 21

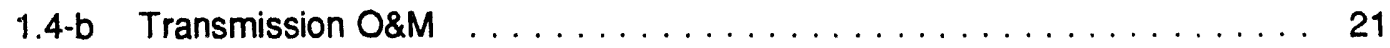

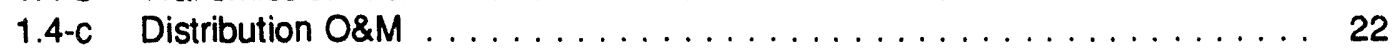

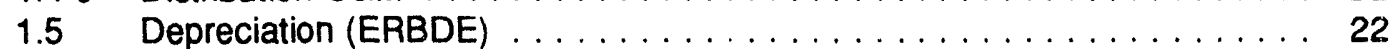

1.6 General Taxes for Regulatory Purposes (GENREG) . . . . . . . . . . . 22

1.7 State Income Taxes for Regulatory Purposes (STAREG) $\ldots \ldots \ldots \ldots .22$

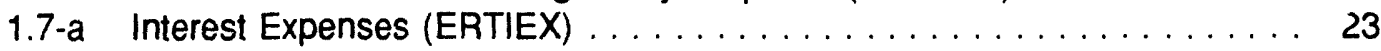

1.7-b Assets Minus Deferrals (ERAMD) $\ldots \ldots \ldots \ldots \ldots \ldots \ldots \ldots \ldots$

Electricity Finance and Pricing Submodule Documentation - April 1994 
$1.8 \quad$ Federal Income Taxes for Regulatory Purposes (FEDREG) . . . . . . . 24

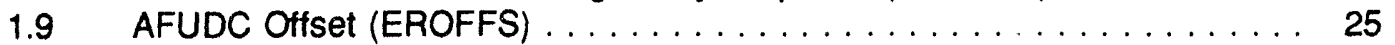

1.10 Net Lease Payments Associated with Sale/Leaseback Transactions

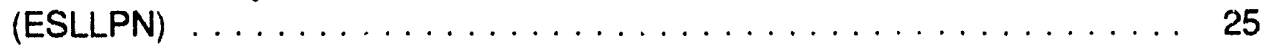

1.11 Net Deferred Phase-in Revenues (EPIND) $\ldots \ldots \ldots \ldots \ldots \ldots \ldots \ldots$

1.12 Resolution of ERRVRQ "Circular" Argument $\ldots \ldots \ldots \ldots \ldots \ldots \ldots$

1.13 Construction Work in Progress (CWIP) $\ldots \ldots \ldots \ldots \ldots \ldots \ldots \ldots$

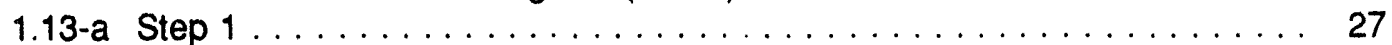

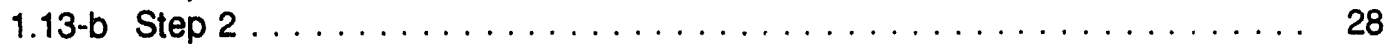

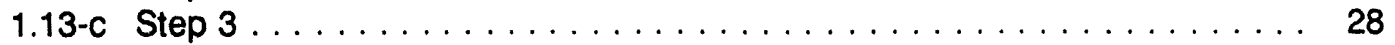

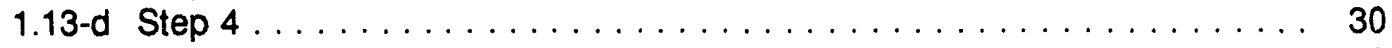

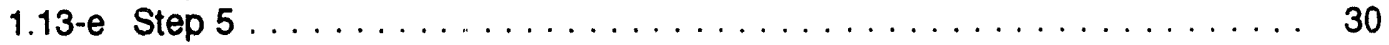

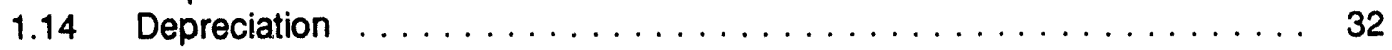

1.14-a Depreciation for Financial Purposes (ERBDE) $\ldots \ldots \ldots \ldots \ldots \ldots \ldots$

1.14-b Depreciation for Tax Purposes ...................... 33

1.14-c Excess Deferred Income Taxes Flowed Back to Ratepayers (EREDTF) . . 35

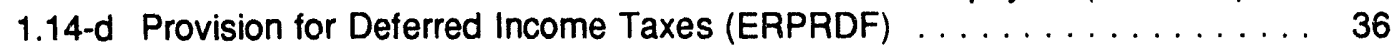

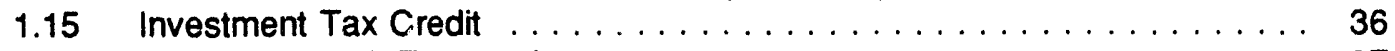

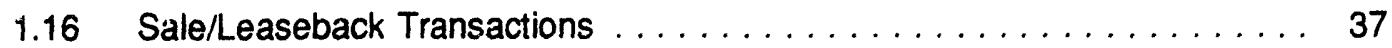

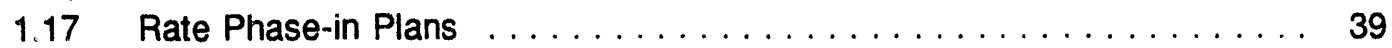

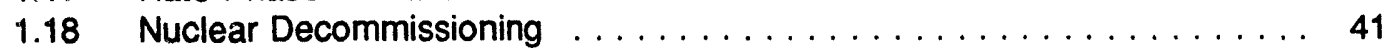

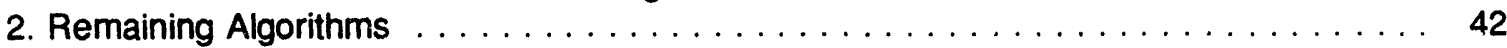

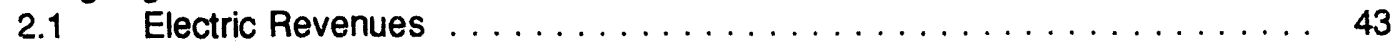

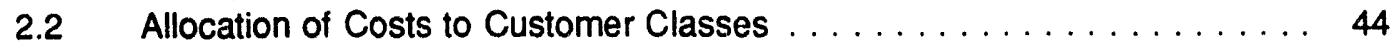

2.2-a Sales Method $\ldots \ldots \ldots \ldots \ldots \ldots \ldots \ldots \ldots \ldots \ldots \ldots \ldots \ldots$

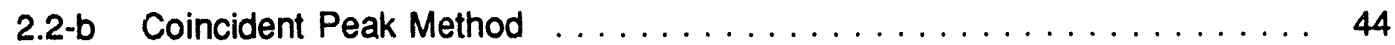

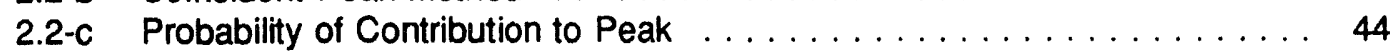

2.2-d Non-Coincident Peak Method ........................ 44

2.2-e Average and Excess Demand Using Coincident Peak . . . . . . . . . . 45

2.2-f Average and Excess Demand Using Probability of Contribution to Peak .. 45

2.2-g Allocation of Costs to Customer Classes . . . . . . . . . . . . . 45

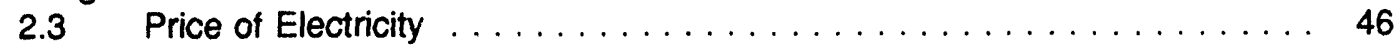

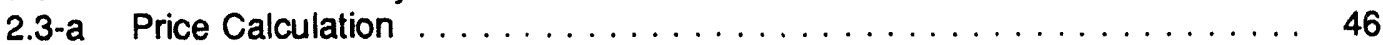

2.3-b Benchmark/Subsidization Calculation ................. 46

2.3-c Calculation of Prices with Benchmarking and Subsidization . . . . . . 47

2.4 Taxes ............................. 48

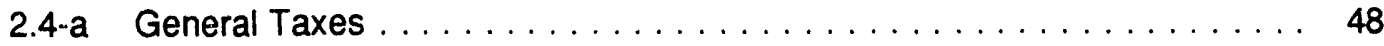

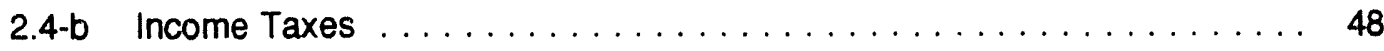

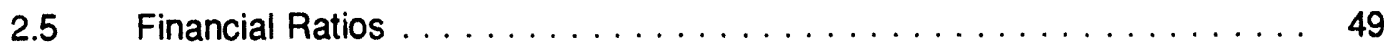

Appendix A

Listing of Subroutines and Subroutine Functions $\ldots \ldots \ldots \ldots \ldots \ldots \ldots \ldots \ldots \ldots \ldots \ldots$

Appendix B

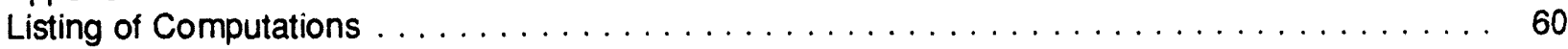

Appendix C

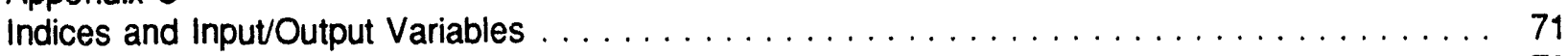

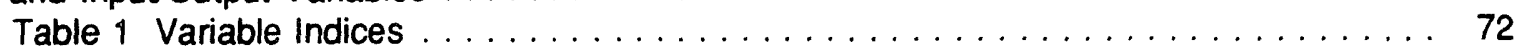

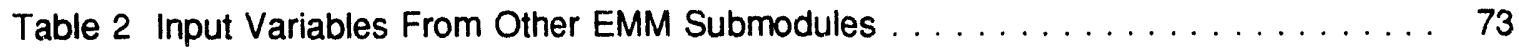

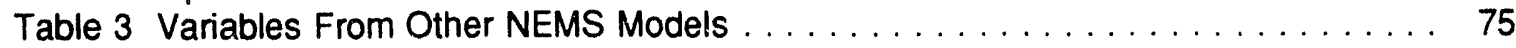

Table 4 Input Variables From External Sources $\ldots \ldots \ldots \ldots \ldots \ldots \ldots \ldots \ldots$ 
Appendix D

Bibliography

Appendix $E$

Model Abstract

Appendix $F$

Data Quality and Estimation

Regulatory Focus, Regulatory Research Associates, Inc. (RRA), Various Issues . . . . . 94

Economic Recovery Act of 1981 (ERTA) and the Tax Reform Act of 1986 (TRA) . . . . . 95

Standard and Poors Industry Surveys (S\&PIS), Utilities-Electric Current Analysis, Standard

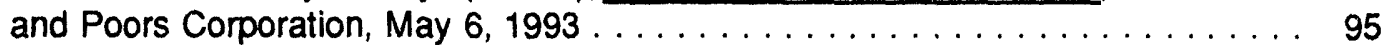

Energy Information Administration Form 412 (ElA412), the Rural Electrification

Administration Form 7 (REA7), and the Federal Energy Regulatory Commission

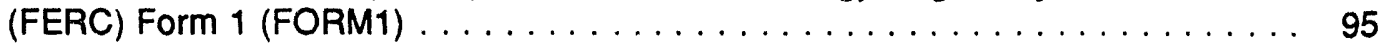

Assumptions made by analysts at the Energy Information Administration (EIA) $\ldots \ldots \ldots$. 97 


\section{Introduction}

\section{Purpose of the Report}

The purpose of this report is to define the objectives of the model, describe its basic approach, and provide detail on how it works. This documentation is intended as a reference document for model analysts, users, and the public. EIA has a legal obligation to provide adequate documentation in support of its models (Public Law 93-275).

\section{Model Summary}

The EFP is a regulatory accounting model that projects electricity prices. The model first solves for revenue requirements ${ }^{1}$ by building up a rate base ${ }^{2}$, calculating a return on rate base, and adding the allowed expenses. Average revenues (prices) are calculated based on assumptions regarding regulatory lag and customer cost allocation methods. The model then solves for the internal cash flow and analyzes the need for external financing to meet necessary capital expenditures. Finally, the EFP builds up the financial statements.

The EFP is used in conjunction with the National Energy Modeling System (NEMS). Inputs to the EFP include the forecast generating capacity expansion plans, operating costs, regulatory environment, and financial data. The outputs include forecasts of income statements, balance sheets, revenue requirements, and electricity prices.

\section{Model Archival Citation and Model Contact}

The EFP will be archived as a part of the National Energy Modeling System. The model contact is Art Holland (202-586-2026).

'Revenue requirements are the costs that a ratemaking authority allows a regulated utility to recover from ratepayers.

${ }^{2} T$ The ratebase is the total value (original cost less accumulated straight line depreciation and excluded tax deferrals) of all capitalized assets on which the regulated utility is allowed by a ratemaking authority to earn a return. 


\section{Model Purpose}

\section{Model Objectives}

The Electricity Finance and Pricing Submodule (EFP) is a component of the Electricity Market Module (EMM), which is part of the National Energy Modeling system. As a component of NEMS, the EFP forecasts financial information for electric utilities on an annual basis given a set of inputs and assumptions concerning forecast capacity expansion plans, operating costs, regulatory environment, and financial data. The outputs of the model include electricity prices by end use sectors for North American Electric Reliability (NERC) and Census regions, financial statements, revenue requirements ${ }^{3}$, and financial ratios for each stage of production (generation, transmission and distribution.)

Electricity prices are determined by allocating projected revenue requirements to each customer class and dividing by the corresponding sales. Because the EFP is an aggregated model, the revenue requirements are allocated according to a representative rate structure for an entire region. The EFP simulates the traditional original-cost or rate-of-return regulatory method where electric utilities have their rates set by local, State, and Federal regulatory commissions. Utilities have rates set so as to allow them to recover their operating costs and earn a rate of retum equal to their cost of capital.

The EFP determines the revenues that the aggregated utility requires in order to operate and earn its allowed profit using an average cost based algorithm. Revenues required for wholesale trades, including generation that is provided by nonutilities ${ }^{4}$, are determined in separate submodules of the Electricity Market Module (EMM) of the National Energy Modeling System (NEMS) and transferred to the EFP as expense items.

There are three exceptions to the use of traditional rate of return regulation for determining revenue requirements in the EFP. These exceptions are sales-leaseback transactions ${ }^{5}$, phase-in plans for new generating units ${ }^{6}$, and disallowances ${ }^{7}$. These exceptions are modeled by exogenously adjusting the

\footnotetext{
${ }^{3}$ Revenue requirements are the costs that a ratemaking authority allows a regulated utility to recover from ratepayers.

${ }^{4}$ Nonutility generators are companies that generate electric power to be sold at wholesale rates to utilities who will in turn sell the power to ultimate consumers. Nonutility generators are nonregulated in that ratemaking commissions generally do not use the exhaustive cost based determination of electricity rates that are used for traditional regulated utilities. Instead, alternate methods for setting their rates have been developed such as a utility avoided cost method for cogenerators, and competitive bidding for independent power producers (IPPs).

${ }^{5} \mathrm{~A}$ sales-leaseback transaction in the electric power industry generally involves the sale by the utility of a newly completed power plant to a group of investors with the understanding that the utility will then operate the plant through a lease arrangement. The advantage to the utility of such an arrangement is that rate shock can be avoided because there is a quick recovery of the costs of building the plant (through the sale proceeds). Payments by the utility for the use of the plant may then be levelized by the lease payments.
}

${ }^{6} A$ phase-in plan also serves to reduce rate shock caused by a new plant entering service. A new plant is introduced into rates in phases to raise rates gradually over time. In many cases, the ratemaking authority will allow the utility to earn a compounded return on the unrecovered portion of the plant, but recovery of these returns is deferred 
forecasted revenue requirements to comply with known information. The revenue that the aggregated utility will actually receive is modeled by adjusting the revenue requirement by a function to simulate regulatory $\mathrm{lag}^{8}$. The model solves for internal cash flow and determines the need for external financing in order to meet capital expenditures.

Revenue requirements are allocated to each of four customer classes: residential, commercial, industrial, and transportation. The allocation process is carried out in three steps. First, all costs are functionalized. That is, they are sorted by stage of production into generation, transmission, and distribution. Second, the functionalized costs are classified according to the service characteristics to which they are related. The four service characteristics are fuel costs, variable operation and maintenance (O\&M) costs, fixed O\&M costs, and capital related costs ${ }^{9}$. Third, these functionalized and classified costs are allocated to the four customer classes and the average revenue for each customer class in each region is determined. In addition to determining customer average revenues on a regional basis, the EFP builds financial statements and ratios using accounting methods that simulate standard industry accounting practice.

Alternative regulatory and financial treatments that can be simulated in the EFP are flow-through versus normalized accounting ${ }^{10}$, construction work in progress (CWIP) versus allowance for funds used during construction (AFUDC) $)^{11}$, alternate levels of allowed rates of return, and varying periods of regulatory lag.

The type of ownership (investor-owned or public) is specified to allow for more precise historic data inputs, varying regulatory, financial, and accounting conditions between ownership types as well as to allow for enhanced analysis flexibilities and capabilities.

The EFP can be used as a quantitative tool to examine a wide variety of policy issues and options. The following are some of the types of studies in which the EFP's predecessor, the National Financial

until a later date as part of the phase-in plan.

\begin{abstract}
${ }^{7} A$ disallowance occurs when a ratemaking authority refuses to allow a utility to recover the costs of building a plant or a portion of a plant through the rates it charges consumers. Grounds for a disallowance could be that the utility has built more generating capacity than it needs, or the ratemaking authority judges that the utility's management was imprudent in some aspect of the manner in which the building project was undertaken.
\end{abstract}

${ }^{8}$ Regulatory lag is the effect that is caused by any time-related deviation in the assumptions that underlie the calculations of electricity prices, such as the differences between forecasted electricity sales and actual sales. The time variable in the EFP controls the period of time that passes before the realization of the change in assumptions.

${ }^{9}$ Capilal related costs include all costs of production other than operation and maintenance (O\&M, including fuel) and all wholesale trade expenses. The return on the ratebase, annual depreciation expenses, and all taxes are three examples of capital related costs.

${ }^{10}$ In flow-through accounting the tax advantages of accelerated depreciation and investment tax credits are passed on directly to ratepayers by way of a reduction in the regulated utility's revenue requirements. In normalized accounting, these tax advantages are amortized over a period of time - usually the useful life of the asset that generated the tax advantage.

${ }^{11}$ In the CWIP scenario, construction costs are added to the ratebase for an inmediate return on investment as they are accrued. In the AFUDC scenario, construction costs are not added to the utility's ratebase until construction is completed and the new asset is operational. Financing costs are accrued in the AFUDC accounts and amortized over the life of the asset.

Electricity Finance and Pricing Submodule Documentation - April 1994 
Statements model (NUFS), has been used in the past to analyze impacts on electricity prices and electric utility financial performance:
- $\quad$ Allowing alternative levels of CWIP in rate base
- Examining the impacts of Federal income tax reform proposals
- Recovering costs associated with canceled nuclear plants
- Analyzing price impacts of proposed acid rain legislation
- Analyzing alternative regulatory or financial environments such as normalization versus flow-through accounting, changes in interest rates or allowed rates of return, and varying regulatory lag
- Analyzing alternative rates of future electricity demand growth
- Examining financial feasibility of least-cost optimal capacity expansion plans
- Implementing alternative capacity expansion plans under different assumptions of cost escalation.

\section{Relationship to Other Models}

\section{Inputs}

The EFP is a submodule of the NEMS. As such, there are several inputs to the EFP which come from other NEMS components ${ }^{12}$. The capacity expansion plan is provided by the Electricity Capacity Planning (ECP) submodule. This includes the year the plant enters service, capacity (megawatts), and cost (dollars per kilowatt). The EFP uses this information to calculate the cost of construction as well as when and how these construction costs are incorporated into electricity rates.

The fuel, and operation and maintenance (O\&M) costs come from the Electricity Fuel Dispatch (EFD) submodule. The EFP uses these data to calculate the revenues that are needed by electric utilities. The revenue requirements are used to calculate electricity prices to be charged to consumers. Each customer class's contribution to peak load comes from the Load and Demand Side Management (LDSM) submodule. The EFP uses these data to allocate costs to customer classes for pricing retail electricity.

Electricity demand comes from the end-use sector demand modules. The EFP uses electricity demand forecasts in its average revenue calculations ${ }^{13}$.

The amount of power purchased from industrial and commercial cogeneration facilities and iefineries (kilowatthours) and the amount paid by utilities is passed from the Electricity Fuel Dispatch (EFD) submodule. The EFP includes this information in its average revenue calculations.

\footnotetext{
${ }^{12}$ Appendix $C$ includes a detailed listing of all EFP input variables.

${ }^{13}$ In order to calculate average revenues the EFP will calculate revenue requirements and divide the result by total sales in kilowatthours.
} 
Information on firm interregional and international power transfers comes from the Electricity Capacity Planning (ECP) submodule.

Interest rates on bonds rated AA are passed to the EFP from the Macroeconomic Activity Module. These interest rates are used to determine the forecasted costs of capital in the EFP.

\section{Outputs}

There are also several outputs from the EFP which are passed to other NEMS components ${ }^{14}$. Electricity price forecasts by customer class are passed to the electricity demand modules. The demand modules use this price information to calculate changes in the demand for electricity.

The utility cost of capital is used by the Electricity Capacity Planning (ECP) submodule in its capital budgeting algorithm.

\footnotetext{
${ }^{14}$ Appendix $\mathrm{C}$ includes a detailed listing of all EFP output variables and their calculations.
} 


\section{Model Overview and Rationale}

\section{Theoretical Approach}

The EFP has four functions:

1. Electricity pricing,

2. Accounting,

3. Determining the cost of capital for electric utilities,

4. Determining the costs of transmission and distribution services.

The EFP is an accounting system that models regulatory practice and is completely deterministic. It has solution algorithms for the generation, transmission, and distribution stages of production. Pricing mechanisms are implemented for the generation and transmission stages of production to enhance the model's flexibility in simulating emerging pricing techniques used in the electric power industry. There are many pricing mechanisms that could be used for this purpose. The one that has been included initially in this submodule is the traditional cost of service method. The modular design of this submodule will allow the user to plug in additional pricing methods as they are needed in the future.

The first step in calculating generation and transmission transfer prices and distribution average revenues is the determination of the revenue requirement. The revenue requirement, the costs that a ratemaking authority allows a regulated utility to recover from ratepayers, is the sum of the fixed and variable costs of production. The fixed costs include the return on the ratebase, fixed operation and maintenance (O\&M) costs, and the annual depreciation expense (the recovery of invested capital). Revenue requirements are determined for generation, transmission, and distribution independently for each region. In the case of generation and transmission, the term revenue requirement is used loosely and is not meant to infer that, in the future, these stages are assumed to be regulated under a cost of selvice arrangement.

\section{Fixed Costs}

The ratebase is the total value (original cost less accumulated straight line depreciation and excluded tax deferrals) of all capitalized assets on which the regulated utility is allowed by a ratemaking authority to earn a return. The ratebase for the first modeled year is based on historical data from the previous year with additions or deletions determined by the modeled costs of capacity additions. Additions to the generation ratebase are determined in the Electricity Capacity Planning submodule. Transmission ratebase additions are determined in the EFP as a function of generation capacity expansion. Additions to the distribution ratebase are determined in the EFP as a function of sales. the EFP also determines the fixed O\&M for the three stages of production.

The forecasted rate of return is a function of the interest rate on AA rated utility bonds. This rate of return is the weighted average cost of capital for each region. In the first year of the simulation, the long-term debt rate for each region is the weighted average of the actual long-term debt rates for electric utilities in that region. After that it is a function of the national utility long-term debt rate (from the Macroeconomic Activity Module). The regional cost of equity is a function of the previous year's regional return on equity and debt, and the current year's regional debt rate. The cost of preferred stock is a function of the average of the regional debt rates. 


\section{Variable Costs}

Fuel costs and variable operation and maintenance costs (O\&M) for generation are determined by the Electricity Fuel Dispatch (EFD) submodule. Transmission and distribution related variable O\&M costs are determined in the EFP based on historic data as is the rest of the data for the calculation of the revenue requirements.

\section{Cost Allocation and Retail Average Revenues}

After the revenue requirements for all three stages of production have been aggregated, costs are allocated to the four customer classes. Costs are summed into four groups - capital related, fixed operation and maintenance (O\&M), variable O\&M, and fuel - for each stage of production for the purpose of allocation to customer classes. Several methods for allocating costs are available in the EFP. The choice as to which method to use for which type of costs (capital, fixed O\&M, variable O\&M, and fuel) for each stage of production is a user option.

The selection of the method used for the allocation of each type of cost (in each stage of production) should result in costs being allocated according to which customer class is responsible for the cost of service. For example, some costs, such as variable O\&M, can be confidently allocated on the basis of the level of electricity sales to each customer class. Others, such as fuel costs, are allocated on the basis of each customer class's contribution to the system peak load at the time of peak load (coincident peak method). The justification for this is that, for the purposes of allocating costs, it is assumed that electric utilities burn more expensive fuel as demand on the system increases. Therefore, the customer class most responsible for the system peak is most responsible for the burning of the most expensive fuels. Allocating fuel costs on the basis of the customer class's contribution to the peak load (using the coincident peak or probability of contribution to peak method) provides a method that is consistent with that assumption. Other costs, such as the cost of building new generating plants, are incurred to meet peak load requirements as well as for fuel diversity and other reasons. Allocation methods that recognize the multiple reasons for these costs have been developed in the utility industry and are available in the EFP (two versions of the average and excess demand method).

Following are the cost allocation methods available in the EFP:

Sales method. Costs are allocated on the basis of the proportion of electricity sales, in kilowatthours, to each of the four customer classes. This method will be used most frequently to allocate variable O\&M costs for all three stages of production (generation, transmission, and distribution).

Coincident peak method. Costs are allocated on the basis of each customer class's contribution to the system peak at the time of the system peak ${ }^{15}$.

\footnotetext{
${ }^{15}$ The system, or coincident peak, is the hignest point on the system load curve. That is where the greatest demand on the system exists. Non-coincident peaks, on the other hand, are where individual customer class demands are greatest.
} 
Probablitity of contribution to peak (PCP) method. The proportion of each class's load in each of the highest twenty peaking hours of each year (from the Load and Demand Side Management - LDSM submodule) is determined. Each customer class's proportions are averaged for each year and used as the weight for allocating costs. That is, costs are allocated on the basis of system peak data to time periods and customer classes.

Non-coincident peak (NCP) method. The residential, commercial, industrial, and transportation peaks are summed. Costs are allocated on the basis of the proportion of each customer class's individual peak load to the sum of the individual peak loads. This method will be used most frequently to allocate distribution fixed O\&M ano sapital costs, and will be used with the average and excess demand using probability of contribution to peak (AED-PCP) method (discussed below) to allocate transmission fixed O\&M and capital costs.

Average and excess demand method using the probability of contribution to peak (AED-PCP) or coincident peak (AED-CP). This cost allocation method recognizes that capital additions are not made solely for peak demands. Sometimes capital additions are needed for fuel cost savings or other sales oriented reasons. Customer class peaks and system load factors are both used in allocating costs. In this method costs are first divided into those that will be allocated on the basis of average demand and those that will be allocated on the basis of "excess" or peak load demand. Those costs to be allocated on the basis of average demand are allocated first. This is done by calculating the ratio of the class average demand to the sums of the class average demands. Then, the remaining costs are allocated on the basis of the demand in excess of the system load factor. This is done by calculating each customer class's contribution to the system peak using either the probability of contribution to peak method or the coincident peak method.

Retail electricity average revenues are calculated for each ownership type (investor owned and public utilities) and across ownership categories (investor owned and public utilities combined) for each NERC region and selected subregions. That is, each region will have an average revenue calculation for investor owned utilities, public utilities, and a combination of the two. The calculation of average revenues for a given region and customer class is the revenue requirement that has been allocated to that customer class divided by the total sales (kilowatthours) to that customer class, or:

Average Revenue $_{i j}=$ Total Revenue $_{i j}$ / $_{\text {Sales }_{i j}}$ where:

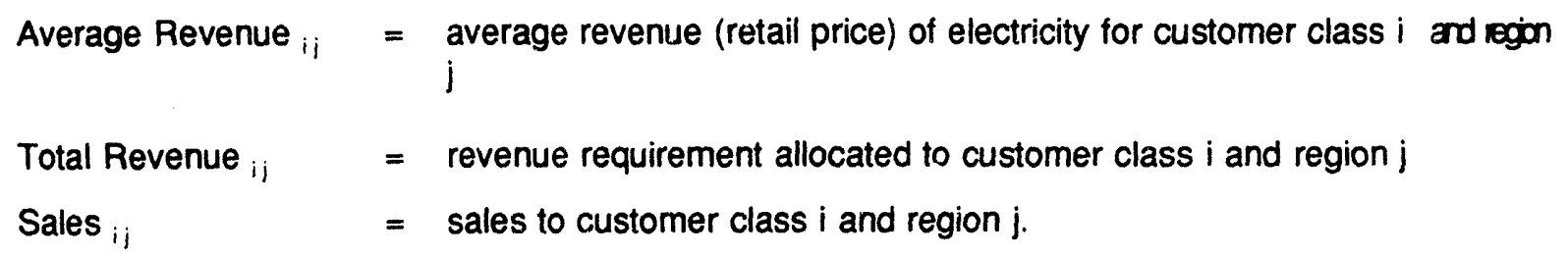

Stage of production and industry-wide financial statements are generated for each region and nationally. Financial statements are standard accounting statements such as Baiance Sheets and Income Statements. The industry-wide financial statements aggregate the three stages of production into a single set of financial 
statements to represent a vertically integrated industry.

\section{Fundamental Assumption}

The fundamental assumption is that standard cost of service regulation will continue. That is, utilities will recover their expenses plus a return on their investments equal to their cost of capital.

\section{Alternative Approaches and Reasons for Selection}

The National Utility Financial Statements model (NUJS) is the predecessor to the EFP as the financial and electricity pricing component of ElA's intermediate term energy modeling system. The EFP replaces NUFS to account for two broad based changes in the industry that are occurring or could occur in the next decade. These two changes are: (1) industry structural changes, and (2) capital investment changes.

\section{Changes Related to Industry Structure}

The structure of the electric power industry today, in which vertically integrated franchise monopolies ${ }^{16}$ dominate, was influenced in large part by the Public Utility Holding Company Act of 1935 (PUHCA). This act was passed by Congress as part of the New Deal legislation to break up the large monopoly holding companies that dominated the electric power industry. These holding companies were structured in such a way as to impede regulatory oversight.

This vertical integration of the electric power industry may be breaking down as a result of policy initiatives such as reform of the PUHCA and efforts to increase competition in the power generation arena to increase efficiency by encouraging the emergence of nonutility generators. In many cases, wholesale rates for nonutility generators are set by means other than the traditional cost of service approach. Competitive bidding and other mechanisms that produce market based rates ${ }^{17}$ are currently being used by regulated utilities to select nonutilities (NUGs) as suppliers of wholesale power.

As a result of this potential disintegration ${ }^{18}$, separate companies working within distinct regulatory frameworks could be involved in each of the three primary stages of production of the industry: generation, transmission, and distribution ${ }^{19}$. Therefore these three stages of production are modeled separately. Transfer prices are calculated for generation and transmission. The purpose of these transfer prices is to

\footnotetext{
${ }^{16}$ In a franchise monopoly, an electric utility (investor-owned or public) operates in a defined service territory at the exclusion of all other electric utilities.

${ }^{17}$ The term, market based rates, is a general term here that refers to prices established in whole or part by market transactions. Examples include competitive bidding by IPP's to build and operate generating capacity and price caps set by the Federal Energy Regulatory Commission (FERC) for wholesale electricity rates.

${ }^{18}$ Vertical disintegration and unbundling are syrionymous terms.

19 Within each stage of production - generation, transmission, and distribution - representations are made of the various ownership categories, regulatory considerations, and economic assumptions that exist now or are likely to exist in the future.
} 
transfer the costs of each of these stages to the distribution stage so that total costs for all of these stages can be included in the calculation of average revenues. In the case of a vertically integrated electric utility, the generation and transmission transfer prices represent the flow of costs (as between divisions within a corporation) that become components of the retail pricing mechanism (which calculates average revenues for distribution). This technique will facilitate an analysis of industry structural change, allow for independent assumptions for each of the three stages of production with regard to regulatory and tax treatment, and will allow the analyst to use a variety of costing mechanisms with varying underlying economic assumptions for these stages of production.

Separate financial statements are provided for each of these stages of production on a regional and national basis so that an independent analysis of each will be feasible. (Financial statements are provided on an industry-wide basis as well. In these reports, the three stages of production are combined at the regional and national levels to represent a regional vertically integrated utility.)

The pricing technique used for retall distribution continues to be the average cost based method used by NUFS. An assumption of the EFP is that retail electricity rates will continue to be regulated on a cost of service basis. Average revenues continue to be calculated for the four customer classes represented in NUFS: residential, commercial, industrial, and transportation. An improved cost allocation algorithm has been implemented so that these customer class average revenues are more meaningful in terms of the actual forecasted cost of service. That is, cost allocation methods in the EFP may use peak load data generated by the Load and Demand Side Management submodule (LDSM) as the basis for the allocation of some costs of service so that costs may be more accurately allocated to the customer class responsible for those costs.

\section{Changes Related to Capital Expenditures}

The second broad based change has to do with investment emphasis. In the 1970's and 1980's, most capital expenditures were for construction projects. However, over the next ten years, a sizable amount of capital expenditures will be for purposes other than for new construction. They include demand side management (DSM) costs, nuclear decommissioning costs, life extension costs, post operational capital expenditures, and costs and revenues associated with the Clean Air Act Amendments of 1990 (CAA). Since many of the accounting and rate-making issues dealing with these expenditures will be different in the future, the EFP is designed so that an accurate representation of these issues can be made.

Cost and performance information for DSM programs will be developed in the Load and Demand-Side Management Submodule of the EMM in NEMS while their penetration and impacts will be represented in the individual demand models. The EFP accounts for these direct costs, whether expensed or capitalized, and includes them in the pricing function. In the electric power industry, it is necessary to compensate utilities for the reduction in revenues that results from DSM programs through revenue adjustment mechanisms because the rates that they charge are based on historic test periods that reflect a higher demand for electricity. Lost revenues (and profits) which can result from utility investments in DSM programs are captured in the EFP because it calculates average revenues (prices) based on demand after adjustment for DSM impacts. The EFP is also able to capture the adjustments to allowed rates of return that some states are offering to utilities as incentives for implementing DSM programs through adjustments to the model's return on equity component of average revenues.

Several other electric utility models that contain a financial component have been examined:

Electricity Finance and Pricing Submodule Documentation - April 1994 
- Electric Generation Expansion Analysis System (AGEAS), from the Electric Power Research Institute (EPRI) and Stone and Webster

- Load Management Strategy Testing Model (LMSTM), Version 4.0, from EPRI and Electric Power Software, Inc.

- Integrated Utility Planning and Analysis System (PROSCREEN II), from Energy Management Associates, Inc.

- Integrated Utility Planning System (UPLAN III), from LCG Consulting

- Electric and Gas Utility Modeling System (EGUMS), from RCG/Hagler, Bailly, Inc.

\section{Model Usage}

The most important consideration that must be made in a comparison of the capabilities of these models to the capabilities of the EFP is that, with the exception of EGUMS, these models are designed to represent the operations of a single utility. This is significant because a single utility model can incorporate very specific information about accounting practices and load characteristics that an aggregate model does not have. There are two issues where this becomes manifest. First, the single utility model is capable of using very specific information concerning customer load characteristics in allocating costs to customer classes. The EFP uses less detailed aggregate customer load data that covers an entire NERC Region instead of just a utility service area. Second, a single utility model can take advantage of utility-specific data in its determination of marginal costs. In particular it has available to it refined data on (1) the probability of a given generating unit being the marginal unit of production, (2) the variable costs of generation for specific generating plants, as opposed to aggregate data on the typical generating plant of a specific type that must be used in an aggregate model, and (3) customer load characteristics.

While EGUMS is an aggregate model, its purpose is entirely different from that of the EFP. The EFP is designed for policy analysis and forecasting for a broad range of regulatory and legislative possibilities, and must be very flexible with many policy handles ${ }^{20}$. EGUMS is designed specifically to aid in the analysis of the role that demand side management (DSM) can play in pollution abatement. EGUMS will not be used in the analysis of regulations dealing with taxes, financial management, or accounting so it does not need the explicit revenue requirement calculation, phase-in, sale-leaseback, and disallowance capabilities that are required of the EFP. EGUMS calculates marginal energy and capacity costs for use by the DSM algorithm, but it has no need for the transfer prices that will be used by the EFP. It also uses a fixed shares algorithm for allocating costs to the various customer classes.

\section{Revenue Requirements}

LMSTM, PROSCREEN II, and UPLAN III all use a detailed calculation of revenue requirements in much the same way as the EFP. The ratebase and expenses are calculated to determine the revenue requirements. PROSCREEN II and UPLAN III use an iterative process, adjusting the revenue requirements

\footnotetext{
${ }^{20} \mathrm{~A}$ policy handle is a point in the model's code where changes in assumptions may be inserted. These assumption changes could be of a financial, regulatory, tax, industry, or political nature. This policy handle feature is a primary purpose for the National Energy Modeling System.
} 
up or down until user specified criteria have been reached. This change in revenue requirements corresponds to a rate case where a rate change has been approved. The decision criteria could be a specified return on common equity, a return on the ratebase, or other measures. The EFP does not explicitly model rate cases because it is a regional model instead of single utility model. An exception to this is that rate case decisions that include phase-ins or disallowances are modeled in the EFP if there is a significant impact on revenues at the regional level.

EGEAS uses customer rates to determine total revenues. It minimizes total revenue requirements subject to a capacity expansion plan in much the same fashion as the EFP. However, in EGEAS, all of the nongeneration costs for the utility are user inputs.

\section{Cost Allocation}

In the LMSTM, generation and distribution capacity revenue requirements are distributed to customer classes and rating periods using a percent-of-peak load allocation mechanism. The model allocates the revenue requirements to each kilowatt served in a manner such that the amount allocated is dependent on the fraction of the load in the hour divided by the load in the peak hour. As in the EFP, all assets and costs are assigned to functional categories (generation, transmission, and distribution). There is a rates submodule in which the user indicates the method for allocating costs in each functional category to customer classes (the user inputs a rate schedule) which indicates a customer, demand, and energy charge.

In PROSCREEN II, the user classifies costs into demand, customer, and energy components and a rate schedule is input into the model. One or more rate classes may be defined with others allowed to "float" to achieve a target retum. Several allocation methods are available including coincident peak demarid, noncoincident peak demand, average and excess demand, kilowatthour energy sales, number of customers, and weighted number of customers. Options are available to simulate dynamic forces and to equalize the calculation of total revenues to the sum of revenues for each customer class. These options include:

- revenue requirements equal the class cost of service including a specified rate of return on the ratebase, which may vary by class;

- same as above except there are class specific caps expressed as a multiple of the average percentage increase with the revenue in excess of the cap allocated to other classes;

- specific user input percentage increases by class;

- specific user supplied rates.

in UPLAN III end use prices are calculated to include both time-differentiated and non time-differentiated rates for up to twelve customer classes. Rates are generated by customer classes for peak, off-peak, and shoulder hours. In AGEAS input customer class rates are altered if one class's revenues are reduced by a DSM program. In this scenario, the other classes subsidize the fixed costs previously allocated to that class. In the EFP, costs are allocated after the effects of all DSM programs have been identified in terms of the cost of service, clistomer class average demands, and customer class load shapes. 


\section{Market Based Rates}

Both LMSTM and UPLAN III expressly model market based rates. LMSTM uses an override feature which bypasses the cost of service calculation. Instead, the model uses a rate input by the user; either an absolute price per kilowatthour or annual escalation. UPLAN III calculates an hourly rate and cost that are set as the purchase price for energy and capacity by a grid company or by the dispatcher of a pool organization. The calculation of the hourly rate is based on the specifications for the United Kingdom grid policy:

Rate = Marginal Energy Cost + LOLP * Value of Capacity + Other Costs

Marginal Energy Cost: the highest incremental cost of any unit operating in any particular hour

LOLP: the loss of load probability as calculated based on the reliability in any hour

Value of Capacity: the difference between the value of the lost load and the marginal cost. Set to zero if the number is negative.

Other Costs: Any other economic parameter set by the user. 


\section{Model Structure: \\ Data Flow Diagram}

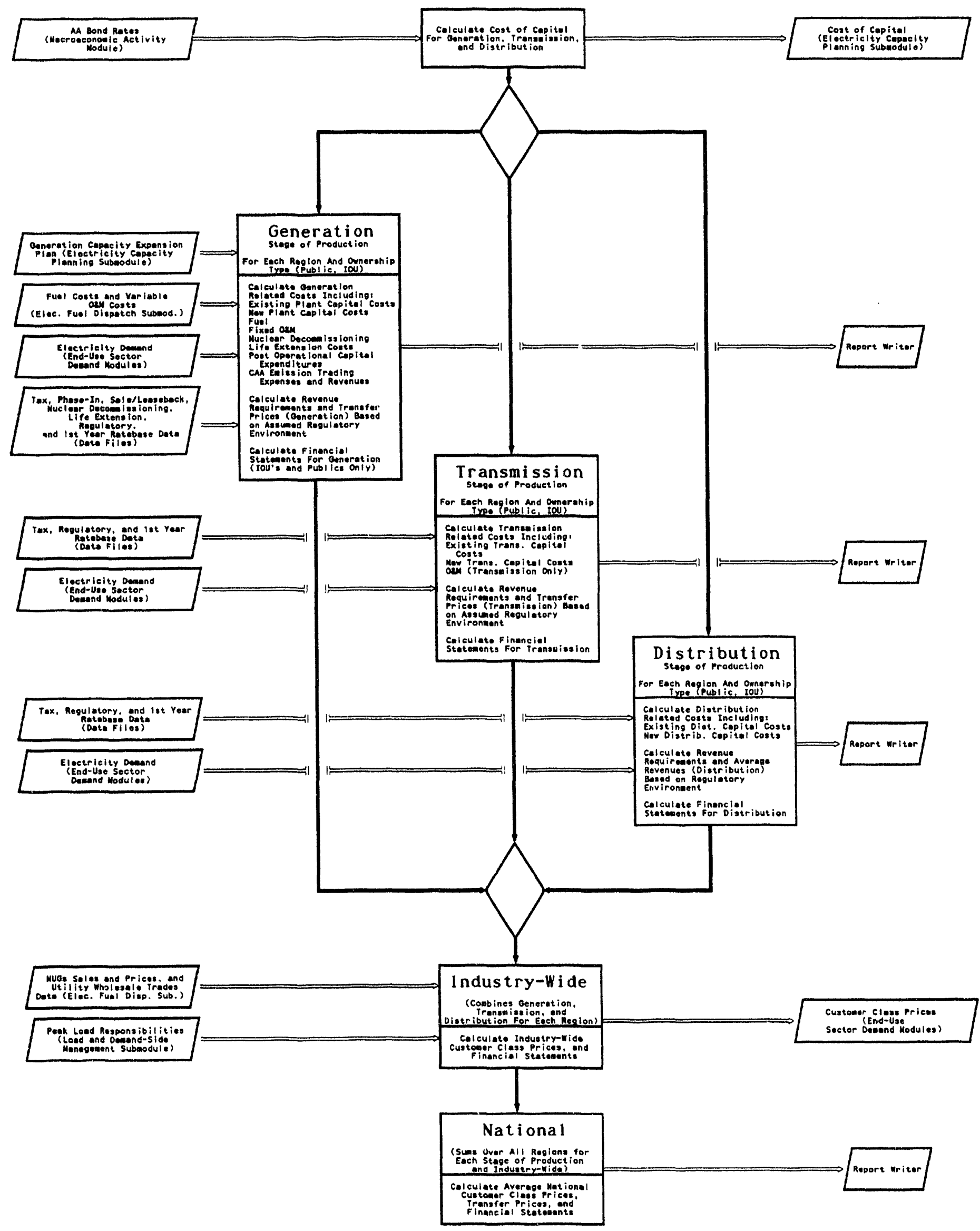




\section{Solution Algorithm and Key Computations}

\section{Overview}

The purpose of this chapter is to describe the solution algorithm used within EFP. The discussion in this chapter is organized into two sections. The first section, 1 . Forecasting Revenue Requirements, describes the method used to forecast annual revenue requirements. In order to forecast the revenue requirement, one must first forecast the components of the rate base and the expenses. This section will describe the algorithms used to calculate and forecast these items. With all of these items forecast, one has nearly all the necessary components to forecast the financial statements and ratios. The second section, 2 . Remaining Algorithms, describes the process of using these items to yield forecasts of electric revenue, prices, taxes (both actual and for financial purposes), and financial ratios.

\section{Forecasting Revenue Requirements}

The EFP method of forecasting revenue requirements duplicates the regulatory process. The EFP forecast of revenue requirements in any given year is that which allows the utilities to earn a rate of return equal to the cost of capital and also recover their operating costs. Formally, the forecast for revenue requirements in any given year is:

$$
\begin{aligned}
\text { ERRVRQ = } & (\text { ERRB * ESRR })+\text { ERTFLN + ERTOMN + ERBDE + GENREG + STAREG + } \\
& \text { FEDREG - EROFFS + ESLLPN - EPIND }
\end{aligned}
$$

where:21

$\begin{array}{ll}\text { ERRVRQ } & =\text { revenue requirement } \\ \text { ERRB } & =\text { rate base } \\ \text { ESRR } & =\text { rate of return } \\ \text { ERTFLN } & =\text { fuel costs } \\ \text { ERTOMN } & =\text { operation and maintenance expenses, excluding fuel costs } \\ \text { ERBDE } & =\text { book depreciation expense } \\ \text { GENREG } & =\text { general taxes (gross receipts, property, sales) for regulatory purposes } \\ \text { STAREG } & =\text { State income taxes for regulatory purposes } \\ \text { FEDREG } & =\text { Federal income taxes for regulatory purposes } \\ \text { EROFFS } & =\text { AFUDC offset }\end{array}$

21 The variable names used in this description are the same as those found in the computer code of EFP. There are some conventions used in variable naming, as follows. A prefix of ER denotes variables containing results aggregated to the total system level. A prefix of ES denotes a ratio or fraction. A prefix of EO denotes variables related to assets existing before the first forecast year. Finally, a prefix of EB denotes a variable related to an individual plant build.

22 For accounts that describe flows' (e.g., fuel expense, depreciation expense), the value refers to the period January 1 to December 31 of the given year. For accounts that describe 'stocks' (e.g., rate base, utility plant), except when otherwise stated, the value refers to the end of the given year value, i.e., value on December 31 of the given year. 
ESLLPN = net lease payment associated with sales/leaseback transactions EPIND $=$ net deferred phase-in revenues for year.

Note that, except where specifically stated, the variables are calculated in nominal dollars. Nominal dollars, rather than real dollars, are required to simulate the regulatory process effectively. Once nominal electricity prices are determined, they are reported in both nominal and real dollars. Each of the eleven variables on the right-hand side of the revenue requirement equation above is discussed in separate sections labeled 1.1 through 1.11. More detailed and involved discussions are needed to fully describe the solution algorithms. To aid in the continuity of this presentation, these discussions are separated into their own sections and are labeled 1.12 through 1.17. The discussions in Sections 1.1 through 1.11 sometimes refer to these later sections.

\subsection{Calculation of Rate Base (ERRB)}

The formula used to calculate the rate base is:

ERRB = ERTUP + ERRCWP + ERWC + ERNFSN - ERABDE - ERPRDF - (ERCNBV ERCNAD) - ESLNDG - EDISNT

where:

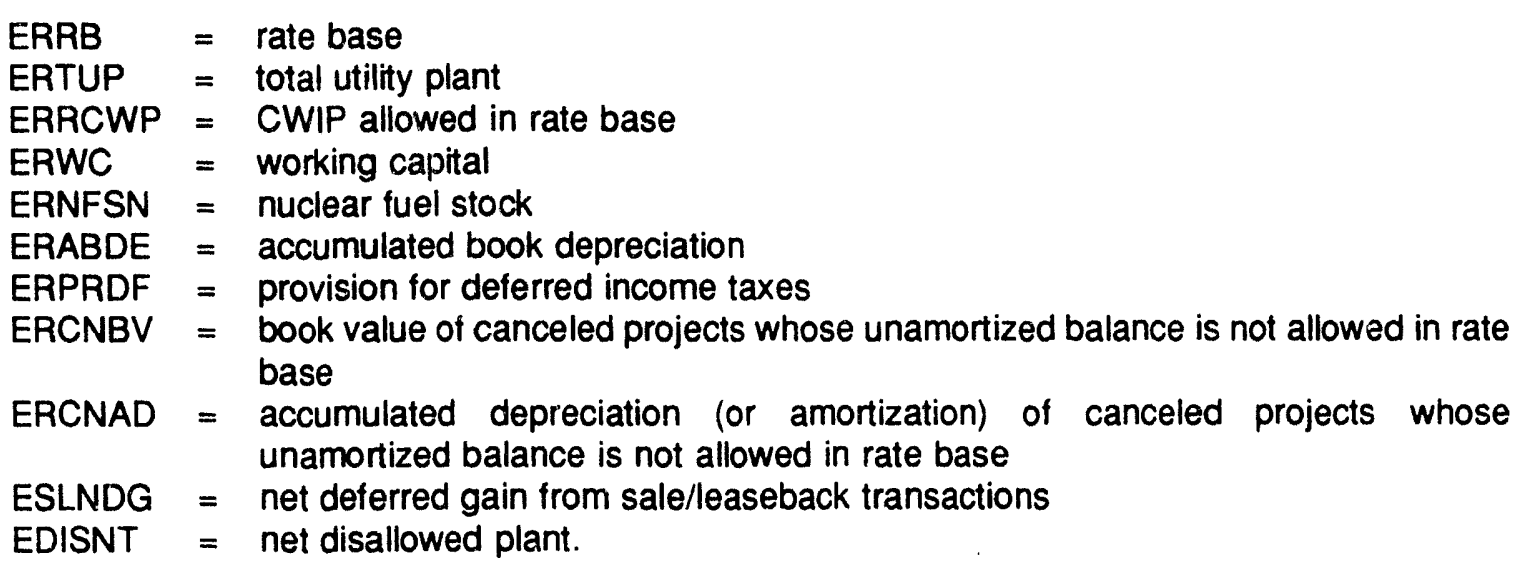

As calculated above, ERRB is the year-end rate base. Another option in EFP is to calculate revenue requirements using the average value of the rate base over the year. The analyst may choose either option. The formulas used to calculate the average rate base are:

$$
\begin{aligned}
& \text { ERRBAQ }=(\text { ERRB }+ \text { ERRBB }) / 2.0 \\
& \text { ERRBB }=\text { ERRB }_{t-1}+\text { ERDLRB }
\end{aligned}
$$

where:

$$
\begin{aligned}
& \text { ERRBA = average year rate base } \\
& \text { ERRB = end of year rate base } \\
& \text { ERRBB = beginning year rate base } \\
& \text { ERRB }_{t-1}=\text { end of year rate base from proceeding year } \\
& \text { ERDLRB = book value of new plants that come on line this year. }
\end{aligned}
$$


The average-year rate base is calculated as the simple average of the beginning-and end-ot-year rate base. The beginning-of-year rate base is calculated as the rate base at the end of the previous year plus the book value of any new plants that come on line in the given year. (The calculation of the book value of new assets is described in Sertion 1.13)

When the end-of-year rate base option is chosen, an additional adjustment to the valculation of rate base is made. When plants come on line in the middle of a given year, they continue to accrue AFLDC for those months until the plant is actually in service. To avoid earning an excess return (AFUDC plus a fullyear cash return) on such plants, the end-of-year rate base is lowered so that the total return (AFUDC plus cash return) on the plant is appropriate.

The values of ERCNBV and ERCNAD are calculated by summing the costs of all canceled projects. For projects canceled before the first year of the forecast horizon, the costs are specified by the analyst through inputs. For projects canceled after the first year of the forecast horizon, the analyst specifies which projects are to be canceled and at what point in time, and the costs of the projects are based on costs incurred up to the cancellation date (as simulated within the model).

ERRCWP is discussed in Section 1.13. ERABDE and ERPRDF are discussed in Section 1.14. ESLNDG is discussed in Section 1.16. EDISNT is discussed Section 1.17. Each of the remaining components of the rate base equation is discussed below.

\section{1-a Total Utility Plant (ERTUP)}

Total Utility Plant (ERTUP) is calculated as:

$$
\text { ERTUP }=\sum_{\text {all } k}\left(E O B K V L_{k}\right)+\sum_{\text {all } k}\left(\text { ERBVYE }_{k}\right)-\text { ERBTIR }
$$

where:

$$
\begin{aligned}
& \text { EOBKVL }=\begin{array}{l}
\text { book value of assets existing in the base year (old assets) of type } k \text { (i.e., } \\
\text { distribution) }
\end{array} \\
& \text { ERBVYE } E_{k}=\begin{array}{l}
\text { book value of assets completed in the forecast horizon (new assets) of type } k \\
\text { which are completed as of the year of forecast }
\end{array} \\
& \text { ERBTIR }=\begin{array}{l}
\text { book value of all assets which have been retired during the forecast horizon as of } \\
\text { the year of forecast. }
\end{array}
\end{aligned}
$$

The book value of existing assets in the base year is an input that can be derived from historical financial statements such as the FERC Form 1 or Form EIA-412. The calculation of ERBTIR is discussed in Section 1.14. ERBVYE $E_{k}$ is calculated by summing the book values of each individual new asset of type $k$ which is completed as of the year of forecast. The calculation of the book value of individual new assets is discussed in Section 1.13.

\section{1-b Working Capital (ERWC)}

Working capital is calculated within EFP using what is known as the $1 / 8$ method. In general, this method arrives at working capital by summing the following: materials and supplies excluding fuel stocks; a percentage of operating and maintenance expenses, usually $1 / 8$, representing a 45 -day net lag in revenues and expenses; and other adjustments unique to a jurisdiction. The $1 / 8$ method is based on the assumption 
that an average monthly billing utility has a net lag of 45 days between the payment of expenses and collection of revenues. This method of estimating working capital does have some drawbacks. The implicit assumption behind the $1 / 8$ method is that there is a positive working capital need. The $1 / 8$ method does not give any recognition to the availability of working capital resulting from the accrual of interest or tax expenses prior to the time of their payment. Items such as these constitute sources of working capital that are not considered using the 1/8 method. In addition, under circumstances of unusually fast receipt of customer payments and extended delay in paying suppliers, there can actually be a negative working capital requirement for a utility. The $1 / 8$ method also assumes that all utilities have the same experience with regard to receipt of payment from customers and employ the same payment policies.

The calculation for working capital is:

ERWC $=.125^{*}$ (ERTOMN + ERTFLN)

where:

ERTOMN = operation and maintenance costs, excluding fuel

ERTFLN = fuel costs

The calculation of ERTOMN is discussed in Section 1.4. ERTFLN is discussed in Section 1.3.

\section{1-c Nuclear Fuel Stock (ERNFSN)}

The nuclear fuel stock in any given year is calculated as a function of the amount of fuel actually used in the year.

ERNFSN $=3.5^{*}$ EFPNUC * ESGNPD

where:
ERNFSN $=$ Nuclear fuel stock
EFPNUC $=$ Real dollar nuclear fuel expense
ESGNPD = inflation index to convert real dollars to nominal dollars

\subsection{Rate of Return (ESRR)}

The rate of return is calculated as a weighted average of the cost of long term debt, short term debt, common equity, and preferred stock. The equation is:

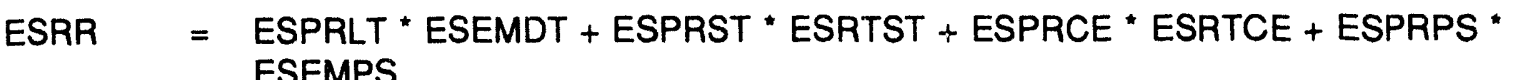

where:

ESPRLT $=$ fraction of capital structure made up by long term debt
ESPRST $=$ fraction of capital structure made up by short term debt
ESPRCE $=$ fraction of capital structure made up by common equity
ESPRPS $=$ fraction of capital structure made up by preferred stock
ESEMDT $=$ embedded cost of long term debt
ESRTST $=$ cost of short term debt


ESRTCE = allowed return on common equity

ESEMPT = embedded cost of preferred stock.

With the exception of ESEMDT, ESEMPT, and ESRTCE all of the above values are inputs into EFP.

\section{2-a Embedded Cost of Long Term Debt (ESEMDT)}

The embedded cost of long-term debt in any year is a function of several quantities including the cost of new debt, the cost of existing debt, and the timing and quantity of retirements and issues of new debt:

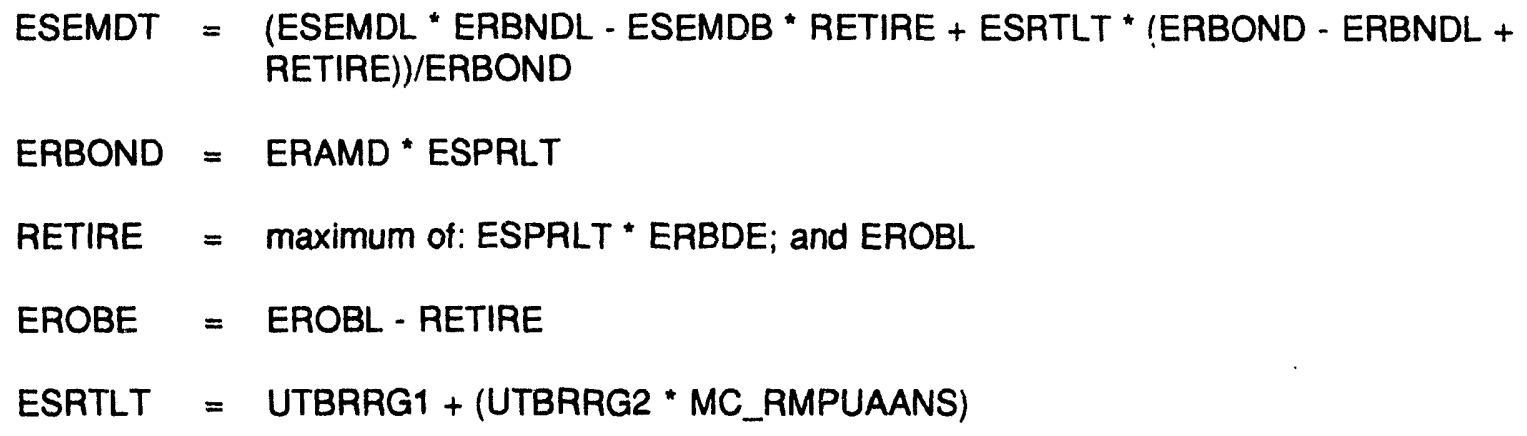

where:

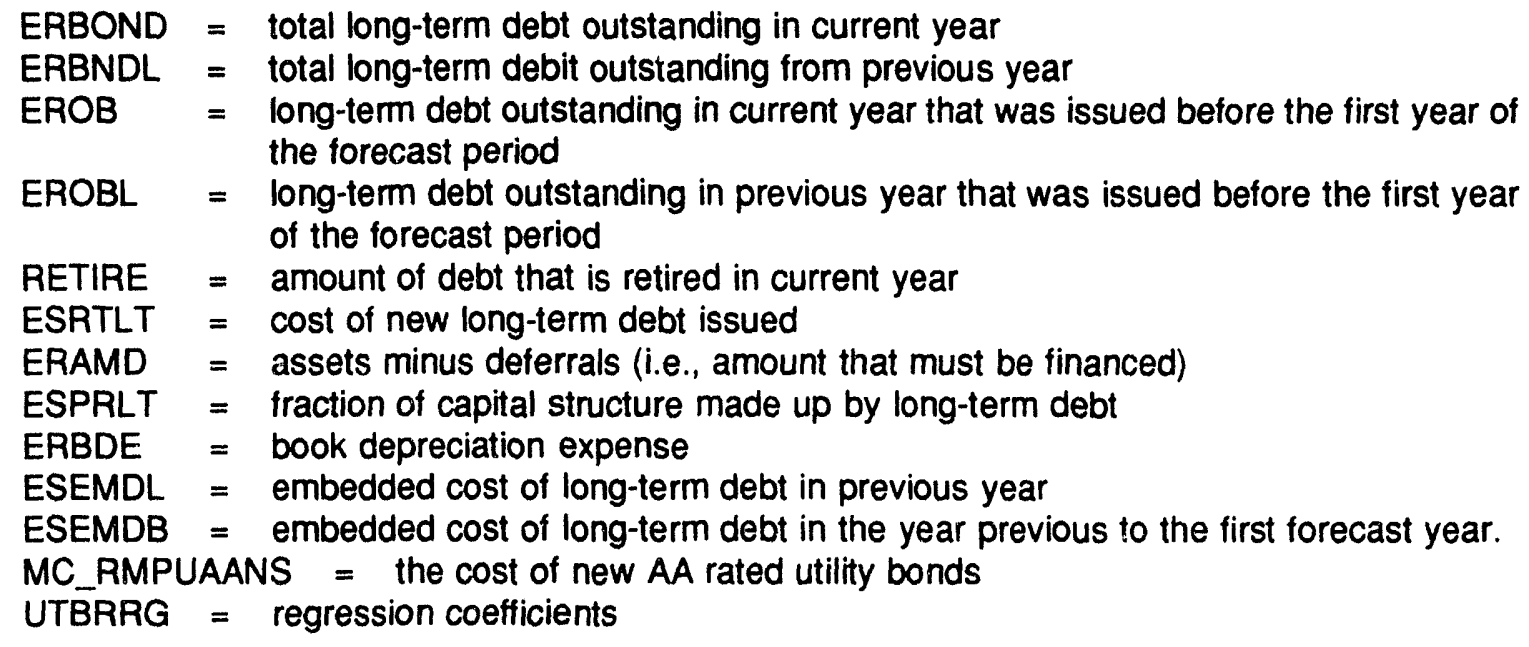

The algorithm calculates the embedded cost of debt as a weighted average of: i) the embedded cost in the previous year (ESEMDL); ii) the embedded cost in the base year (ESEMDB); and iii) the cost of new long term debt issued in the current year (ESRTNB). Only debt issued before the forecast period is assumed to be retired. This is appropriate, given the mid-range forecast period over which EFP forecasts. EROBL for a given year is equal to EROB from the previous year. ESRTNB, ESEMDB, EROBL (for first forecast year), and ESPRLT are user inputs in this algorithm. ERAMD and ERBDE are discussed in Sections $1.7-b$ and 1.14 , respectively. 


\section{2-b Embedded Cost of Preferred Stock (ESEMPS)}

The embedded cost of preferred stock is calculated in an algorithm similar to that used for the embedded cost of long-term debt above.

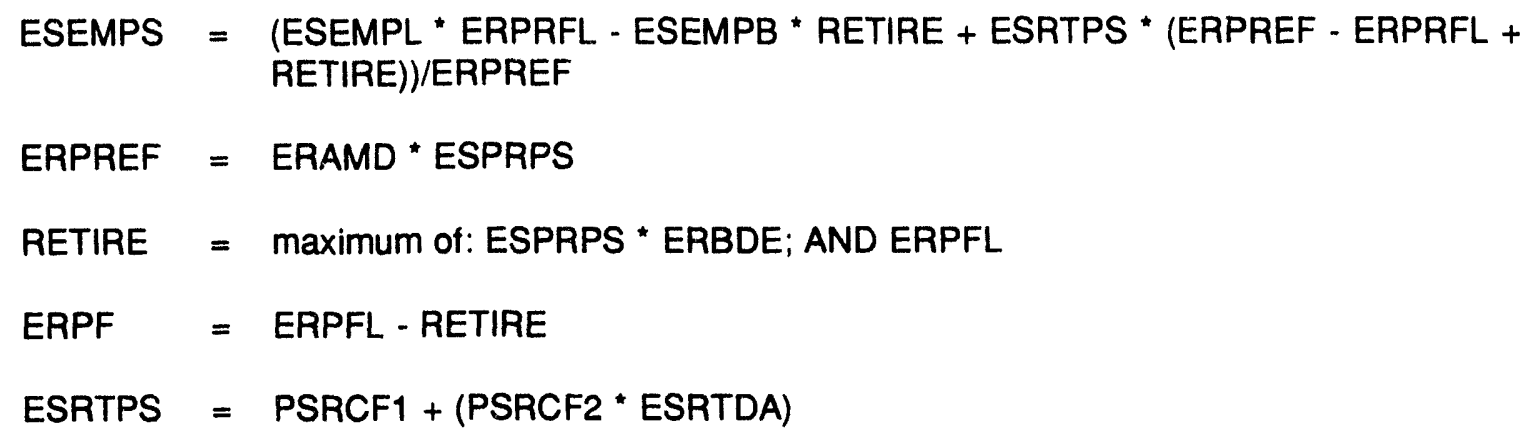

where:

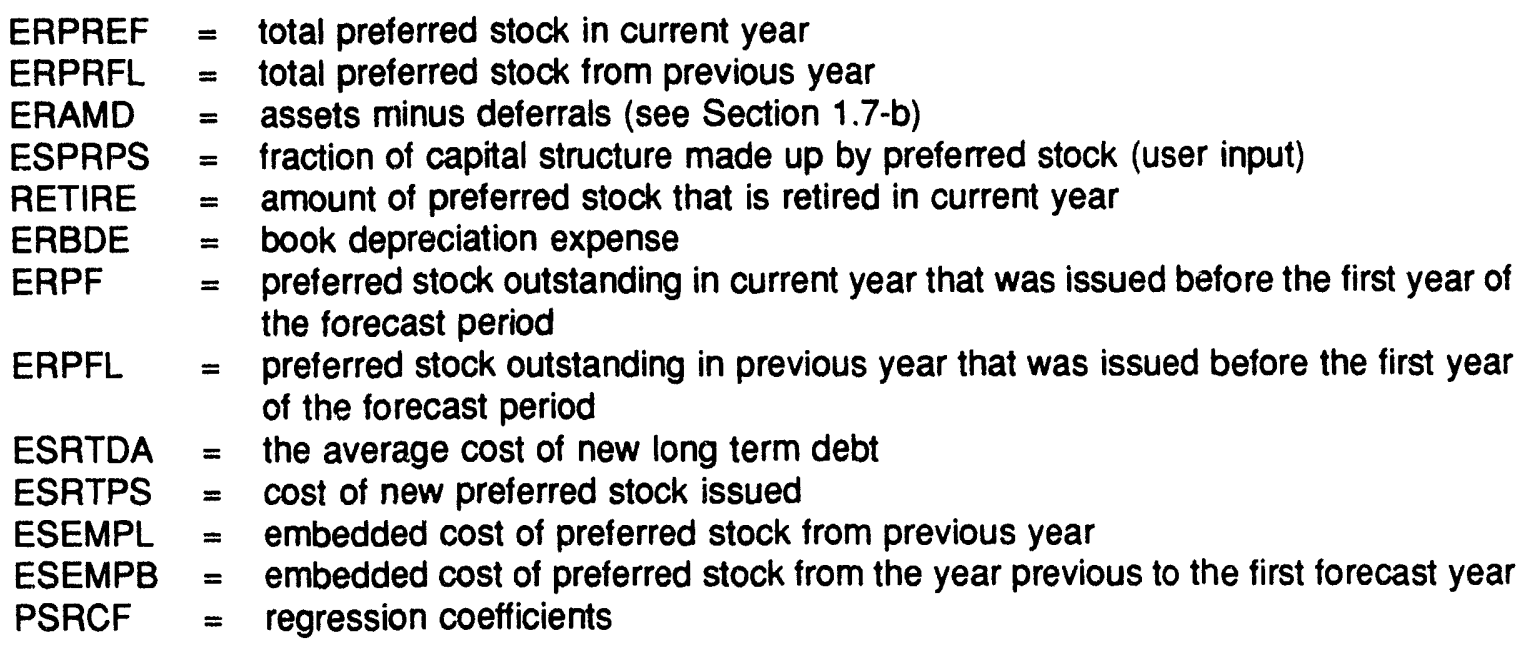

ERPFL for a given year is equal to ERPF from the previous year. The values of ESEMPB and ERPFL (for the first forecast year) are input into EFP. These values can be derived from historical financial statements such as the FERC Form 1.

\section{2-c Cost of Common Equity (ESRTCE)}

The cost of common equity is a function of the previous year's cost of equity, the cost of new long term debt, and the cost of new debt in the previous year:

$$
\text { ESRTCE = ARRCF1 + (ARRCF2 * ESRTCL })+(\text { ARRCF3 * ESRTLT })+(\text { ARRCF4 * ESRTDL })
$$

where:

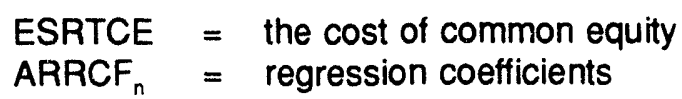


ESRTCL $=$ the cost of equity in the previous forecast year

ESRTLT = the cost of new debt

ESRTDL = the cost of new debt in the previous forecast year

\subsection{Fuel Costs (ERTFLN)}

Fuel costs in each forecast year are derived from the results of the dispatch exercise.

$E R T F L N=(E F P F L+B L K S U M) * E S G N P D$

where:
ERTFLN $=$ nominal dollar fuel cost
EFPFL = real dollar fuel costs as determined by the dispatch model
BLKSUM = real dollar wholesale purchase costs (includes imports, exports, purchases from NUGs and inter-regional transfers) determined by the dispatch model
ESGNPD = inflation index to convert real dollars to nominal dollars

\subsection{Operation and Maintenance (O\&M), Excluding Fuel (ERTOMN)}

As with fuel costs, operation and maintenance costs are input to EFP from other modules being used to drive EFP. Again, if necessary, these costs are inflated each year by a user-defined inflation rate. Operation and maintenance costs are calculated differently for generation, transmission, and distribution.

\section{4-a Generation O\&M}

$E R T O M N=(E R T O M+O V E R P R+E R T O M F+O M L E) * E S G N P D$

where:
ERTOM
$=$ real dollar production related variable operation and maintenance expenses
ESGNPD
$=$ inflation index to convert real dollars to nominal dollars.
ERTOMF
= real dollar production related fixed $O \& M$ expenses
OVERPR
$=$ real dollar production and maintenance expenses allocated to the production function. (eg. general and administrative)
OMLE = real dollar $O \& M$ expenses associated with the life extension of the generating units

\section{4-b Transmission O\&M}

$E R T O M N=(E R T O M T+$ OVERTR $) *$ ESGNPD

where:

ERTOMT = real dollar transmission operation and maintenance expenses

ESGNPD = inflation index to convert real dollars to nominal dollars.

OVERTR = real dollar overhead-related $O \& M$ expenses allocated to transmission. (eg. general administration). 


\section{4-c Distribution O\&M}

Operation and maintenance costs are input to EFP from the distribution model being used to drive EFP. If necessary, these costs are inflated each year by $a$ user-defined inflation rate.

ERTOMN $=($ ERTOMD + OVERDS $) *$ ESGNPD

where:

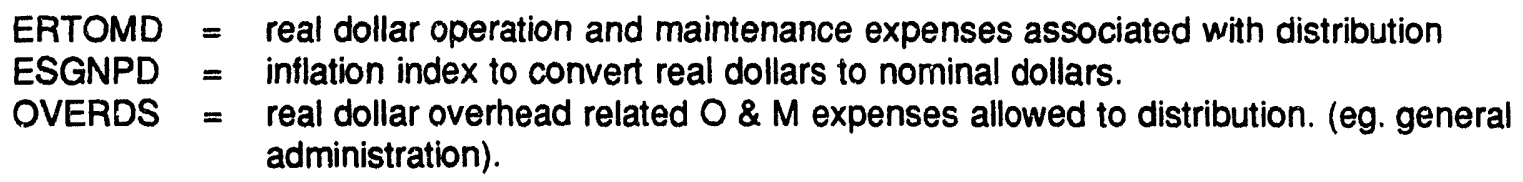

\subsection{Depreciation (ERBDE)}

Discussion of the book depreciation expense may be found in Section 1.14.

\subsection{General Taxes for Regulatory Purposes (GENREG)}

General taxes encompass all taxes except State and Federal income taxes. Among these taxes are gross receipts, FICA, payroll, property, and sales.

It is assumed that these taxes each year will be a constant percentage of revenue requirements.

GENREG = EGTXRT * ERRVRQ + ERPRTX + ERSLTX

where:

EGTXRT $=$ gross receipts tax rate
ERRVRQ $=$ revenue requirement
ERPRTX $=$ property taxes
ERSLTX $=$ sales tax

The gross receints tax rate is an input which is calculated from base-year data (e.g., FERC Form 1, Form EIA-412). Including ERRVRQ on the right-hand side of the equation appears to make this discussion circuiar (i.e., ERRVRQ is a function of GENREG and GENREG is a function of ERRVRQ). This is resolved in Section 1.12.

ERPRTX is mndeled as an input fraction of book value and ERSLTX is modeled as an input fraction of construction expenditures.

\subsection{State Income Taxes for Regulatory Purposes (STAREG)}

STAREG is equal to State taxable income for regulatory purposes multiplied by the State income tax rate:

STAREG = (ERRVRQ - ERTFLN - ERTOMN - ERTDWO - ERTIEX - ESLLP) * ESSTXR

where: 


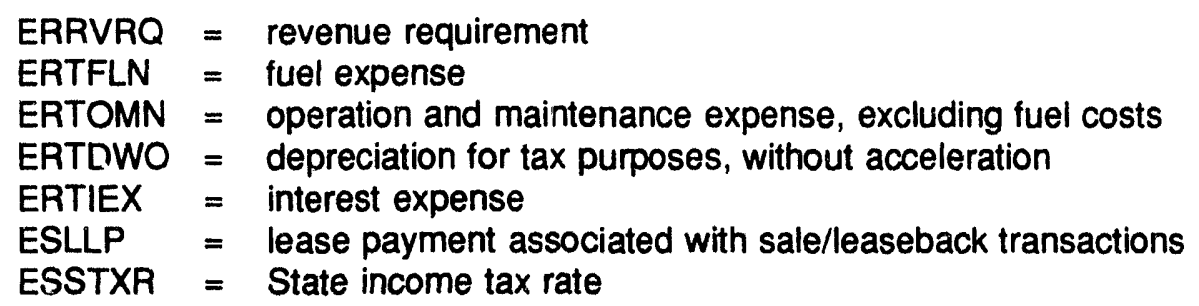

ERRVRQ on the right-hand side of this equation is discussed in Section 1.12. ERTFLN and ERTOMN were discussed in Sections 1.4 and 1.4, respectively. ERTDWO is discussed in Section 1.14-b. ESLLP is discussed in Section 1.16. ESSTXR, is a user input. ERTIEX is now discussed.

\section{7-a Interest Expenses (ERTIEX)}

The total interest expense depends on the cost of debt and on the average amount of debt outstanding during the year.

$$
\begin{aligned}
& \text { ERSIEX }=\text { ESRTST * ESPRST * (ERAMD + ERAMDL - ESLPRC) } \\
& 2 \\
& \text { ERLIEX }=\text { ESEMDT * ESPRLT * (ERAMD + ERAMDL - ESLPRC) } \\
& \text { ERTIEX }=\text { ERSIEX + ERLIEX }
\end{aligned}
$$

where:

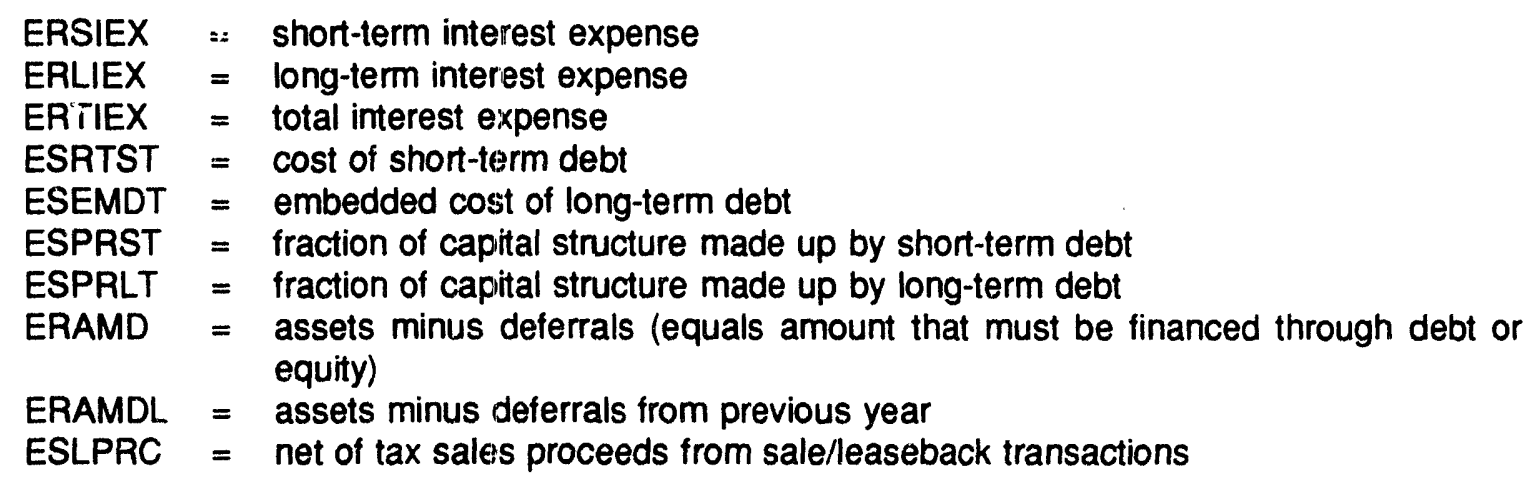

ESRTST, ESPRST, and ESPRLT are user inputs. ESEMDT was discussed in Section 1.2-a. ERAMDL for a given year is equal to ERAMD from the previous year. ERAMD is discussed below. ESLPRC is discussed in Section 1.16.

\section{7-b Assets Minus Deferrals (ERAMD)}

ERAMD is the amount that must be financed by debt or equity.

$$
\begin{aligned}
\text { ERAMD = } & \text { ERTUP + ERIBCWP + ERWC + ERNFSN + EPIDEF - ERABDE - ERPRDF - } \\
& \text { ERDITC - EDISNT - ESLNDG }
\end{aligned}
$$


where:

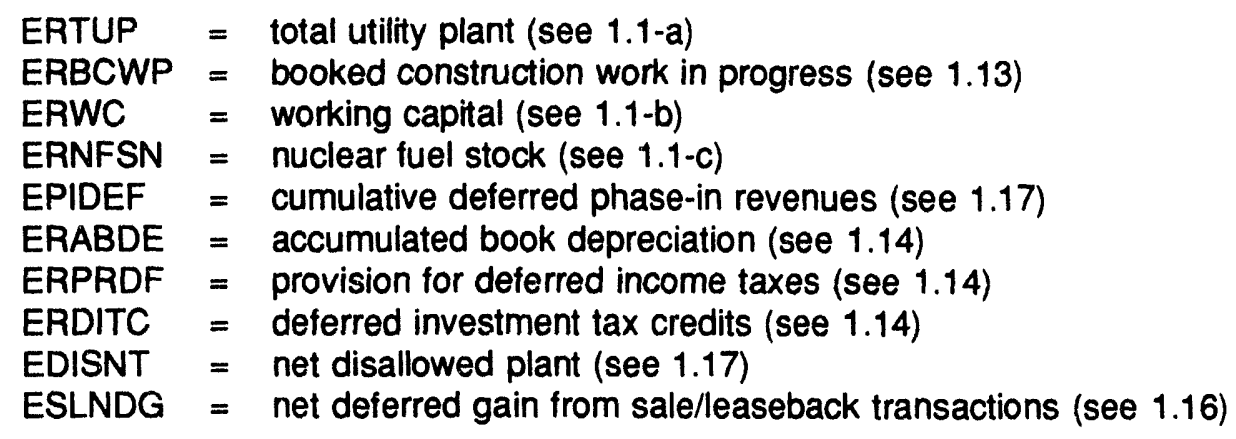

\subsection{Federal Income Taxes for Regulatory Purposes (FEDREG)}

FEDREG is equal to Federal taxable income (for regulatory purposes) multiplied by the Federal income tax rate, adjusted by several accounts reflecting timing differences between actual income taxes paid and regulatory income taxes:

FEDREG $=$ (ERRVRQ - ERTFLN - ERTOMN - GENREG - STAREG - ERTDRG - ERTIEX + ERCIDC - ESLLP) * ESFTXR - ERFITC - ERAITC - ERFFDC - ERAFDC EREDTF

where:

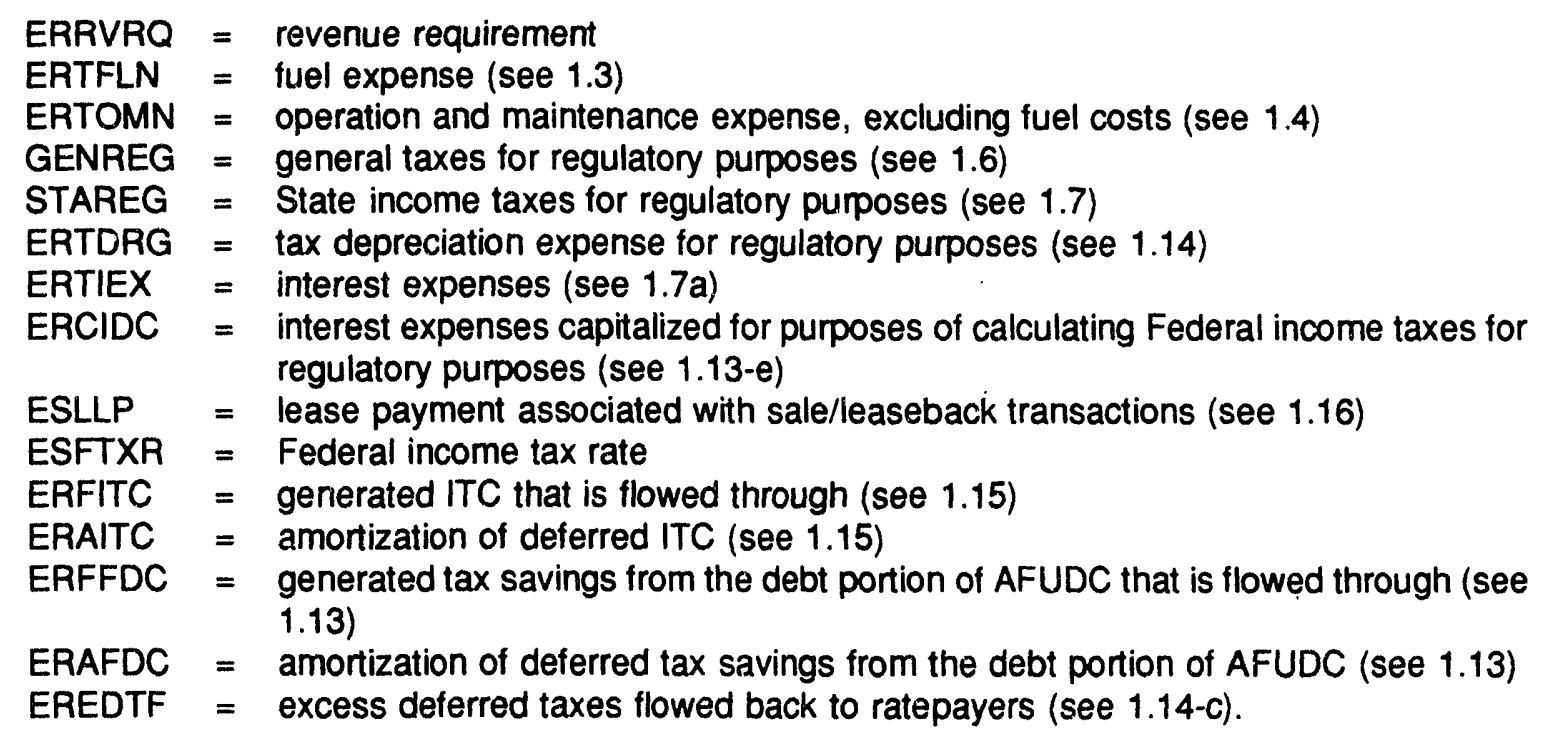

ERRVRQ on the right side of the equation is discussed in 1.12. ESFTXR is a user-supplied input. FEDREG includes the effects of the ITC or the tax savings due to the debt portion of AFUDC. These effects are captured with the variables ERFITC, ERAITC, ERFEDC, and ERAFDC. 


\subsection{AFUDC Offset (EROFFS)}

See Section 1.13

\subsection{Net Lease Payments Associated with Sale/Leaseback Transactions (ESLLPN)}

See Section 1.16.

\subsection{Net Deferred Phase-in Revenues (EPIND)}

See Section 1.17

\subsection{Resolution of ERRVRQ "Circular" Argument}

The following four equations have been presented:

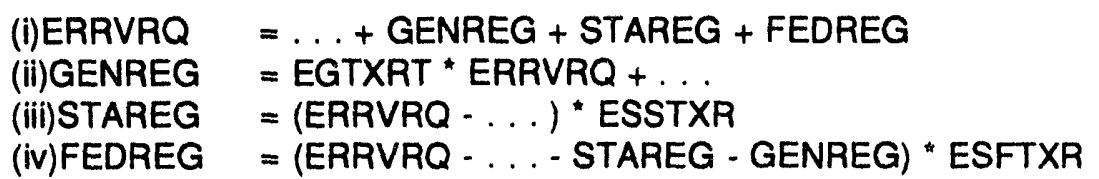

In the somewhat linear presentation of Sections 1.1 through 1.11 , the above equations seem to present a circular argument. (ERRVRQ is a function of GENREG, STAREG, and FEDREG, but also the later variables depend on ERRVRQ.) This specification, of course, is not really a problem. The above is just a system of four linear equations with four unknowns. Using the method known as algebraic substitution, one can solve for the value of ERRVRR, as follows:

First, the above equations (ii), (iii), and (iv) can be substituted into equation (i) to yield:

$$
\begin{aligned}
\text { ERRVRQ }= & \ldots \text { + ERRVRQ * EGTXRT + (ERRVRQ }-\ldots) * \text { ESSTXR } \\
& +(\text { ERRVRQ - .. - STAREG - GENREG }) * \text { ESFTXR }
\end{aligned}
$$

Next, substituting equations (ii) and (iii) into the above equation and gathering like terms yields:

$$
\begin{aligned}
\text { ERRVRQ }= & \ldots \text { + ERRVRQ * EGTXRT * }(1-\text { ESFTXR })+(\text { ERRVRQ }-\ldots){ }^{*} \text { ESSTXR * } \\
& (1-\text { ESFTXR })+(\text { ERRVRQ }-\ldots) * \text { ESFTXR }
\end{aligned}
$$

Next, moving all terms on the right hand side of the equation that contain the variable ERRVRQ to the left hand side yields:

$$
\begin{aligned}
& \text { ERRVRQ * } \\
& \begin{array}{c}
(1-\text { EFTXRT * }(1-\text { ESFTXR })-\text { ESSTXR * } \\
\begin{array}{c}
1 \\
+
\end{array} \\
+(-\ldots) * \text { ESSTXR } *(1-\text { ESFTXR }) \\
+(-\ldots) * \text { ESFTXR }
\end{array}
\end{aligned}
$$

Finally, dividing the equation on both sides by the constant on the left hand side yields:

$$
\begin{aligned}
& \text { ERRVRQ }=(\ldots \\
& +(-\ldots) * \text { ESSTXR* } \\
& +(-\ldots) * \text { ESFTXR })
\end{aligned}
$$




$$
\text { / (1 - EGTXRT * (1 - ESFTXR) - ESSTXR * (1 - ESFTXR) - ESFTXR) }
$$

This equation yields a unique value for ERRVRQ. This value can then be substituted back into equations (ii), (iii), and (iv) to yield values for the remaining variables.

\subsection{Construction Work in Progress (CWIP)}

For regulatory purposes, EFP is able to simulate three alternative treatments of construction work in progress: 1) CWIP in rate base; 2) CWIP not in rate base; or 3) the offset method. When CWIP is allowed in rate base for ratemaking purposes, the utility is allowed to earn a current cash return on all construction outlays. If CWIP is not allowed in rate base (i.e., AFUDC is capitalized) the utility is allowed to include an annual estimate of the net cost, for the period of construction, of funds used for construction purposes. These "allowances" are accumulated over the construction period of the project and are brought into the rate base as an addition to the value of the completed investment once the investment becomes operational. The third alternative of dealing with construction work in progress is the capitalized AFUDC offset method. For this procedure, CWIP is allowed in rate base and AFUDC is capitalized, but there is a corresponding offset to the return on rate base equal to the amount of the capitalized AFUDC. If the AFUDC rate is equal to the allowed rate of return on rate base and if the utility is allowed to compound the effects of AFUDC then this method is essentially equivalent to not allowing CWIP in rate base.

The regulatory treatment of CWIP is decided upon a case-by-case basis by most public utility commissions. In general, at the multi-utility aggregation level at which EFP is nun, all of the treatments are used to some degree. To account for this, EFP allows the analyst to input the percentage of CWIP that is to be allowed in rate base. The remainder of the CWIP is then assumed either not to be in rate base or to be handled under the offset method (depending on another user input).

The treatment of CWIP affects quite a few variables. These effects will now be discussed. All of the discussions will assume only one plant is being built. This is for ease in presentation only, and going to the " $n$ " plant case presents no conceptual problems. For the presented algorithms, the following values are input to EFP:

$\begin{array}{lll}\text { Varlable } & \text { Description } & \text { Source } \\ \text { EBPCAP } & \text { Capacity of build } & \text { Distribution Planning Model } \\ \text { EBPCST } & \begin{array}{l}\text { Real dollar cost per unit of capacity } \\ \text { (real dollars/capacity), not including } \\ \text { any financing costs incurred during } \\ \text { construction }\end{array} & \text { Distribution Planning Model } \\ & \begin{array}{l}\text { Year plant comes on line } \\ \text { EBSYR }\end{array} & \text { Distribution Planning Model } \\ \text { ESLCP } & \begin{array}{l}\text { Length (in yeais) of construction } \\ \text { period (including first year of opera- } \\ \text { tion) }\end{array} & \text { User } \\ \text { ESCPRF } & \begin{array}{l}\text { Direct (i.e., not including financing } \\ \text { charges) construction expenditures (in } \\ \text { real dollars) in year j as a fraction of } \\ \text { total direct construction costs (in real } \\ \text { dollars) }\end{array} & \\ & & \end{array}$




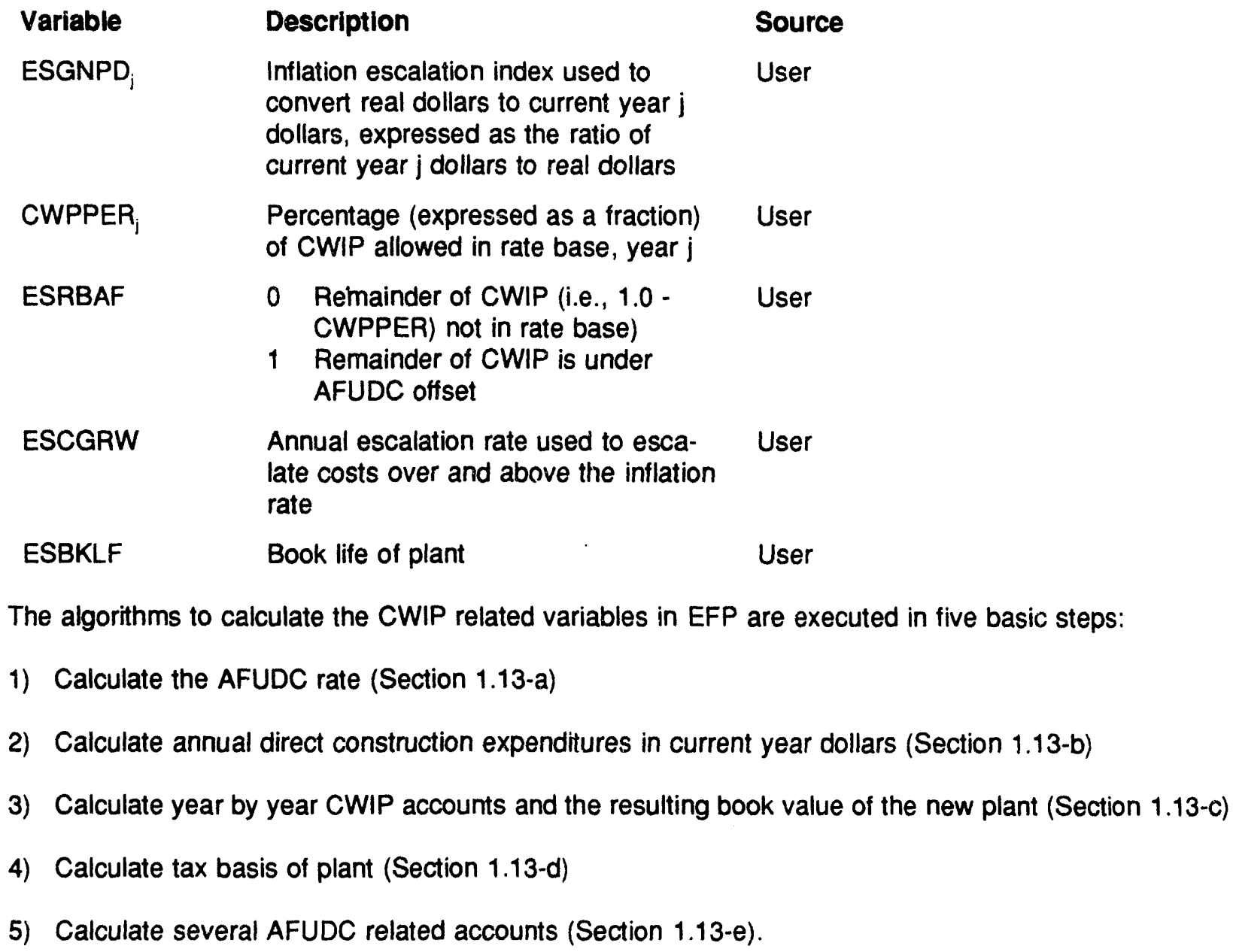

ESCGRW Annual escalation rate used to esca-

User late costs over and above the inflation rate

ESBKLF

Book life of plant

User

The algorithms to calculate the CWIP related variables in EFP are executed in five basic steps:

1) Calculate the AFUDC rate (Section 1.13-a)

2) Calculate annual direct construction expenditures in current year dollars (Section 1.13-b)

3) Calculate year by year CWIP accounts and the resulting book value of the new plant (Section 1.13-c)

4) Calculate tax basis of plant (Section 1.13-d)

5) Calculate several AFUDC related accounts (Section 1.13-e).

Each step is now discussed in detail.

\subsection{3-a Step 1}

Step 1 is to calculate the AFUDC rate. EFP simulates a pre-tax AFUDC rate. EFP calculates the pre-tax AFUDC rate as:

ESAFDC $=$ TEMPD + TEMPE

where:

TEMPD $=$ ESPRLT ${ }^{*}$ ESEMDL + ESPRST * ESRTST
TEMPE $=$ ESPRCE * ESRTCE + ESPRPS * ESEMPL

All of the right-hand variables above are discussed in Section 1.2. An additional value used below is the fraction of AFUDC representing debt costs.

ESWACD $=$ TEMPD/ESAFDC 
where:

ESWACD $=$ fraction of AFUDC representing debt costs.

\subsection{3-b Step 2}

Step 2 is to calculate direct construction expenditures by year, in nominal dollars. This is done for each year $j$, where $j$ ranges from the first year of construction (i.e., EBSYR - ESLCP +1 ) to the first year of operation (i.e., EBSYR).

$$
\begin{aligned}
& \text { EBYCWP }_{i}=\text { EBPCAP * EBPCST * ESCPRF }_{j} \text { " ESGNPD }{ }_{i}^{*} \text { CAPESC }_{i} \\
& \text { for } j=(E B S Y R-E S L C P+1) \text { to EBSYR }
\end{aligned}
$$

where:

$$
\begin{aligned}
& \text { EBYCWP }_{j}=\text { nominal dollar direct construction expenditures, year } j \\
& \text { EBPCAP }=\text { capacity of build } \\
& \text { EBPCST }=\text { real dollar cost per unit of capacity } \\
& \text { ESCPRF }_{j}=\text { real dollar direct construction expenditures, in year } j, \text { as a fraction of total direct } \\
& \text { ESGNPD }_{j}=\text { inflation index to convert real dollars to current year } j \text { dollars } \\
& \text { CAPESC }_{j}=\text { escalation index to escalate construction costs over and above inflation } \\
& \text { EBSRY }=\text { year plant comes on line } \\
& \text { ESLCP }
\end{aligned}
$$

EBPCAP, EBPCST, ESCPRF, ESGNPD, EBSYR, and ESLCP are inputs to EFP. CAPESC is calculated from the input values of ESCGRW (see description above of user inputs).

\subsection{3-c Step 3}

This step includes calculation of the major CWIP-related accounts for each year $j$ during the construction period. This includes year by year: CWIP allowed in rate base, booked CWIP, booked AFUDC, and the AFUDC offset. Also calculated is the book value of the new plant.

CWIP allowed in rate base is calculated as:

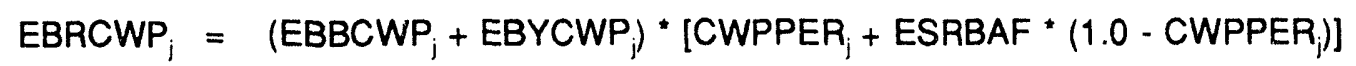

where:

$$
\begin{array}{ll}
\text { EBRCWP }_{j} & =\text { CWIP allowed in rate base, year } j \\
\text { EBBCWP }_{j-1}= & \text { booked CWIP, year } j-1 \\
\text { CWPPER }_{j} & =\text { percentage of CWIP allowed in rate base, year } j \\
\text { EBYCWP }_{j}= & \text { nominal dollar direct construction expenditures, year } j \\
\text { ESRBAF }=0 \text { if no AFUDC offset, and } 1 \text { if AFUDC offset. }
\end{array}
$$

Booked AFUDC in year $j$ is calculated as: 
AFUDC $_{i}=\left(\right.$ EBBCWP $_{j-1}+.5 *$ EBYCWP $\left._{j}\right) *\left(1-\right.$ CWPPER $\left._{j}\right) *$ ESAFDC $_{j}$

where:

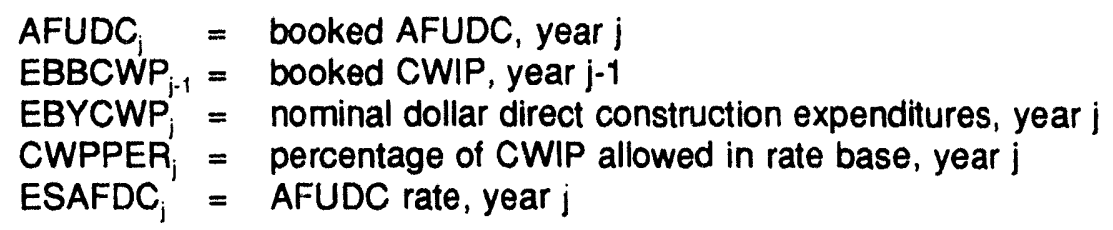

Note that in the calculation of AFUDC the average level of CWIP over the calendar year is used. This is why EBYCWP is multiplied by one-half (the construction takes place evenly over the year so the average balance should include only half of this amount). The calculation of CWIP in rate base, however, uses an end-of-year CWIP balance. Adjustments to this value to make it an average level over the year are made only if the user requests an average-year rate base.

ESAFDC and EBYCWP were calculated above in Steps 1 and 2, respectively. The calculation of EBBCWP is shown below.

Booked CWIP in year $j$ is calculated as:

$$
\begin{aligned}
\text { EBBCWP }_{i}= & 0 \text { for } \mathrm{j}=\quad \text { EBSYR }- \text { ESLCP (i.e., year before construction begins } \\
= & \text { EBBCWP }_{\mathrm{j}-1}+E \text { EBYCWP }_{\mathrm{i}}+\text { AFUDC }_{\mathrm{i}} \\
& \text { for } \mathrm{j}=\quad \text { (EBSYR }-E S L C P+1) \text { to EBSYR (i.e., construction period) }
\end{aligned}
$$

where:

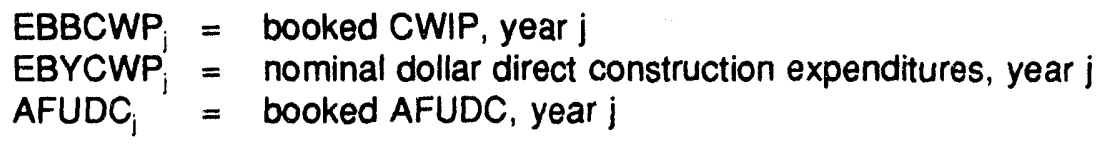

The AFUDC offset is calculated as:

$$
\text { EROFFS }_{i}=\text { AFUDC }_{i}{ }^{*} \text { ESRBAF }
$$

where:

$$
\text { EROFFS }_{j}=\text { AFUDC offset, year } j \text {. }
$$

The book value of the new plant when it comes on line is:

$$
\text { EBBKVL }=\text { EBBCWP }_{\mathrm{j}}
$$


where:

$$
\begin{array}{ll}
j & =\text { EBSYR (the first year of operation) } \\
\text { EBBKVL } & =\text { book value of new plant }
\end{array}
$$

This equation assumes that the new plant comes on line January 1 of year EBBSYR. EFP can also simulate plants coming on line after January 1 , using similar equations.

\subsection{3-d Step 4}

The fourth step is to calculate the tax basis for the investment. Previous to the Tax Reform Act (TRA) of 1986, the tax basis was the sum over all years of the nominal dollar direct construction expenditures (EBYCWP) calculated in Step 2 (adjusted for investment tax credits as described in 1.14-b.). However, any asset coming on line after 1986, that is not grand-fathered under the provision must capitalize interest during construction.

$$
\begin{aligned}
& \text { EBASVL }_{i}=0 \quad \text { for } \mathrm{j}=\text { EBSYR }- \text { ESLCP (i.e., year before construction } \\
& \text { begins) } \\
& =E B A S V L_{j-1}+E B Y C W P_{j}+A V D I N T_{i} \\
& \text { for } j=(E B S Y R-E S L C P+1) \text { to EBSYR (i.e., construction } \\
& \text { period) } \\
& =\text { EBASVL EBSYR } \quad \text { for } j=\text { EBSYR to }(E B S R Y+E S B K L F) \\
& \text { (i.e., during service life) }
\end{aligned}
$$

where:

$\begin{array}{lll}\text { EBASVL } & =\text { tax basis, year } j \\ \text { EBYCWP }_{i} & =\text { nominal dollar direct construction expenditures, year } j \\ \text { AVDINT }_{j} & = & \text { interest capitalized for tax basis (avoided interest), year } j\end{array}$

No interest is capitalized for the tax basis unless the plant is covered under the TRA. The applicability of the TRA to a given plant is determined by a user-defined test based on the year the plant came on line and first year of construction. When the new tax law does apply, the capitalized interest is calculated as:

$$
\text { AVDINT }_{j} \quad=\quad\left(\text { EBASVL }_{j-1}+.5^{*} \text { EBYCWP }_{j}\right)^{*} \text { ESRTNB }_{j}
$$

where:

$\begin{array}{lll}\text { AVDINT }_{i} & = & \text { interest capitalized for tax basis (avoided interest), year } j \\ \text { EBASVL }_{j-1} & =\text { tax basis, year } j-1 \\ \text { EBYCWP }_{j} & =\text { nominal dollar direct construction expenditure, year } j \\ \text { ESRTNB }_{j} & =\text { cost of new debt, year } j .\end{array}$

\subsection{3-e Step 5}

The fitth step is to calculate several accounts related to AFUDC. 
It is important to separate AFUDC into that financed by debt and that financed by equity:

$\begin{array}{ll}\text { ERFDCD }_{i} & =\text { ESWACD }_{i} \text { AFUDC }_{i} \\ \text { ERFDCE }_{i} & =\left(1-\text { ESWACD }_{i}\right) * \text { AFUDC }_{i}\end{array}$

where:

$\begin{array}{lll}\text { ERFDCD }_{i} & = & \text { debt financed portion of AFUDC, year } j \\ \text { ERFDCE }_{i} & = & \text { equity financed portion of AFUDC, year } j \\ \text { ESWACD }_{i} & = & \text { fraction of AFUDC representing debt costs, year } j \text { (see step 1) }\end{array}$

While a plant is under construction, various interest expenses associated with construction of the plant accrue. For those plants not covered under the TRA, this interest expense provides a tax savings to the utility because interest is a deductible expense. The regulatory process attempts to capture this savings for ratemaking purposes and either flow it through immediately to ratepayers or defer it to a later period when the asset is in service. This is done by using the concept of the tax savings due to the debt portion of AFUDC.

$$
\begin{aligned}
& \text { ERFFDC }_{\mathrm{i}}=\text { ERFDCD }_{\mathrm{j}} \text { *ESFTXR * ESFPDB } \\
& \text { ERXFDC }_{i}=\text { ERFDCD }_{i}{ }^{*} \text { ESFTXR * }(1-\text { ESFPDB }) \\
& \text { DAFDC }_{i}=\sum_{i=k} \text { ERXFDC }_{i} \\
& \text { for } j=K \text { to EBSYR where } K=\text { EBSYR }- \text { ESLCP }+1
\end{aligned}
$$

\begin{tabular}{|c|c|c|}
\hline ERFFDC $_{i}$ & $=$ & $\begin{array}{l}\text { generated tax savings from the debt portion of AFUDC that is flowed } \\
\text { through, year i }\end{array}$ \\
\hline ERFXFDC $_{i}$ & $=$ & $\begin{array}{l}\text { generated tax savings from the debt portion of AFUDC that is deferred } \\
\text { (normalized), year j }\end{array}$ \\
\hline $\begin{array}{l}\text { DAFDC }_{i} \\
\text { ERFDCD } \\
\text { ESFTXR } \\
\text { ESFPDB }\end{array}$ & $\begin{array}{l}= \\
= \\
=\end{array}$ & $\begin{array}{l}\text { deferred tax savings from the debt portion of AFUDC, year j } \\
\text { debt-financed portion of AFUDC, year j, (see above) } \\
\text { Federal tax rate (user input) } \\
\text { flow through percentage (expressed as a fraction) for AFUDC tax savings. }\end{array}$ \\
\hline
\end{tabular}

where:

ESFPDB reflects the regulatory policy towards the tax savings and is a user input. The tax savings is generated while the plant is under construction. When the plant begins service, the deferred taxes, if any, are amortized over the service life of the plant.

$$
\begin{aligned}
& \text { EBAFDC }=\text { DAFDC }_{\text {EBSYR }} / \text { ESBKLF }
\end{aligned}
$$

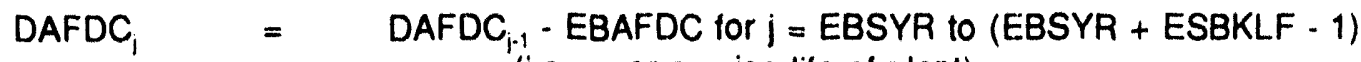

$$
\begin{aligned}
& \text { (i.e., over service life of plant) }
\end{aligned}
$$


where:

$\begin{array}{lll}\text { EBAFDC } & = & \text { annual amortization of deferred savings from the debt portion of AFUDC } \\ \text { DAFDC } & = & \text { deferred tax savings from the debt portion of AFUDC, year } j \\ \text { ESBKLF } & = & \text { book life of plant }\end{array}$

Again, the calculations above pertaining to the tax savings from the debt portion of AFUDC relate only to plants not covered under the TRA of 1986. For plants covered under the TRA of 1986, there is no tax savings because interest must be capitalized for tax purposes. The interest capitalized for the purposes of calculating Federal income taxes for regulatory purposes is therefore:

$$
\text { ERCIDC }_{j}=\text { ERXFDC }_{j}+\text { AVDINT }_{j}
$$

where:

$\begin{array}{ll}\text { ERCIDC }_{i} & =\quad \begin{array}{l}\text { interest capitalized for the purposes of calculating Federal income taxes } \\ \text { for regulatory purposes, year } j\end{array} \\ \text { ERXFDC }_{i} & =\quad \begin{array}{l}\text { generated tax savings from the debt portion of AFUDC that is deferred, } \\ \text { year } j\end{array} \\ \text { AVDINT }_{j} & =\quad \text { interest capitalized for tax basis, year } \mathrm{j} \text { (see Step } 4 \text { above). }\end{array}$

\subsection{Depreciation}

Depreciation expenses are calculated separately for financial (or book) and for tax purposes). Financial and tax depreciation differ for several reasons. First, book depreciation is calculated using the straight-line method while tax depreciation uses an accelerated method. The accelerated method yields higher depreciation in the early years of an asset's life followed by lower depreciation in later years than does the straight-line method (assuming all else equal). Second, capitalized AFUDC is depreciated for book purposes but not for tax purposes. Similarly, interest capitalized during construction for tax purposes is not depreciated for book purposes, but is for tax purposes. Finally, the depreciation base for tax purposes must be lowered by one-half of the total investment tax credit earned during construction of the plant. The depreciation base for book purposes is not adjusted in this way.

The following discussion applies to a new plant with the following input characteristics:

$\begin{array}{lll}\text { EBSYR } & = & \text { year plant comes on line } \\ \text { ESBKLF } & = & \text { book life of plant } \\ \text { ESDEPR } & = & \text { depreciation rate for financial purposes (usually } 1 / \text { ESBKLF) }\end{array}$

The methodology presented here is easily expanded to the " $n$ " plant case and to existing plants.

\subsection{4-a Depreciation for Financial Purposes (ERBDE)}

Book depreciation is calculated using the straight-line method (net book value divided by remaining life):

$$
\text { ERBDE }_{\mathrm{i}} \quad=\quad\left(\mathrm{EBBKVL} \cdot \mathrm{EBABDE}_{\mathrm{j}-1}\right) /(\mathrm{ESBKLF}-(\mathrm{J}-\mathrm{EBSYR}))
$$


and

$$
\begin{aligned}
& \text { EBABDE }_{i}= \sum_{i=E^{\prime}} \text { ERBSPE }_{i} \\
& \text { for } j=\text { EBSYR to EBSYR }+ \text { ESBKLF }-1 \\
& \text { (i.e., over service life of asset) }
\end{aligned}
$$

where:

$\begin{array}{lll}\text { ERBDE }_{\mathrm{i}} & = & \text { book depreciation, year } \mathrm{j} \\ \text { EBABDE }_{\mathrm{i}} & = & \text { accumulated book depreciation, year } \mathrm{j} \\ \text { EBBKVL } & = & \text { book value of plant (includes any AFUDC) }\end{array}$

The derivation of EBBKVL is discussed in section 1.11.c. When the plant retires (year EBSYR + ESBKLF), its book value is added to account ERBTIR and subtracted from EBABDE. This has the effect of removing the plant from the books. (See Section 1.1-a.)

\subsection{4-b Depreciation for Tax Purposes}

For tax purposes, depreciation is accelerated (i.e., allowed to be greater in early life of plant and less in later life) by two forces. First, utilities may depreciate the plant over a shorter period of time than the service life used for financial purposes. Second, an accelerated depreciation rate is used instead of a straight-line constant rate. The effect of this is to lower tax liability in the earlier years of the plant life and raise them in the later years, compared to the straight-line method.

There are three different options in EFP when determining tax depreciation rates: i) use those prescribed in the Tax Reform Act (TRA) of 1986; ii) use those prescribed in the 1981 Economic Recovery Tax Act (ERTA); or iii) use the sum-of-years digit method. The method used for a particular asset is based on a user-specified test, which is a function of the year the construction of asset begins and the year the asset comes on line. The sum-of-years digit method is used for any asset that comes on line before 1981. Because the first two methods are the most applicable approaches, they are discussed below. ${ }^{23}$

Under ERTA and TRA, tax depreciation schedules (now more properly called tax recovery schedules) are specified. The tax base, as modified under the Tax Equity and Fiscal Responsibility Act of 1982 (TEFRA), is reduced by one half of the investment tax credit (discussed in Section 1.15) earned during the construction of the asset. For a given asset, the relevant recovery schedule is determined based on when the asset comes on line and on what service life class the asset belongs. Most assets in EFP are depreciated over 15 years (some 10) under ERTA, and 20 years (some 15) under TRA. Then, for the remaining years of the book life, tax depreciation is zero.

$$
\begin{array}{ll}
\text { ERTDE }_{\mathrm{i}}= & \text { EXTXRS }_{\mathrm{j}}{ }^{*}\left(\mathrm{EBASV}-.5^{*}\right. \text { EBDITC) } \\
& \text { for } \mathrm{j}=\text { EBSYR to EBSYR + ESBKLF }-1 \\
& \text { (i.e., during the service life of the plant) }
\end{array}
$$

23 The approach for the sum-of-years digit method is identical to that described except that the tax base is not reduced by one-half the investment tax credit. 
where:

$\begin{array}{lll}\text { ERTDE }_{\mathrm{i}} & = & \text { depreciation expense for tax purposes, year } \mathrm{j} \\ \text { EBASVL } & = & \text { tax basis of asset } \\ \text { EXTXRS } & = & \text { depreciation rate prescribed by ERTA or TRA, year } \mathrm{j} \\ \text { EBDITC } & = & \text { investment tax credits generated. }\end{array}$

EBASVL is discussed in Section 1.13-c. EBDITC is described in Section 1.15.

Absent accelerated depreciation, tax depreciation would be:

ERTDWO $_{i}=$ ESDEPR * (EBASVL $\left.-0.5^{\star} E B D I T C\right)$
for $j=$ EBSYR to EBSYR + ESBKLF -1
(i.e., during the service life of the plant)

where:

$\begin{array}{ll}\text { ERTDWO }_{i} & =\text { depreciation for tax purposes, without acceleration, year } \mathrm{j} \\ \text { ESDEPR } & =\text { straight-line depreciation rate. }\end{array}$

The difference between ERTDWO and ERTDE, leads to tax savings in the early years of service followed by increased taxes in the later years. The regulatory authority determines the treatment of this difference for ratemaking purposes.

$$
\begin{aligned}
& \text { ERTDRG }_{\mathrm{i}}=\text { ERTDWO }_{\mathrm{i}}{ }^{*}(1-\mathrm{ESFLPR})+\text { ERTDE }_{\mathrm{j}}{ }^{*}(\mathrm{ESFLPR}) \\
& \text { for } j=E B S Y R \text { to EBSYR + ESBKLF - } 1 \\
& \text { (i.e., during the service life of the plant) }
\end{aligned}
$$

where:

$$
\begin{array}{lll}
\text { ERTDRG }_{\mathrm{i}} & = & \begin{array}{l}
\text { tax depreciation expense for regulatory purposes, year } j \\
\text { ESFLPR }
\end{array} \quad=\begin{array}{l}
\text { percentage of tax savings due to acceleration depreciation that is flowed } \\
\text { through }
\end{array}
\end{array}
$$

When the tax effects of accelerated depreciation are flowed through for regulatory purposes (ESFLPR = 1.0), ERTDRG is equal to ERTDE. In this case, revenue requirements directly show the effects of the acceleration. However, when the tax effects are normalized (ESFLPR $=0.0$ ), then ERTDRG is equal to ERTDWO and thus the revenue requirements show no effects of the acceleration. Thus, in a flow-through scenario, revenue requirements are lower in the early years of the plant's service and higher in the later years, compared to revenue requirements in a normalized scenario (all else equal). This effect comes about because ERTDRG affects Federal income taxes for regulatory purposes, which in turn affects revenue requirements.

Other useful quantities relating to this tax effect are:

$$
\begin{array}{lll}
\text { ERATSF }_{j} & = & \text { ESFTXR }^{*}\left(\text { ERTDE }_{i}-\text { ERTDWO }_{i}\right) * E^{*} \text { ESLPR } \\
\text { ERATSD }_{j} & = & \text { ESFTXR }^{*}\left(\text { ERTDE }_{j}-\text { ERTDWO }_{i}\right) *(1-E S F L P R)
\end{array}
$$




$$
D_{i=} \quad=\sum_{i=\text { EBSYR }} \text { ERATSD }_{i} \text { for } j=\text { EBSYR to EBSYR }+ \text { ESBKLF }-1
$$

where:

$\begin{array}{ll}\text { ERATSF }_{i} & =\quad \begin{array}{l}\text { tax savings resulting from accelerated depreciation that are flowed } \\ \text { through, year } j \\ \text { tax savings resulting from accelerated depreciation that are deferred, year }\end{array} \\ \text { ERATSD }_{i} & =\quad \begin{array}{l}\mathrm{j} \\ \text { provision for deferred taxes due to accelerated tax depreciation, year } j\end{array} \\ \text { DAD }_{\text {ESTXR }} & =\text { Federal income tax rate. }\end{array}$

\subsection{4-c Excess Deferred Income Taxes Flowed Back to Ratepayers (EREDTF)}

The 1986 Tax Reform Act (TRA) lowered the marginal Federal income tax rate from 46 percent to 40 percent in 1987 and to 34 percent thereafter. One effect of the decrease in the marginal tax rate is to lower future reductions in deferred income taxes that will occur as assets complete their service lives.

As described in Section 1.14-b, accelerated depreciation allowed for tax purposes leads to deferred income taxes for regulated utilities. Over the life of an individual asset the level of deferred income taxes will increase in its early years and finally decrease to zero at the end of its service life. A complication arises, however, when the marginal tax rate decreases during the service life of an asset. The deferred taxes have been booked at the higher marginal tax rate, but will now be paid at the lower tax rate. The difference between deferred income taxes now booked (under the 46-percent marginal tax rate) and what will uttimately be paid under the 34-percent marginal rate is referred as excess deferred income taxes.

These excess deferred taxes should be flowed through to the ratepayers. EFP can flow back these taxes over the remaining lives of the assets or over any user-defined schedule of years.

The first step is to calculate the amount of deferred taxes that have accrued:

$$
\text { EXCESS } \left.\quad=\quad \sum_{j=\text { EBSYR }^{\text {YERTT }}}^{\text {YREDT }} \text { ERTDWO }_{j}\right) *\left(\text { ESFTXR }_{j}-\text { ESFTXR }_{\text {IYAEDT }}\right)
$$

where:

$\begin{array}{lll}\text { EXCESS } & = & \text { total excess deferred income taxes } \\ \text { ERTDE } & = & \text { depreciation expense for tax purposes, year } j \text { (see 1.14-b) } \\ \text { ERTDWO } & = & \text { depreciation for tax purposes, without acceleration, year } j \text { (see 1.14-b) } \\ \text { ESFTXR } & =\text { Federal income tax rate, year } j \text { (user input) } \\ \text { EBSYR } & = & \text { first year of service } \\ \text { IYREDT } & =\text { year in which excess taxes are to be calculated (user input) }\end{array}$

Now the amount of excess deferred income taxes flowed back to ratepayers in each year can be calculated:

$$
\text { EREDTF }_{j}=0.0 \quad \text { if } j<\text { IYREDT }
$$




$$
=\text { EXCESS/REMLIF if } j \geq \text { IYREDT }
$$

where:

$\begin{array}{lll}\text { EREDTF } & = & \text { excess deferred taxes flowed back to ratepayers each year } \\ \text { EXCESS } & = & \text { total excess deferred income taxes } \\ \text { REMLIF } & = & \text { remaining years of life for asset (ESBKLF - (IYREDT-EBSYR)) }\end{array}$

The above equation flows back the excess deferred income taxes over the remaining life of the investment. Within EFP, it can also be flowed back over any user-defined schedule of years.

\subsection{4-d Provision for Deferred Income Taxes (ERPRDF)}

The provision for deferred income taxes is the sum of the values of all deferred income taxes or deferred tax savings (excluding investınent tax credits). For purposes of EFP, ihis includes the deferred taxes from accelersted depreciation and the deferred tax savings from the debt portion of AFUDC on assels not affected by the TRA of 1986.

$$
\text { ERPRDF } \quad=\quad \text { DAD + DAFDC - EREDTF }
$$

where:

$\begin{array}{lll}\text { ERPRDF } & = & \text { provision for deferred income taxes } \\ \text { DAD } & = & \text { deferred income taxes due to accelerated depreciation (see Section 1.14- } \\ \text { b) }\end{array}$

\subsection{Investment Tax Credit}

The investment tax credit was established by Congress to encourage certain kinds of investments. The effect of the investment tax credit is to reduce the Federal tax liability by the amount of the credit. The credit is generated during each year of the construction period for the plant. Previous to the Tax Reform Act of 1986 (TRA), the value of the credit each year was a percentage of construction expenses (excluding AFUDC) for that year. The investment tax credit was repealed under TRA. However, many assets currently under construction when the TRA was passed were grand-fathered under the provision and will continue to receive the credit. For these assets, the effective investment tox credit rate will decrease over time. Within EFP, assets that receive the credit are determined by a user-specified test that is a function of the year in which the construction of the asset began and the year in which the asset enters service (i.e., any asset for which constiuction began before a user-specified year and which enters service before a user-specified year, will continue to receive the credit). This test allows the capability to examine alternative assumptions regarding grand-fathering.

The regulatory treatment of this tax savings is decided by the new regulatory commission. The credit can be flowed through immediately to lower the revenue requirement in the year it was generated or deferred and then amortized over the life of the plant. EFP handles any combination of these two treatments.

$\begin{array}{lll}\text { ERFITC }_{i} & =\text { EBYCWP }_{j} * \text { ESRITC }_{i}{ }^{*} \text { ESFLPR } \\ \text { XITCD }_{j} & =\text { EBYCWP }_{j} * \text { ESRITC }_{j}^{*}\left(1-\text { ESFLPR }^{\prime}\right.\end{array}$




$$
\text { EBDITC }_{i}=\sum_{i=K} X_{T C D} \quad \begin{aligned}
& \text { for } j=K \text { to EBSYR } \\
& \text { where } K=\text { EBSYR }- \text { ESLCP }+1
\end{aligned}
$$

where:

$\begin{array}{lll}\text { ERFITC }_{i} & =\text { generated ITC that is flowed through, year } j \\ \text { XITCD }_{j} & =\text { generated ITC that is deferred, year } j \\ \text { EBDITC }_{j} & =\text { deferred ITC, year } j \\ \text { EBYCWP } & =\text { construction expenses, net of AFUDC, year } j \text { (see 2.1.13-b) } \\ \text { ESRITC } & =\text { investment tax credit rate, year } j \\ \text { ESFLPR } & =\text { percentage of tax savings flowed through } \\ \text { ESLCP } & =\text { length (in years) of construction period (including first year of operation) }\end{array}$

When the plant begins service, any deferred ITC is amortized over the life of the plant.

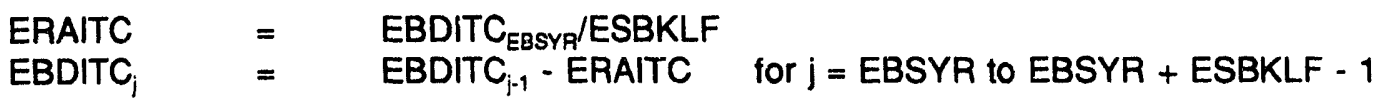

where:

$\begin{array}{lll}\text { ERAITC } & = & \text { amortization of deferred investment tax credit } \\ \text { EBDITC } & = & \text { deferred ITC, year } j,(\text { see 1.13-c) } \\ \text { ESBKLF } & = & \text { service life of plant (user input) }\end{array}$

Note that the investment tax credit is generated only on the direct construction expense, not on capitalized AFUDC.

\subsection{Sale/Leaseback Transactions}

The sale and leaseback of an electric power plant is essentially a financial transaction that affects the timing of cost recovery, and frequently the capital cost, associated with the plant. It generally does not change the utility's responsibilities for operating and maintaining the plant or for selling the electricity it generates. Attractive for a variety of reasons, the sale/leaseback may be a creative way for a utility to circumvent constraints imposed by regulatory authorities, competition, bond indemnifications, or its tax position, benefiting both investors and ratepayers.

In the simplest form of a sale or leaseback, the utility sells a power plant to an institutional investor, then leases the plant back from the investor for equal semiannual rents over a term that is typically between 25 and 30 years. Regulators treat the rental payment as operating expenses, and the utility's revenue requirement no longer includes the return on capital or depreciation expense associated with the plant. The result is a flat revenue requirement over time, lower than conventional cost recovery in the short term, and higher toward the end of the lease.

For the algorithm presented below, the following values are input in EFP for each sale/leaseback transaction to be modeled:

Variable Description

IBYRSL Year transaction is completed 


$\begin{array}{ll}\text { SLPROC } & \text { Gross proceeds from transaction } \\ \text { BKGAIN } & \text { Gross gain on book value } \\ \text { SLTAXS } & \text { Utility income taxes on transaction } \\ \text { SLLP } & \text { Annual lease payment } \\ \text { SLTERM } & \text { Lease term }\end{array}$

The methodology presented here applies to one transaction and is easily expanded to the " $n$ " transaction case.

The first step is to calculate the book value of the plant sold, the net gain from the transaction, and the tax basis of the plant sold:

$\begin{array}{lll}\text { SLBKVL } & = & \text { SLPROC - BKGAIN } \\ \text { SLGAIN } & = & \text { BKGAIN }- \text { SLTAXS } \\ \text { SLASVL } & = & \text { SLPROC - SLTAXS/ESFTXR }\end{array}$

where:

$\begin{array}{lll}\text { SLBKVL } & = & \text { book value of plant sold } \\ \text { SLPROC } & = & \text { gross proceeds from transaction (input) } \\ \text { BKGAIN } & = & \text { gross gain on book value (input) } \\ \text { SLGAIN } & = & \text { net gain on book value } \\ \text { SLTAXS } & = & \text { utility income taxes on transaction (input) } \\ \text { SLASVL } & = & \text { tax basis of plant sold } \\ \text { ESFTXR } & = & \text { federal income tax rate (input). }\end{array}$

The book value of the plant is removed from utility plant in service and the tax basis is removed from the utility tax accounts. This is done within the EFP by creating an asset with a negative book value and tax basis equal in absolute value to that calculated above. This has the effect of removing the plant from utility books.

The remaining quantities are now calculated:

$\begin{array}{lll}\text { ESLPRC } & = & \text { SLPROC }- \text { SLTAXS } \\ \text { ESLLP } & = & \text { SLLP } \\ \text { ESLAGN } & =\text { SLGAIN } / S L T E R M \\ \text { ESLNDG }_{j} & =\text { SLGAIN }-j{ }^{*} \text { ESLAGN for } j=1, \text { SLTERM } \\ \text { ESLLPN } & \text { ESLLP - ESLAGN }\end{array}$

where:

$\begin{array}{lll}\text { ESLPRC } & = & \text { net of tax sales proceeds } \\ \text { ESLLP } & = & \text { annual lease payment } \\ \text { ESLAGN } & = & \text { amortization of gain } \\ \text { ESLNDG } & = & \text { net deferred gain from transaction } \\ \text { ESLLPN } & = & \text { net least payment } \\ \text { SLPROC } & = & \text { gross proceeds from transaction (input) } \\ \text { SLTAXS } & = & \text { utility income taxes on transaction (input) } \\ \text { SLLP } & = & \text { annual lease payment (input) } \\ \text { SLGAIN } & = & \text { net gain on book value }\end{array}$


SLTERM $=$ lease term.

\subsection{Rate Phase-in Plans}

Almost all electric utilities in the United States have their electricity rates set by regulatory commissions at the local, State, or Federal level (or any combination of these three). The most common method used by regulators to determine the appropriate rates is often referred to as original-cost, rate-of-return regulation. Under this methodology, the utility is able to charge rates that allow it to recover its operating and capital costs. Under this scheme, the rate impacts of the capital costs of a new asset coming on line are greatest in its first year of service and decline thereafter over the life of the asset. Historically, the large increase in capital costs associated with a new plant were substantially, if not totally, offset by the lower operating costs obtained by utilizing the new unit.

In recent years, however, many situations have arisen where, under traditional regulation, substantial rate increases would occur as new plants com eon line. This has been caused by two major forces. First, the costs of new power plants have risen substantially. This widely discussed phenomenon has caused the capital costs of the plant to be substantially higher. Second, at the same time, the savings derived from lower operating costs of the new plants have not been very great. This is due to lower energy commodity prices as well as the power generation technologies leveling out in terms of efficiency. Additionally, many areas of the country were over-built with capacity, again lowering the savings derived from the new plants. In many cases, a single utility has brought on line a new plant whose total costs make up a large fraction of its total assets, thus amplifying the two forces just described.

Given this pressure for dramatic increases in rates, alternative regulatory approaches were necessary. Even if a regulatory commission were to allow the large rate increases, the potential reaction of customers, particularly large customers, forbids such rate increases. The prospect of these customers leaving the service territory or bypassing the local utility through cogeneration or transmission wheeling is very real. Any exit of these customers requires the rates of remaining customers to increase even more, and everincreasing rates and ever-declining sales become a possibility. In the interests of both the utilities and the ratepayers, a common approach to deal with this problem has emerged and is referred to as rate phase-in plans.

The idea of a rate phase-in plan is straightforward. For a number of years, raies are to be set at a level lower than would have been the case under traditional ratemaking. This is followed by a number of years in which rates are higher than they would have been in order to allow the company to make up for the early years. In practice, each rate phase-in plan is at least somewhat unique in response to the particulars of the situation.

For the algorithm presented below, the following values are input for each rate phase-in plan to be modeled:

$\begin{array}{ll}\text { Variable } & \text { Description } \\ \text { IBYRPI } & \text { Year rate phase-in plan begins } \\ \text { PIBKVL } & \text { Book value of phase-in plant } \\ \text { DISPER } & \text { Fraction of phase-in plant disallowed } \\ \text { LIP } & \text { Length of phase-in plan } \\ \text { PIDFS } & \text { Cumulative fraction of total cost to be phase-in in year } j \\ \text { PIRCS } & \text { Fraction of remaining deferred revenues to be recovered in year } j \\ \text { IRDPI } & \text { Logical variable indicating whether capitalized return is earned on deferred }\end{array}$


$\begin{array}{ll}\text { PIBKLF } & \text { Book life of phase-in plant } \\ \text { PITXBS } & \text { Tax basis as a fraction of book basis for phase-in plant }\end{array}$

The methodology presented here applies to one rate phase-in plan and is easily expanded to the " $n$ " plan case.

The first step is to calculate the total revenue requirement associated with the phase-in plant under traditional regulation for each year of the phase-in plan:

$$
\begin{aligned}
& \left.\mathrm{RR}_{\mathrm{i}} \quad=\quad \text { PIBKVL * }(1.0-\text { DISPER }) *(1.0-\mathrm{j} / \mathrm{PIBKLF}) * \text { ESPR/(1.0-ESFTXR }\right)+ \\
& \text { PIBKVL / PIBKLF * }(1.0+(1.0 \text { - PITXBS) * ESFTXR/(1.0 - ESFTXR))) } \\
& \text { for } j=1, L P I
\end{aligned}
$$

where:

$\begin{array}{lll}\mathrm{RR}_{\mathrm{i}} & = & \text { traditional revenue requirement of phase-in plant, year } \mathrm{j} \\ \mathrm{PIBKVL} & = & \text { book value of phase-in plant (input) } \\ \text { DISPER } & = & \text { fraction of phase-in plant disallowed (input) } \\ \text { PIBKLF } & = & \text { book life of phase-in plant (input) } \\ \text { ESRR } & = & \text { rate of retum (see Section 1.2) } \\ \text { ESFTXR } & = & \text { federal income tax rate (input) } \\ \text { PITXBS } & = & \text { tax basis as a fraction of book basis for phase-in plant (input) } \\ \text { LPI } & = & \text { length of phase-in plan (input) }\end{array}$

Next, the costs to be deferred in each year are calculated:

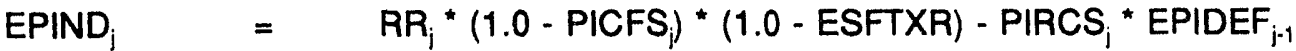

$$
\begin{aligned}
& \text { for } \mathrm{j}=1, \mathrm{LPI}
\end{aligned}
$$

where:

$\begin{array}{lll}\text { EPIND }_{j} & = & \text { pre-tax deferred costs, year } j \\ \text { RR }_{j} & = & \text { traditional revenue requirement of phase-in plant, year } j \\ \text { PIDFS }_{j} & = & \text { cumulative fraction of total cost to be phased-in in year } j \text { (input) } \\ \text { ESFTXR } & = & \text { federal income tax rate (input) } \\ \text { PIRCS }_{j} & = & \text { fraction of remaining deferred revenues to be recovered in year } j \text { (input) } \\ \text { EPIDEF }_{j-1} & = & \text { cumulative deferred costs, year } j-1 \text { (see below). }\end{array}$

Note that EPIND, calculated above, will be positive during the initial period of the phase-in and will be negative during the final period of the phase-in. A negative value represents recovery from rate payers of deferred costs.

Next, the capitalized deferred return is calculated, if necessary (depends on value of IRDPI, an input described above):

$$
\text { EPIRET }_{j} \quad=\quad\left(\text { EPIDEF }_{j-1}+.5^{*} \text { EPIND }_{j}\right)^{*} \text { ESAFDC }_{\text {for }} j=1, \text { LPI }
$$

where: 
41

$\begin{array}{lll}\text { EPIRET }_{j} & = & \text { capitalized return on deferred costs, year } j \\ \text { EPIDEF }_{j-1} & = & \text { cumulative deferred costs, year } j-1 \text { (see below) } \\ \text { EPIND } & = & \text { pre-tax deferred costs, year } j \\ \text { ESAFDC } & = & \text { AFUDC rate (see Section 1.13-a) }\end{array}$

Next, cumulative deferred costs are calculated:

$$
\begin{array}{ll}
\text { EPIDEF }_{j} & =\text { EPIDEF }_{\mathrm{j}-1}+\text { EPIND }_{\mathrm{j}}+\text { EPIRET }_{\mathrm{i}} \\
& \text { for } \mathrm{j}=1, \text { LPI }
\end{array}
$$

where:

$$
\begin{array}{lll}
\text { EPIDEF }_{i} & = & \text { cumulative deferred costs, year } \mathrm{j} \\
\text { EPIND }_{\mathrm{i}} & = & \text { pre-tax deferred costs, year } \mathrm{j} \\
\text { EPIRET }_{\mathrm{j}} & = & \text { capitalized return on deferred costs, year } \mathrm{j}
\end{array}
$$

EPIDEF begins year 1 with a value of 0.0 .

Finally, the net value of disallowed plant is calculated:

$$
\begin{array}{ll}
\text { EDISNT }_{\mathrm{j}} & =\quad \text { PIBKVL * DISPER * }(1.0-\mathrm{j} / \mathrm{PIBKLF}) \\
& \text { for } \mathrm{j}=1, \mathrm{PIBKLF}
\end{array}
$$

where:

$\begin{array}{lll}\text { EDISNT }_{\mathrm{i}} & = & \text { net disallowed plant, year } \mathrm{j} \\ \text { PIBKVL } & = & \text { book value of phase-in plant (input) } \\ \text { DISPER } & = & \text { fraction of phase-in plant disallowed (input) } \\ \text { PIBKLF } & = & \text { book life of phase-in plant (input) }\end{array}$

\subsection{Nuclear Decommissioning}

The cost of decommissioning is read into the EFP and adjusted for assumed rates of inflation to calculate the decommissioning cost in the year of retirement:

NDCost $=\quad$ NDCost * $(1+\text { Inflation })^{\star \star * R e t i r e D a t e ~}$

where:

$\begin{array}{lll}\text { NDCost } & = & \text { the cost to retire the plant in the retirement year } \\ \text { Inflation } & = & \text { the average annual inflation rate to the retirement year } \\ \text { RetireDate } & = & \text { the year of retirement and decommissioning }\end{array}$

The funds needed at the time of retirement are calculated as:

QAmt $=\quad$ NDCost * NDCostF - [NDFund * $(1+\text { NetInt })^{* *}($ Period +1$\left.)\right]$ 
where:

$\begin{array}{lll}\text { QAmt } & = & \text { the funds needed at the time of retirement that have not been collected } \\ \text { NDCostF } & = & \text { escalation assumption for the decommissioning costs } \\ \text { NDFund } & = & \text { current fund balance } \\ \text { Netlnt } & = & \text { return on fund balance (rate of return) } \\ \text { Period } & = & \text { number of years to decommissioning }\end{array}$

The annual addition to the fund is calculated as:

$$
\text { QAmt = QAmt * NetInt } /\left((1+\text { NetInt }){ }^{* \star}(\text { Period }+1)-1\right) /(1-\text { Adminpct })
$$

where:
QAmt $=$ the annual (levelized) additions to the fund (sinking fund)
AdminPct $\quad=$ the cost of administering the fund as a percentage of the fund balance

The total additions with the cost of administering the fund:

$$
\text { QAmt }=\text { QAmt } /(1-\text { AdminPct })
$$

where:

QAmt = the annual contribution to the fund including the cost of administering it

Finally, the ending balance in the decommissioning fund is expressed as:

$$
\text { NDFund } \quad=\quad[\text { NDFund * }(1+\text { Interest }) *(1+\text { Inflation })]+\text { QAmt * NDCollectF }
$$

where:

$$
\begin{array}{lll}
\text { NDFund } & = & \text { the ending balance for the decommissioning fund } \\
\text { NDCollectF } & = & \begin{array}{l}
\text { an assumed regulatory factor expressed as a percentage of the necessary } \\
\text { funds that regulators allow the utility to collect }-1(100 \%) \text { for AEO'94 }
\end{array}
\end{array}
$$

\section{Remaining Algorithms}

Section 1 described in the EFP algorithms to forecast the major components of revenue requirements. This section describes the remaining algorithms which are used to yield forecasts of electric revenues, the price of electricity, taxes (both current and for financial purposes), financial ratios, and other miscellaneous items. 


\subsection{Electric Rovenues}

Electric revenues are a function of revenue requirements and the regulatory lag. Regulatory lag can result from the situation where electric utility rates (and thus revenues) are based on costs from a historical test year rather than on costs from the period during which the rates are in effect. EFP calculates electric revenues under five different assumptions: i) no lag, ii) 1-year lag, iii) one-quarter-year lag, iv) one-halfyear lag, and v) three-quarter-year lag.

In a no-lag scenario, rates are based on current year experiences and rate base so that electric revenues are equal to the revenue requirements calculated in Section 1:

ERRVLG $=$ ERRVRQ

where:

ERRVLG $=$ electric revenues

ERRVRQ = revenue requirements

In a 1-year lag scenario, electric revenues are calculated as follows:

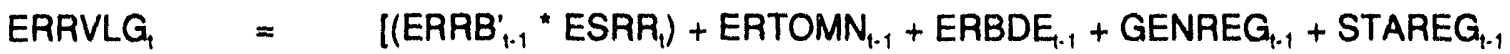
+ FEDREG $_{1-1}-$ EROFFS $_{1-1}+$ ESLLPN $_{1.1}-$ EPIND $_{t \cdot 1]}{ }^{*}$ EQTLSL/EQTLSL $_{1.1}$ + ERTFLN

where variables are same as in Section 1, except:

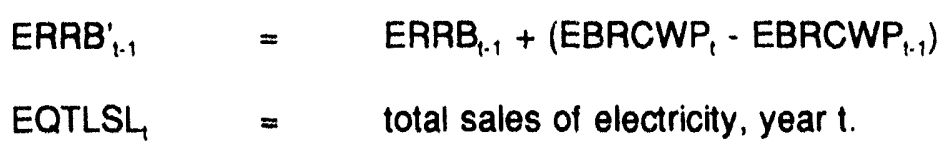

This equation is similar to the equation for revenue requirements presented in Section 1. However, the right-hand variables are lagged by 1 year, with some exceptions. First, the rate base used differs from the previous year's rate base by the difference in the amount of CWIP allowed in rate base. This reflects the fact that the amount of CWIP in rate base is determined by order in each rate case and does not reflect an historically observed value. Similarly, the rate of return on rate base is not the previous year's value, but instead reflects the regulatory commission's current finding on the appropriate return. Next, a factor equal to the ration of current-year sales to previous-year sales is present because the rates are based on historical expenses and sales, but will be collected on the current year sales. Finally, fuel costs are not lagged, but instead recovered as they are incurred. The overall approach is that the price of electricity is comprised of two parts - a fuel cost (recovered through an instantaneously adjusting fuel adjustment clause) and base rates set in rate hearings.

Weighted averages of the revenues under the no-lag and 1-year lag case are used in the other scenarios (e.g., one-half-year lag).

Forecast sales of electricity are passed to EFP from the dispatch module being used to drive EFP. 


\subsection{Allocation of Costs to Customer Classes}

Costs are functionalized by stage of production and classified as capital related, fixed O\&M, variable O\&M, or fuel for each modeled region. Each of these categories may be allocated to the various customer classes using any of the following methods:

\section{2-a Sales Method}

Costs are aliocated on the basis of the proportion of total sales to the class as follows:

DEMFAC $_{\mathrm{i}}=$ SALCLS.JSALTOT

where:

DEMFAC $_{n} \quad=\quad$ the factor for allocating costs to customer class $j$

SALCLS = the total sales of electricity to class $j$

SALTOT = the total sales of electricity to all classes

\section{2-b Coincident Peak Method}

Costs are allocated on the basis of each customer class's contribution to the system peak load:

$$
\text { DEMFAC5 }_{\mathrm{i}}=\text { SECANNUALPEAK1/TOTAL }
$$

where:

$$
\begin{aligned}
& \text { SECANNUALPEAK } 1_{j}=\quad \begin{array}{l}
\text { the load attributable to customer class } j \text { at the time } \\
\text { of the system peak }
\end{array} \\
& \text { TOTAL = the total load on the system at the time of system peak }
\end{aligned}
$$

\section{2-c Probability of Contribution to Peak}

Costs are allocated on the basis of the average contribution to system peak of the customer class over a number of previous model years:

$$
\text { DEMFAC6 }_{\mathrm{i}}=\text { SECANNPEAAVPCP/TOTAL }
$$

where:

$$
\begin{aligned}
& \text { SECANNPEAAVPCP } \mathrm{i}_{\mathrm{i}}=\quad \begin{array}{l}
\text { the average cuntribution to the system peak of customer class } \mathrm{j} \\
\text { over a number of previous model years }
\end{array} \\
& \text { TOTAL } \quad=\quad \begin{array}{l}
\text { the sum of the average contributions to the system peaks of all customer } \\
\text { classes over a number of previous model years }
\end{array}
\end{aligned}
$$

\section{2-d Non-Coincident Peak Method}

In this method, costs are allocated on the basis of the proportion of the load of each customer class at the time of the customer class peak, divided by the sum of the customer class peaks: 
DEMFAC7, = SECANNUALPEAK2/TOTAL

where:

SECANNUALPEAK2

the load of customer class $j$ at the time of the peak load of customer class j

TOTAL = the sum of the customer class loads at the time of the peak for each individual customer class (non-coincident peak)

\section{2- Average and Excess Demand Using Colncident Peak}

Costs are allocated using a combination of the sales method (average demand) and the coincident peak (excess demand). The proportion of costs equal to the level of the system load factor is allocated on the basis of the sales method. The remaining costs are allocated on the basis of the coincident peak method:

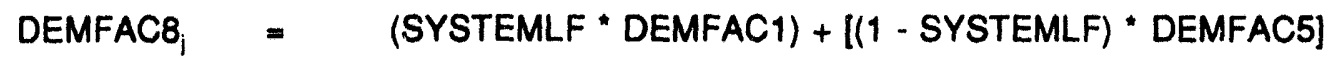

where:

SYSTEMLF = the system load factor

\section{2-f Average and Excess Demand Using Probabllity of Contribution to Peak}

This method is the same as that described above except that the proportion of costs in excess of the system load factor is allocated on the basis of the probability of contribution to peak instead of the coincident peak method:

DEMFAC9 $_{\mathrm{i}}=($ SYSTEMLF * DEMFAC1 $)+[(1-$ SYSTEMLF $) *$ DEMFAC6 $]$

\section{2-g Allocation of Costs to Customer Classes}

Finally, all of the methods used for allocating each cost category (each cost fype - capital, fuel, etc.- by stage of production) are summed for each of those cost categories:

$$
\operatorname{COSTFC}_{k \mathrm{j}}=\sum \text { DEMFAC }_{n j} \text { TECFAC }_{n k l}
$$

where:

\begin{tabular}{|c|c|c|}
\hline $\operatorname{cosTFC}_{k j l}$ & $=$ & $\begin{array}{l}\text { Im of all allocation proportions for cost type } k \text {, customer class } \mathrm{j} \text {, and } \\
\text { of production I }\end{array}$ \\
\hline $\begin{array}{l}\text { DEMFAC } \\
\text { TECFAC }\end{array}$ & & $\begin{array}{l}\text { i proportion using method } n \text { for customer class } j \\
\text { ortion of cost type } k \text { to be allocated using method }\end{array}$ \\
\hline
\end{tabular}

and revenues are allocated to the class:

$$
\operatorname{REV}_{j 1} \quad=\quad \operatorname{COSTFC}_{k j l} * \operatorname{COST}_{k l}
$$

where: 


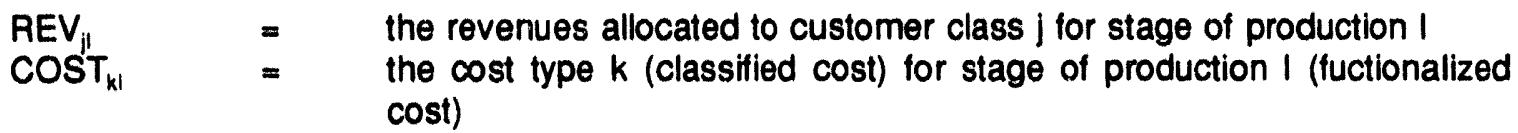

\subsection{Price of Electricity}

With electric revenues forecast and allocated, the forecast price of electricity is straightforward:

\section{3-a Price Calculation}

$$
\text { EPRICE }_{\mathrm{jl}} \quad=\quad \text { REV }_{\mathrm{j}} / \mathrm{SALCLS}_{\mathrm{i}}
$$

where:

$\begin{array}{lll}\text { EPRICE }_{\mathrm{il}} & = & \text { the price of electricity for customer class } j \text { and stage of production I } \\ \text { REV }_{j 1} & =\quad \text { electric revenues allocated to customer } \\ \text { SALCLS } & =\text { sales to customer }\end{array}$

\section{3-b Benchmark/Subsidization Calculation}

Once the price of electricity has been calculated for each customer class and region at the distribution stage of production, the computed prices for residential, commercial, and transportation are compared to historic prices for benchmarking and subsidy calculation ${ }^{24}$. The prices for transportation are not benchmarked because (1) there is no relevant historic price for off-peak electric vehicles, and (2) the proportion of costs allocated to this class is very small. Differences in the modelled prices and historic prices may be due to differences between the modelled allocation techniques and those being used in practice, and they may be due to customer class cross-subsidization where one customer class's cost allocation is increased or decreased for the purpose of accommodating another class. This benchmarking/subsidization routine is as follows:

First, the historic and modelled proportions of revenues to each of the three classes are determined. Historic proportions are:

$$
\text { REVHPCT }_{\text {iY }}=\text { REVYj/REVHRCI }
$$

\begin{tabular}{|c|c|c|}
\hline $\begin{array}{l}\text { REVHPCT } \\
\text { REVY }_{j} \\
\text { REVHRCI }_{y}\end{array}$ & $=$ & $\begin{array}{l}\text { the actual proportion of revenues allocated to customer class } j \text { in year } y \\
\text { the actual revenues allocated to customer class } j \text { in year } y \\
\text { the actual total revenues allocated to all three classes in year } y\end{array}$ \\
\hline
\end{tabular}

where:

\footnotetext{
${ }^{24}$ This benchmarking/subsidization technique is not used for the generation or transmission transfer price calculations.
} 
The modelled proportions are:

$$
\text { REVPCT }_{\mathrm{jy}}=\mathrm{REV}_{\mathrm{j} \mathrm{j}} / \mathrm{REVRCl}_{\mathrm{y}}
$$

where:

$\begin{array}{lll}\text { REVPCT }_{\text {iy }} & = & \text { the modelled proportion of revenues allocated to customer class } j \text { in year } \\ \text { REV }_{y} & = & \text { the modelled revenues allocated to customer class } j \text { in year } y \\ \text { REVRCI }_{y} & = & \text { the modelled total revenues allocated to all three classes in year } y\end{array}$

The historic proportion of sales attributable to each customer class is:

$$
\text { SLSHPCT }_{\text {iy }}=\text { SALYj/SLSHRCI }
$$

where:

$\begin{array}{lll}\text { SLSHPCT }_{i y} & = & \text { the actual proportion of sales to customer class } j \\ \text { SALY }_{j} & =\quad \text { the actual sales to customer class } j \text { in year } y \\ \text { SLSHRCI }_{y} & = & \text { the actual sales to all three classes in year } j\end{array}$

The modelled proportion of sales is:

$$
\text { SLSPCT }_{i y} \quad=\quad \text { SALCLS }_{i \gamma} / \text { SLSRCI }_{y}
$$

where:

$$
\begin{array}{lll}
\text { SLSPCT }_{\text {iy }} & = & \text { the modelled proportion of sales to customer class } j \\
\text { SALCLS }_{i y} & = & \text { the modelled sales to customer class } j \text { in year } y \\
\text { SLSRCl }_{y} & = & \text { the modelled sales to all three classes in year } j
\end{array}
$$

These ratios are then used to calculate the implied subsidy to be used to benchmark/subsidize customer class prices while controlling for differences in the level of actual sales to each customer class and modelled sales to each customer class.

$$
\text { SUBPCT }_{i}=\left(\text { REVHPCT }_{i}-\mathrm{SLSHPCT}_{j}\right)-\left(\text { REVPCT }_{i}-\mathrm{SLSPCT}_{i}\right)
$$

\section{3-c Calculation of Prices with Benchmarking and Subsidization}

After the benchmarking/subsidization proportion has been calculated, it is multiplied times the total revenues allocated to the three benchmarked/subsidized customer classes to determine the revised allocation to each class. This revised allocation is again divided by sales to the class to determine the revised price:

$$
\text { EPRICE }_{j}=\left(\text { REV }_{j}+\left(\text { REVRCI }^{\prime} \text { SUBPCT }_{j}\right)\right) /\left(\text { SALCLS }_{j}\right)
$$

where:

$$
\begin{aligned}
& \text { EPRICE } \quad=\text { the benchmarked/subsidized price of electricity to customer class } j \\
& \text { REV }_{\mathrm{i}} \quad=\text { the costs (revenues) allocated to customer class } j \text { before the } \\
& \text { benchmarking/subsidization routine }
\end{aligned}
$$




$\begin{array}{lll}\text { REVRCI } & = & \text { totel costs allocated to the three customer classes } \\ \text { SUBPCT }_{j} & = & \text { benchmarking/subsidy percent for customer class } \mathrm{j} \\ \text { SALCLS }_{\mathrm{j}} & = & \text { electricity sales to customer class } \mathrm{j}\end{array}$

\subsection{Taxes}

EFP calculates two categories of taxes: general taxes and income taxes.

\section{4-a General Taxes}

General taxes encompass all taxes except the State and Federal income taxes. Among these taxes are gross receipts, FICA, capitalized payroll, property and sales.

The assumption is made that these taxes each year will be a constant percentage of revenues.

GENTAX = EGTXRT * ERRVLG + ERPRTX + ERSLTX

where:

$\begin{array}{lll}\text { GENTAX } & = & \text { actual general taxes } \\ \text { EGTXRT } & = & \text { general tax rate (user input) } \\ \text { ERRVLG } & = & \text { electric revenues (see Section 2.1) } \\ \text { ERPRTX } & = & \text { property taxes (see Section 1.6) } \\ \text { ERSLTX } & = & \text { sales tax (see Section 1.6) }\end{array}$

ERPRTX is modeled as an input fraction of the book value of property, and ERSLTX is modeled as an input fraction of the construction expenditures.

\section{4-b Income Taxes}

Current income taxes are those actually paid by the utility in a given year. Because of the regulatory and financial treatment of certain tax savings (e.g., investment tax credits, accelerated depreciation), this is not, in general, what is booked on the income statement as income tax expense.

CITAX $=\quad$ (ERRVLG - ERTFLN - ERTOMN - ERTDWO - GENTAX - (ERTIEX - AVDINT) ESLLP) * ESFTXR + STTAX - (ERFITC + XITCD) - (ERATSF + ERATSD)

where:

$\begin{array}{lll}\text { CITAX } & = & \text { current income taxes } \\ \text { ERRVLG } & = & \text { electric revenues (see Section 2.1) } \\ \text { ERTFLN } & = & \text { fuel costs (see Section 1.3) } \\ \text { ERTOMN } & = & \text { operation and maintenance expenses, excluding fuel (see Section 1.4) } \\ \text { ERTDWO } & = & \text { depreciation for tax purposes, without acceleration (see Section 1.14-b) } \\ \text { GENTAX } & = & \text { actual general taxes (see Section 2.3-a) } \\ \text { ERTIEX } & = & \text { interest expenses (see Section 1.7-a) } \\ \text { AVDINT } & = & \text { interest capitalized on assets during construction (see Section 1.13-d) } \\ \text { ESLLP } & = & \text { annual lease payment associated with sale/leaseback transactions } \\ \text { ESFTXR } & = & \text { Federal income tax rate (user input) }\end{array}$




$\begin{array}{lll}\text { STTAX } & = & \text { State income taxes, including Federal income tax benefits (see below) } \\ \text { ERFITC } & = & \text { generated ITC which is flowed through (see Section 1.15) } \\ \text { XITCD } & =\text { generated ITC that is deferred (see Section 1.15) } \\ \text { ERATSF } & = & \text { tax savings from accelerated depreciation that is flowed through (see } \\ & \text { Section 1.14-b) } \\ \text { ERATSD } & = & \text { tax savings from accelerated depreciation that is deferred (see Section } \\ & 1.14-\mathrm{b}) .\end{array}$

Now, booked income tax expense is current taxes, plus deferrals, minus amortizations:

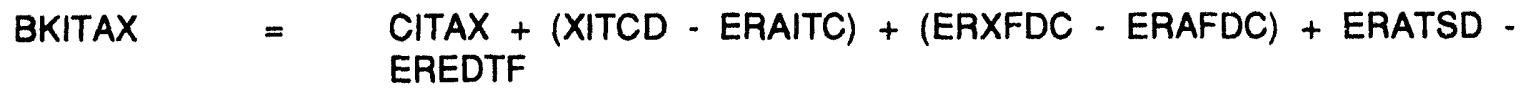

where:

$\begin{array}{lll}\text { BKITAX } & = & \text { booked income tax expense } \\ \text { ERAITC } & = & \text { amortization of deferred ITC (see Section 1.15) } \\ \text { ERXFDC } & = & \begin{array}{l}\text { generated tax savings from debt portion of AFUDC that is deferred (see } \\ \text { Section 1.13-d) }\end{array} \\ \text { ERAFDC } & = & \begin{array}{l}\text { amortization of deferred tax savings from the debt portion of AFUDC (see } \\ \text { Section 1.13-d) }\end{array} \\ \text { EREDTF } & = & \text { excess deferred taxes flowed back to rate payers. }\end{array}$

The only remaining tax variable to be explained is STTAX (State income taxes including Federal income tax benefits):

$$
\begin{array}{ll}
\text { STTAX }= & \text { (ERRVLG - ERTFLN - ERTOMN - ERTDWO - ERTIEX - ESLLP) * } \\
\text { ESSTXR* } & (1-\text { ESFTXR })
\end{array}
$$

where:

ESSTXR $=$ State income tax rate (user input).

State income taxes are deductible in calculating Federal taxable income so the net effect of State income taxes upon total income taxes is STTAX.

\subsection{Financial Ratios}

The output of EFP includes the forecasted values of several financial ratios. These ratios are standard indicators of a utility company's financial health. However, financial analysts disagree over the exact formula to be used in some cases. For EFP, the following definitions are used:

i) Interest Coverage. Interest coverage is calculated and printed under four alternative formulas. In all formulas, the denominator is total interest expenses. For pre-tax interest coverage, less AFUDC, the numerator is operating income plus booked income taxes. For pre-tax interest coverage, with AFUDC, the numerator is operating income, plus booked income taxes, plus AFUDC. For post-tax interest coverage, less AFUDC, the numerator is operating income. For post-tax interest coverage, with AFUDC, the numerator is operating income plus AFUDC.

ii) Actual Return on Common Equity. This ratio is calculated as eamings available for common equity 
divided by the year-average book value of common equity (common stock plus retained earnings).

iii) AFUDC as a Percentage of Earnings Available for Common. This ratio is calculated AFUDC divided by earnings available for common equity.

iv) Internal Cash Flow as a Percent of Construction Expenditures. This ratio is calculated as total internally generated funds divided by construction expenditures (excluding AFUDC).

v) CWIP as a Percentage of Net Plant. This ratio is calculated as total CWIP divided by net plant. Net plant includes both plant in service and CWIP.

vi) Effective Tax Rate. This rate is calculated as booked income taxes divided by booked pre-tax income. Pre-tax income is the sum of operating income and booked income taxes.

vii) Safety Margin. This ratio is calculated as net income plus booked income taxes, minus AFUDC, all divided by electric revenues. 


\section{Appendix A \\ Listing of Subroutines and Subroutine Functions ${ }^{25}$.}

The following list provides a brief description of the subroutines in the EFP. Line numbers from the code are included to help the user find appropriate subroutines and make changes as necessary. Also, this section provides insights for a better understanding of the operation of the EFP.

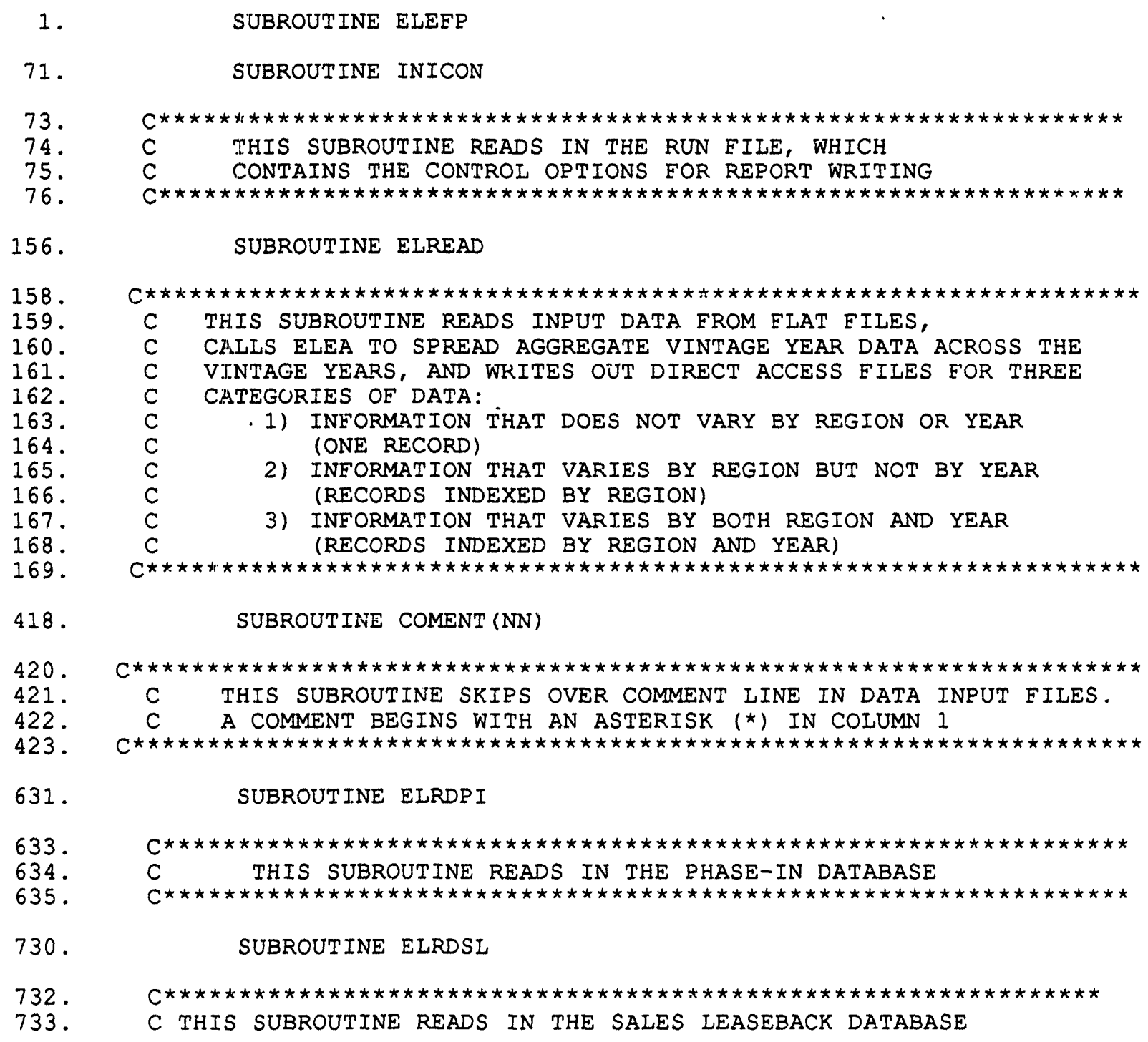

${ }^{25}$ All listings of code in this section are from CN6005.PRJ.NEMS.FORTRN.UEFP.D1123931. 
734.

784.

786.

787.

788 .

789 .

884.

886. 887.

888 .

889.

890.

891.

892.

893.

894.

895.

965.

967.

968 .

969 .

1004.

1006.

1007.

1008 .

1046 .

1049.

1050 .

1051.

1052.

1053.

1054.

1500 .

1502.

1503 .

1504 .

1505.

1506 .

1507.

1508 .

1509.

1510 .

1511.

1512 .

1540.

1542.

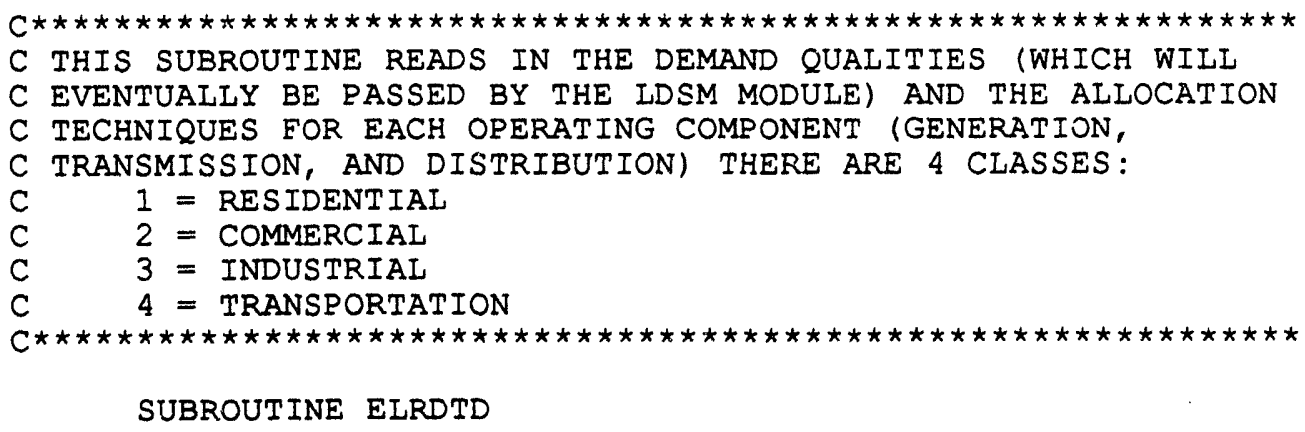

\section{SUBROUTINE ELEA}

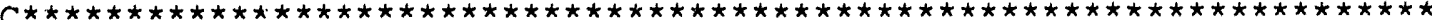 C THIS SUBROUTINE CALCULATES ACCOUNTS FOR EXISTING ASSETS INCLUDING C BOOK VALUE, ASSET VALUE, ACCUMULATED BOOK DEPRECIATION, AMORTI-
C ZATION OF DEFERRED INVESTMENT TAX CREDITS, AND AMORTIZATION C OF DEFERRED TAX SAVINGS FROM THE DEBT PORTION OF AFUDC

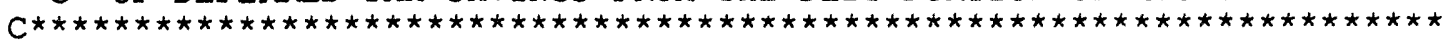
SUBROUTINE EFP (NRGN)

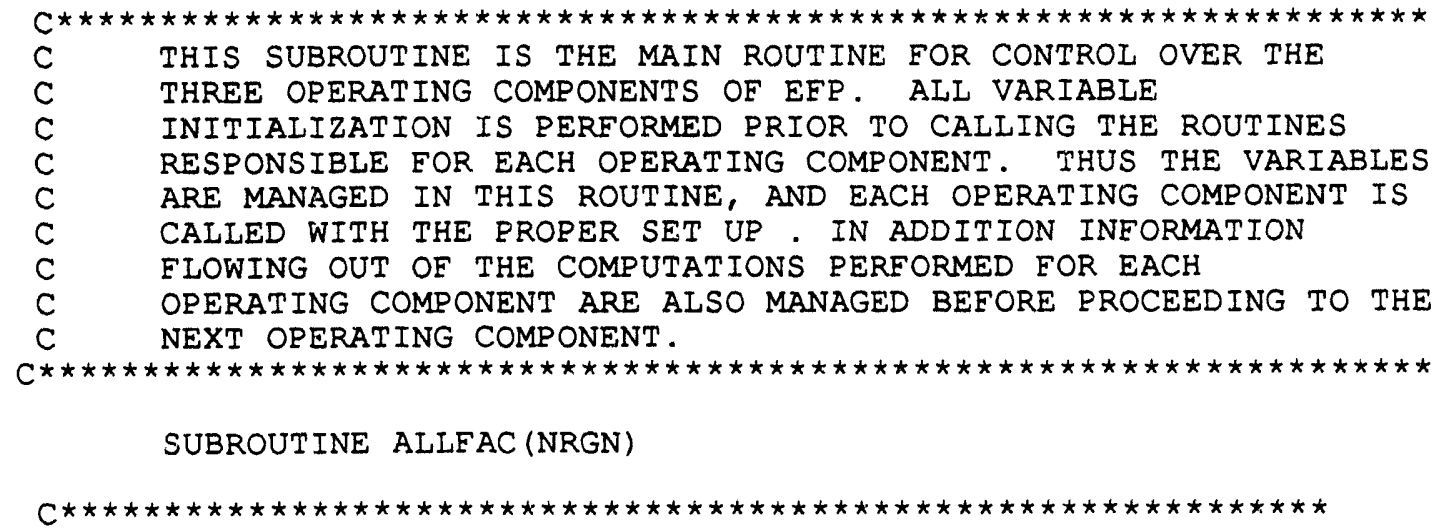




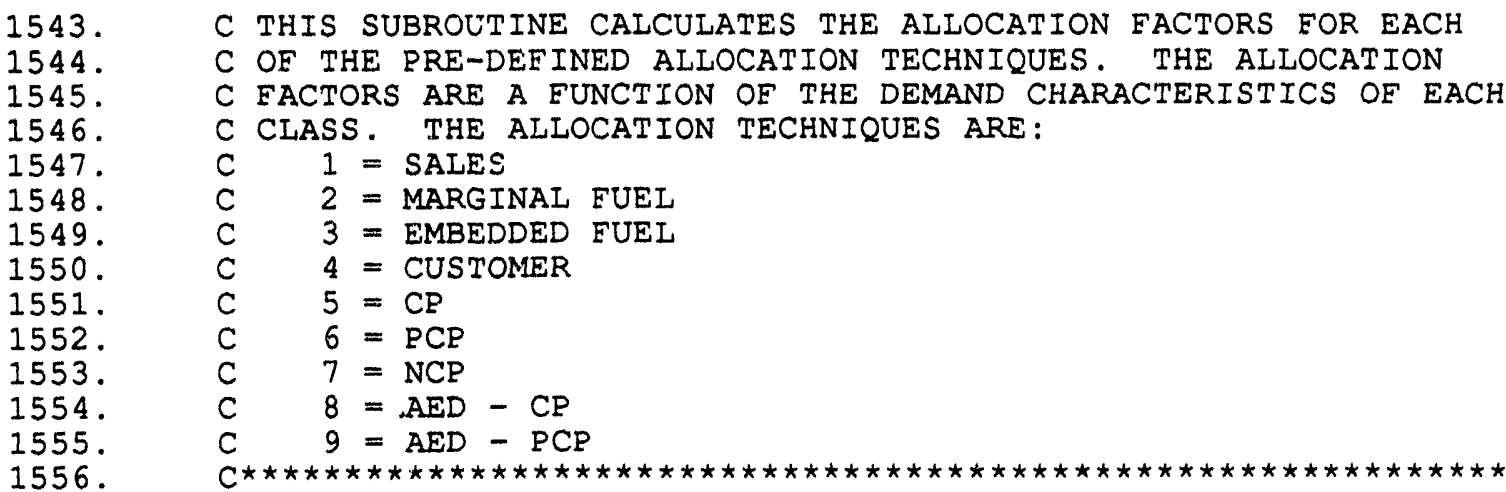

1690. SUBROUTINE ELGLTR (NRGN, ICALL)

1692 .

1693.

1694.

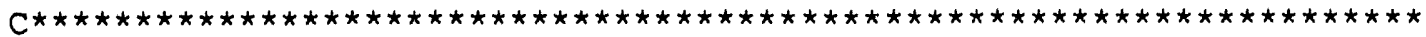
C THIS SUBROUTINE TRANSEERS GLOBAL TO LOCAL VARIABIES

1896.

SUBROUTINE EIIGTR (NRGN, ICALI)

1898.

1899.

1900 .

2050 .

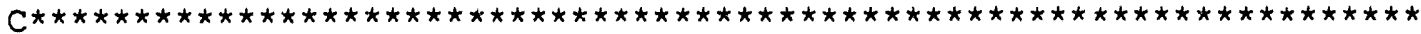

2052 .

2053 .

2054 .

2272 .

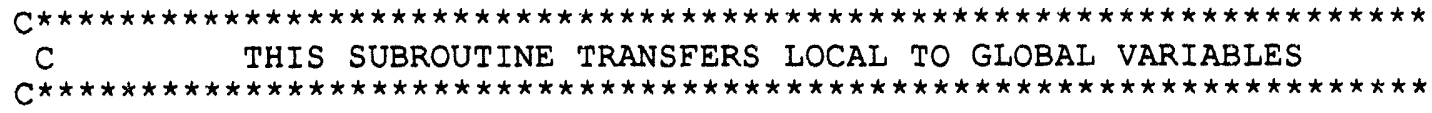

2274.

2275 .

2276 .

2277 .

2348 .

SUBROUTINE CAPCOST (NRGN, ICALL, CURIYR, CURITR, N)

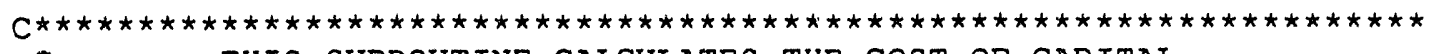
C THIS SUBROUTINE CALCULATES THE COST OF CAP ITAL

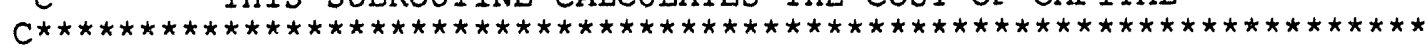
SUBROUTINE ELDIST (NRGN)

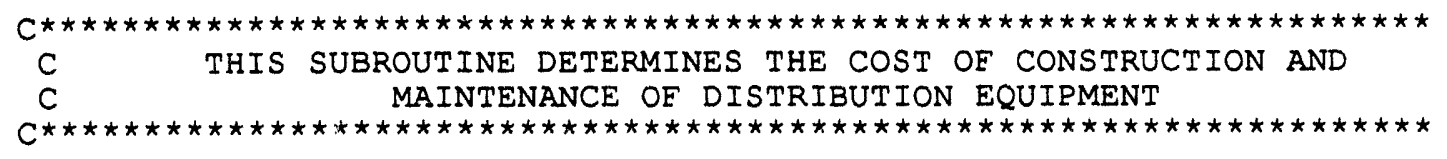
SUBROUTINE ELTRAN (NRGN)

2350 . 2351.

2352 .

2353.

2515 .

2517 . 2518 .

2519 .

2520 .

2587 .

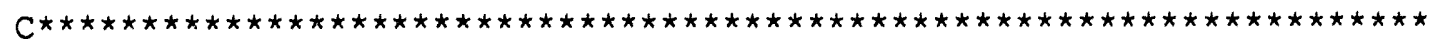
C THIS SUBROUTINE DETERMINES THE COST OF CONSTRUCTION AND C MAINTENANCE OF TRANSMISSION EQUIPMENT

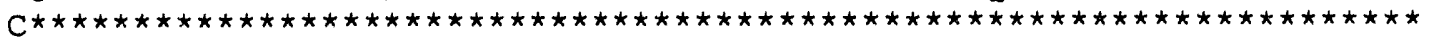

2589 .

2590 .

2591.

SUBROUTINE GL (NRGN, ICALL)

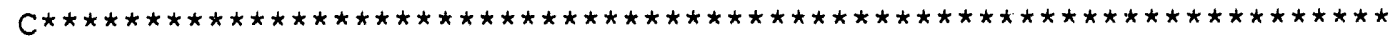

C THIS SUBROUTINE GATHERS INEORMATION NEEDED FROM THE

C DISPATCH PART OE NEMS

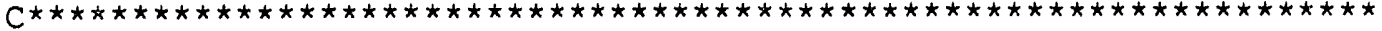

SUBROUTINE GENERA (NRGN, ICALI)

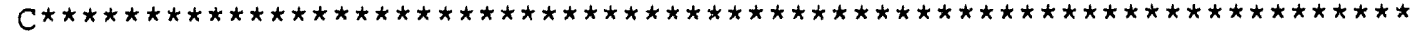

C THIS SUBROUTINE INVOKES GENERATION ACCOUNTING COMPUTATIONS

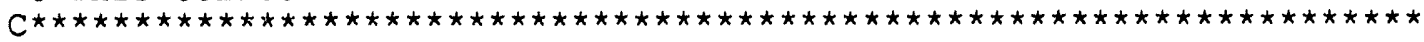

Electricity Finance and Pricing Submodule Documentation - April 1994 
2601.

2603.

2604.

2605 .

2633.

2635.

2636 .

2637 .

2638 .

2692.

2694.

2695.

2696 .

2697.

2980.

2982.

2983.

2984 .

2985.

3153.

3155.

3156 .

3157 .

3158 .

3159 .

3160 .

3338.

3340 .

3341 .

3342 .

3343 .

3455 .

3457 .

3458 .

3459 .

3460 .

3530 .

3532 .

3533 .

3534 .

3535 .

3536 .

3537 .

3718 .

SUBROUTINE AVRPRC (NRGN, ICALL)

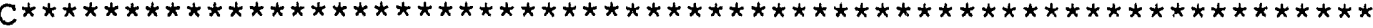
C THIS SUBROUTINE INVOKES AVERAGE COST PRICING COMPUTATIONS

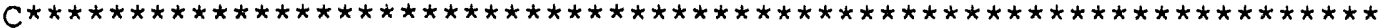

SUBROUTINE ELADCR

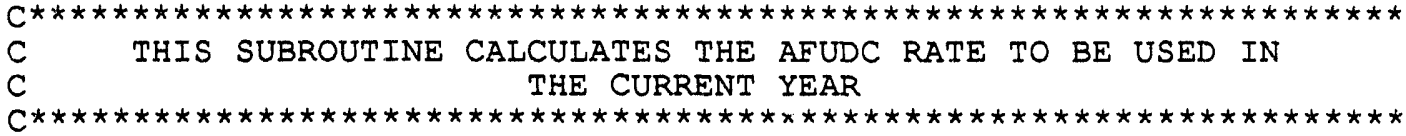

SUBROUTINE ELCWIP (NRGN, ICALL)

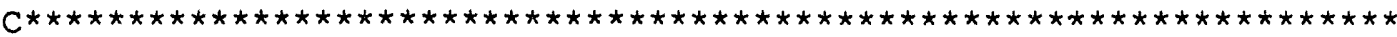
C THIS SUBROUTINE CALCULATES THE FINANCIAI ACCOUNTS RELATED C TO CONSTRUCTION WORK IN PROGRESS

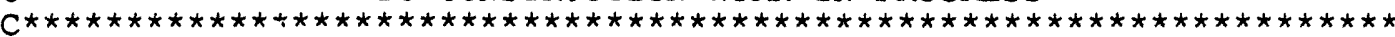

SUBROUTINE ELBKDP

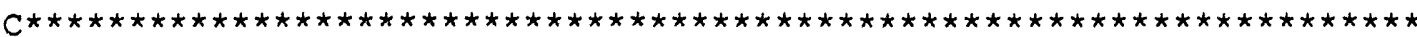
C THIS SUBROUTINE CALCULATES BOOK DEPRECIATION AND TAX C DEPRECIATION WITHOUT ACCEIERATION

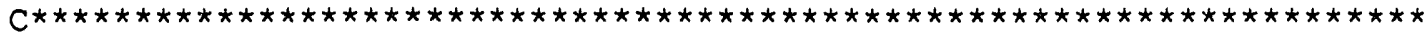

SUBROUTINE ELTXDP

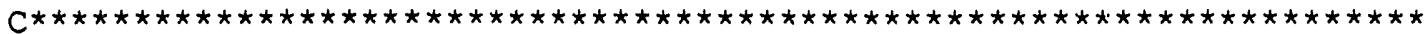
C THIS SUBROUTINE CALCULATES TAX DEPRECIATION USING:

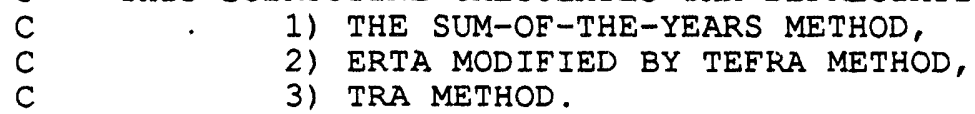

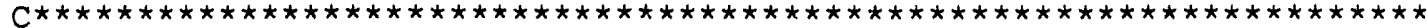

SUBROUTINE ELITC

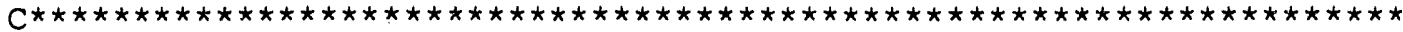
C THIS SUBROUTINE CALCULATES THE ACCOUNTS RELATING TO THE C INVESTMENT TAX CREDIT

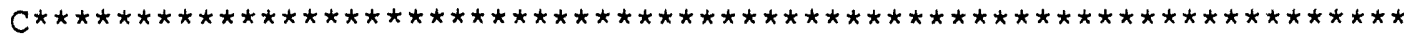
SUBROUTINE EITSAF

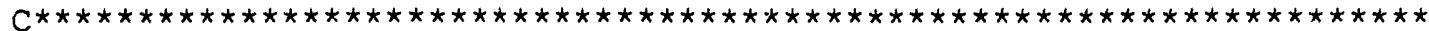
C THIS SUBROUTINE CALCULATES THE ACCOUNTS REIATING TO THE TAX C SAVINGS FROM THE DEBT PORTION OF AFUDC

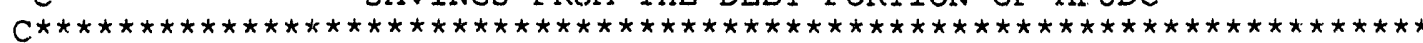
SUBROUTINE ELEDT (NRGN)

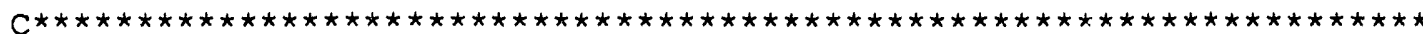

C CALCULATE EXCESS DEFERRED TAXES FROM ACCEIERATED DEPRECIATION

C THAT RESULT FROM THE LOWERING OF THE FEDERAL INCOME TAX RATE.

C ALSO CALCULATE HOW MUCH OE THIS EXCESS SHOULD BE ELOWED THRU TO

$C$ CUSTOMERS IN EACH YEAR OF THE FORECAST PERIOD.

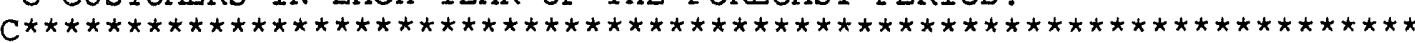

SUBROUTINE SYD (ICYOS, DEPR, TXLE, BKLE, EXCESS, FT, NYRSET, ETPER)

Electricity Finance and Pricing Submodule Documentation - April 1994 
3720.

3721 .

3722 .

3723.

3724 .

3725 .

3726 .

3727 .

3804 .

3806 .

3807 .

3808 .

3809 .

3810 .

3811 .

3812 .

3813 .

3889.

3891.

3892 .

3893 .

3894 .

3895 .

3896 .

3897 .

3898 .

3962 .

3964. 3965. 3966 . 3967 . 3968 .

3969 .

4035.

4037 .

4038 .

4039 .

4040 .

4041 .

4042 .

4043 .

4044 .

4045 .

4207.

4209. 4210 . 4211. 4212 . 4213 . 421.4

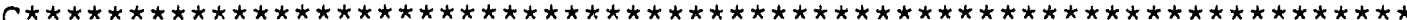

C THE PURPOSE OF THIS SUBROUTINE IS TO CALCULATE THE AMOUNT OF

C 'EXCESS' DEFERRED TAXES WHICH MUST BE FLOWED BACK TO RATE PAYERS.

C THE 'EXCESS' DEFERRED TAXES ARE THOSE WHICH WERE BOOKED AT 46\%

C BUT WILL NEVER BE AMORTIZED OTHERWISE BECAUSE OF THE LOWERED TAX

C RATE. THIS ROUTINE IS EOR THOSE ASSETS WHICH HAVE USED SUM OF C THE YEARS DIGITS.

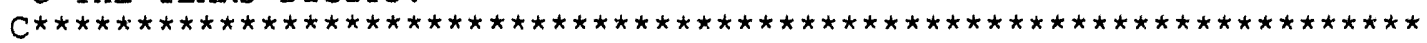

SUBROUTINE ERTA (ICYOS, DEPR, IPTYP, EXCESS, BKLF, ET, NYRSFT, ETPER)
C THE PURPOSE OF THIS SUBROUTINE IS TO CALCULATE THE AMOUNT OF
C 'EXCESS' DEFERRED TAXES WHICH MUST BE FLOWED BACK TO RATE PAYERS.
C THE 'EXCESS' DEFERRED TAXES ARE THOSE WHICH WERE BOOKED AT $46 \%$
C BUT WILL NEVER BE AMORTIZED OTHERWISE BECAUSE OF THE LOWERED TAX
C RATE. THIS ROUTINE IS FOR THOSE ASSETS WHICH HAVE USED THE ERTA
C TAX SCHEDULES.

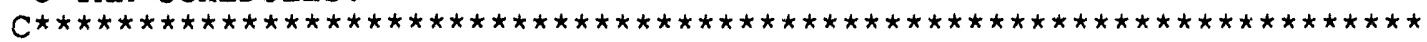

SUBROUTINE CONDRS (ICYOS, DEPR, J, EXCESS, BKLF, ET, NYRSFT)

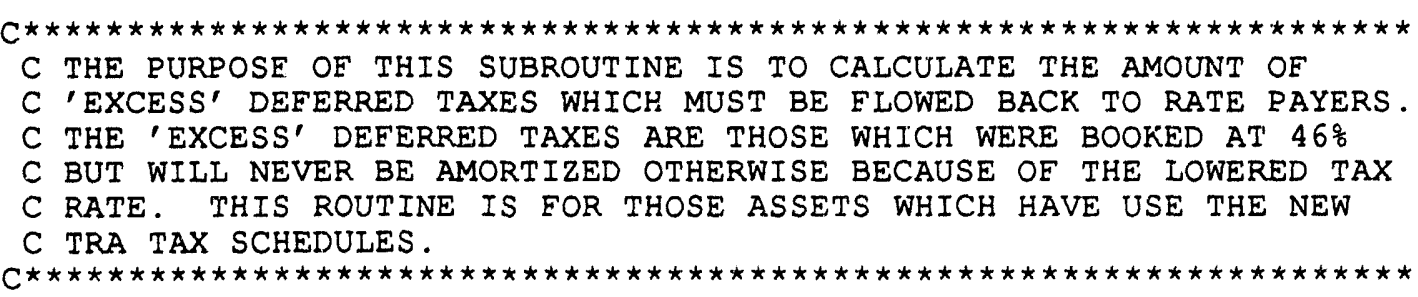
SUBROUTINE FTEDT (EXCESS, LYEAR, NRGN, FT, NYRSET)

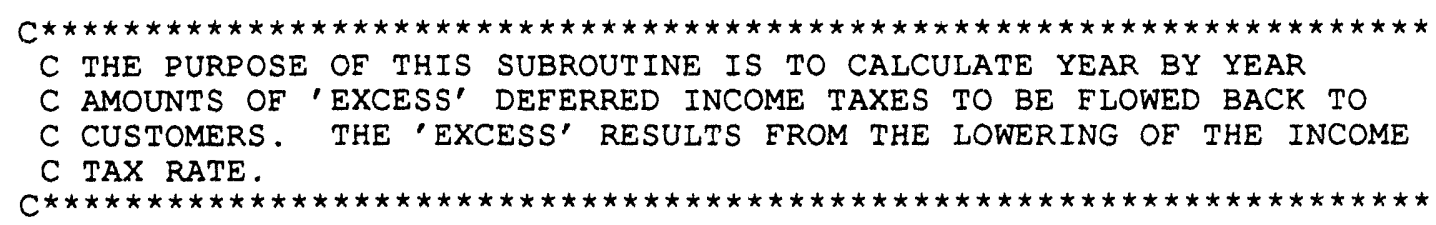
SUBROUTINE ELPHIN (NRGN)

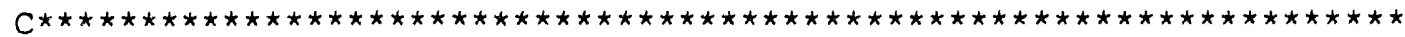

C

- ELPHIN -

C THIS SUBROUTINE CALCULATES THE IMPACT OF PHASE-IN/DISALLOWANCE

C PLANS OF NEW CAPACITY. SINCE THE REST OE THE MODEL HAS

C CALCULATED COMPONENTS OF REVENUE REQUIREMENTS ASSUMING

C TRADITIONAL REGULATORY TREATMENT OF THESE PLANTS, THIS ROUTINE

C ONLY CALCULATES THE CHANGE IN THE COMPONENTS CAUSED BY THE PHASE

C IN PIAN, RELATIVE TO TRADITIONAL REGULATION.

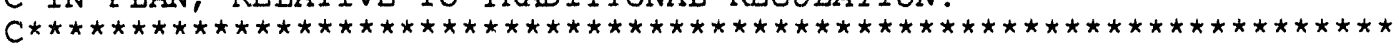

SUBROUTINE ELPIPY (I, IPI)
C
-ELPIPY -
C THIS SUBROUTINE CALCULATES THE IMPACT OF PHASE-IN/DISALIOWANCE
C PLANS OF NEW CAPACITY FOR YEA:RS BEFORE THE MODEL STARTS. THIS
C SUBROUTINE WORKS EXACTLY THE SAIF, WAY AS THE SUBROUTINE ELPHIN
C WHICH CALLS THIS SUBROUTINE. 
4215 .

SUBROUTINE ELSL(NRGN)

4336 .

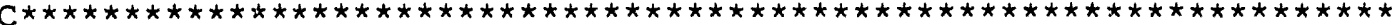

4338 .

4339

4340 .

4341 .

4342 .

4343 .

4344 .

4345 .

4346 .

4347 .

4348 .

4349 .

4349.1

4444. FUNCTION ELCEXP (JYR, LCP)

C THIS SUBROUTINE ADJUSTS THE RESULTS OF EFP FOR THE IMPACT OF

$C$ SALES AND SUBSEQUENT LEASEBACK OF UTILITY PLANT. IN ORDER TO

C CONSERVE SPACE AND NOT PRODUCE ANY ADDITIONAL BUILDS, THE MOST

C RECENT DISTRIBUTION BUILD IS ADJUSTED TO REFLECT IMPACT. THIS

C SUBROUTINE RELIES ON 2 SIMPLIFICATIONS:

C (1) EVEN THOUGH THE ALGORITHM ASSUMES THAT PROCEEDS EROM SALE

C ARE USED TO RETIRE HIGH COST DEBT AND EQUITY, NO SPECIAL

C ADJUSTMENTS ARE MADE TO THE EMBEDDED INTEREST RATES,

C (2) THE TAX ON THE GAIN IS NOT REFLECTED IN THE CURRENT INCOME TAX CALCULATIONS, BUT RATHER THE ALGORITHM USES THE AFTER TAX GAIN (THIS STILL PRODUCES CORRECT RESULTS).

4446 .

4447 .

4448 .

4449 .

4450 .

4475 .

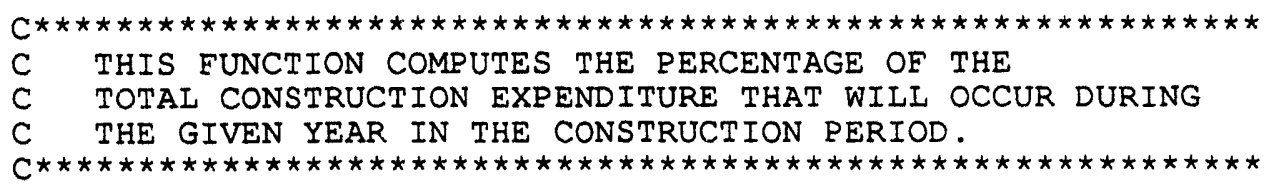

SUBROUTINE ELXPNS (NRGN, ICALL)

4477 .

4478 .

4479 .

4480 .

4528 .

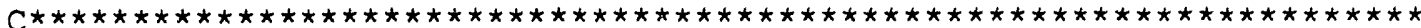 C THIS SUBROUTINE CAICULATES NOMINAI FUEI AND O\&M EXPENSES, AND C WORKING CAPITAI

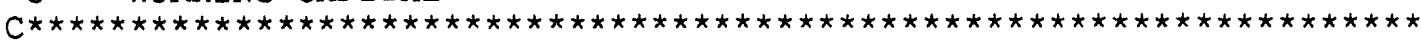

4530 .

4531 .

4532 .

SUBROUTINE ELINEX(NRGN)

4665 .

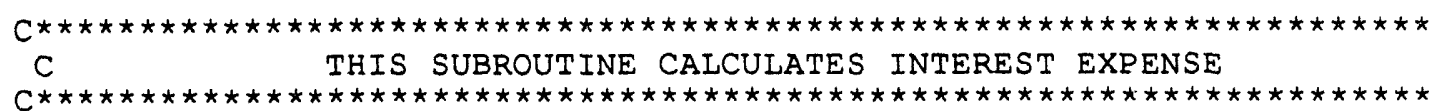

4667 .

4668 .

4669 .

4670 .

\section{SUBROUTINE ELREVS}

4901 .

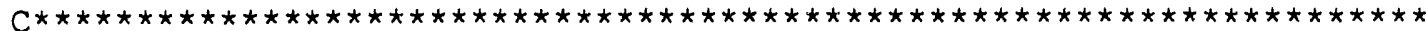
C THIS SUBROUTINE SOLVES FOR THE REVENUE REQUIREMENTS AND THEN C DETERMINES ALLOWED REVENUES BASED ON THE REGULATORY LAG.

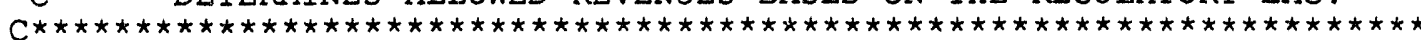

SUBROUTINE STMTS (NRGN, ICALI)

4903.

4904 .

4905 .

C THIS SUBROUTINE PREPARES THE FINANCIAI STATEMENTS.

5331.

SUBROUTINE ELRATE (ICALL, NRGN)

5333.

5334.

5335 .

5336 .

5337 .

5338 .

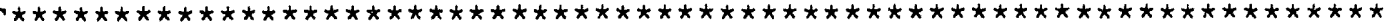
C THIS SUBROUTINE CONTROLS THE CALCULATION OF RATES BY SECTOR.

C IT UTILIZES 3 SUBROUTINES:
C FUNCTN: FUNCTIONALIZES TOTAL COSTS INTO CATEGORIES

C ALLOCT: ALLOCATES CATEGORY COSTS TO CLASSES

C RATES: CALCULATES AVERAGE PRICE FOR EACH CLASS

Electricity Finance and Pricing Submodule Documentation - April 1994 
5339.

5368

5370 .

5371.

5372 .

5373 .

5374 .

5375 .

5376 .

5377.

5409 .

5411.

5412.

5413 .

5445 .

5447.

5448 .

5449 .

5450 .

5451 .

5681.

5683.

5684 .

5685 .

5695.

5697.

5698 .

5699 .

5709.

5711. 5712.

5713.

5714.

5715.

5754.

5756.

5757.

5758.

5759.

5760 .

5815.

5817. 5818. 5819 .

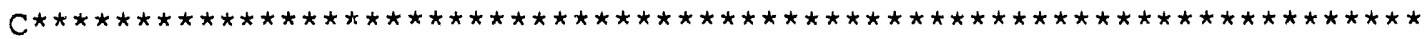
SUBROUTINE EUNCTN (ISECT, NRGN)

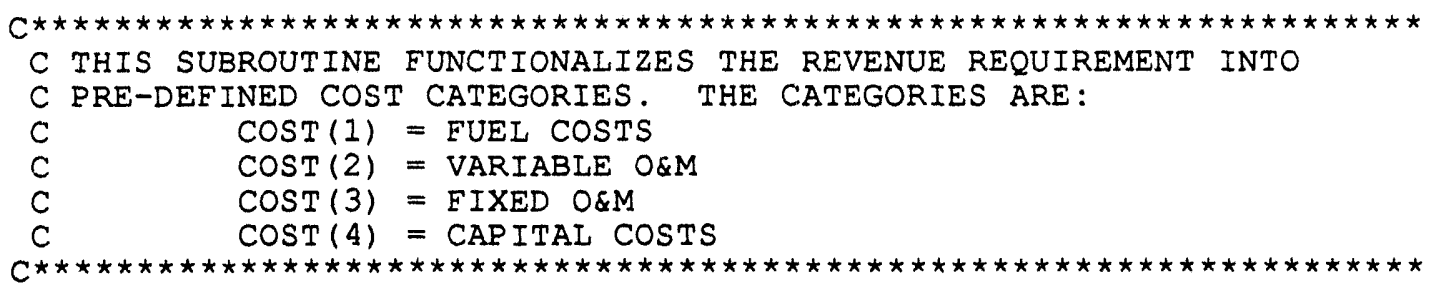
SUBROUTINE ALLOCT (ISECT)

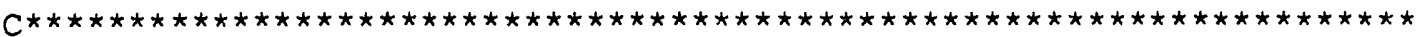
C THIS SUBROUTINE CALCULATES REVENUES ALLOCATED TO EACH CLASS

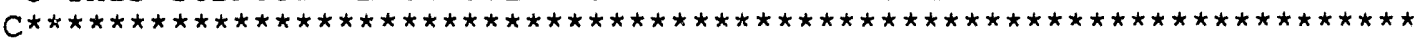
SUBROUTINE RATES (ISECT, NRGN)

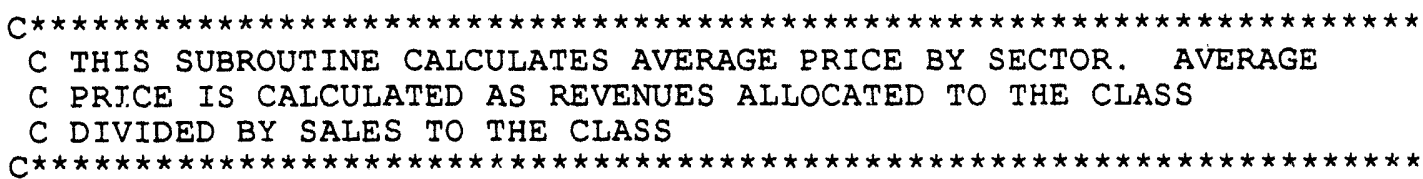
SUBROUTINE TRANSM(NRGN, ICALL)

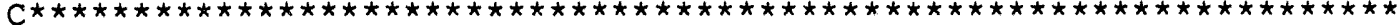
C THIS SUBROUTINE INVOKES TRANSMISSION ACCOUNTING COMPUTATIONS

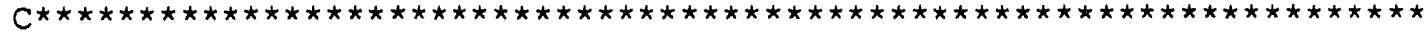

SUBROUTINE DISTRI (NRGN, ICALL)

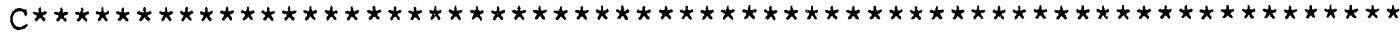
C THIS SUBROUTINE INVOKES DISTRIBUTION ACCOUNTING COMPUTATIONS

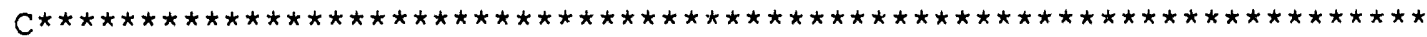

SUBROUTINE GETEB (NRGN, ICALI)

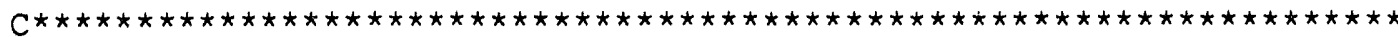
C THIS SUBROUTINE CREATES ARRAYS (THE EB ARRAYS) WHICH CONTAIN

C PARAMETERS DESCRIBING EACH BUILD APPIICABLE TO THE CURRENT

C REGION AND OPERATING COMPONENT (TRANS, DIST, OR GENERATION).

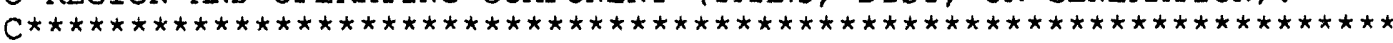

SUBROUTINE STREB (NRGN, ICALL)

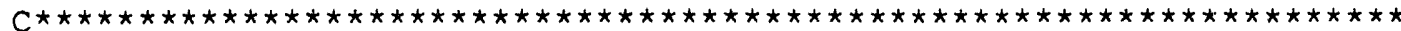

C THIS SUBROUTINE CREATES ARRAYS (THE EB ARRAYS) WHICH CONTAIN

C PARAMETERS DESCRIBING EACH BUILD APPIICABLE TO THE CURRENT

C REGION AND ORERATING COMPONENT (TRANS, DIST, OR GENERATION).

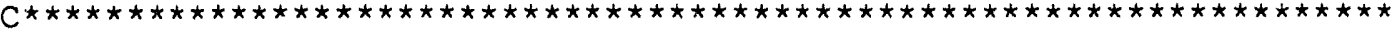

SUBROUTINE ELSET

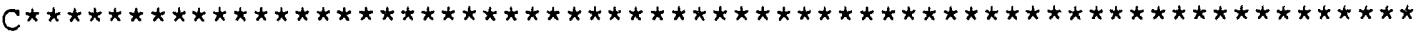

C THIS SUBROUTINE ASSIGNS ELECTRICITY PRICES BY SECIOR AND REGION C USING A MAPPING FROM NERC TO CENSUS REGIONS

Electricity Finance and Pricing Submodule Documentation - April 1994 
5820.

6083

6085 .

6086 .

6087.

6088 .

6145.

6147.

6148.

6149.

6150 .

6462 .

6464.

6465 .

6466 .

6467 .

6715.

6717.

6718.

6719.

6720 .

6802 .

6804.

6805 .

6806 .

7117.

7119.

7120 .

7121 .

7601.

7603.

7604 .

7605 .

7606 .

7673.

7675.

7676 .

7677.

7678 .

7679 .

7680 .

7748 .

7750 .

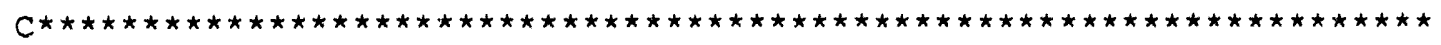

SUBROUTINE REPORT (NRGN, INDOC)

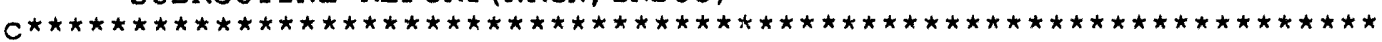

C THIS SUBROUTINE CONTROLS WHICH OUTPUT REPORTS ARE PRINTED

C LARGE OR SMALL REPORT CAN BE PRINTED

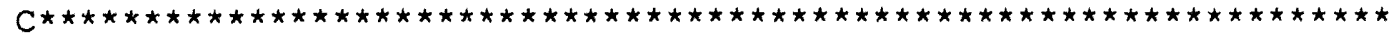

SUBROUTINE TMPSET (IT, NRGN, IC)

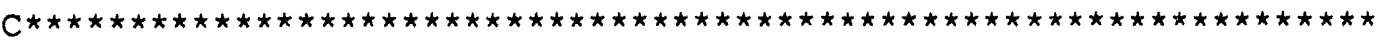

C THIS SUBROUTINE SETS UP TEMPORARY ARRAYS OF REPORT DATA

C FOR THE GIVEN REGION AND TYPE

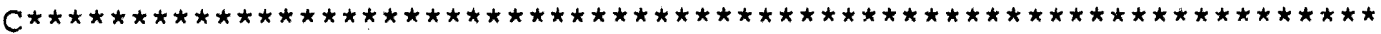

SUBROUTINE ADDUP (NRGN)

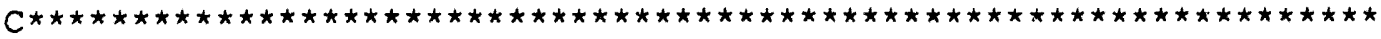

C THIS SUBROUTINE SUMS UP THE REGIONAL RESULTS TO YIELD

C TOTALS ACROSS ORERATING COMPONENT AND OWNERSHIP TYPES

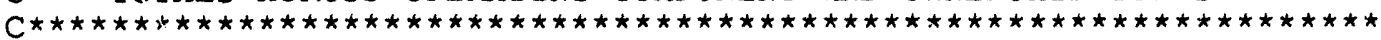

SUBROUTINE REALS (ITYPE)

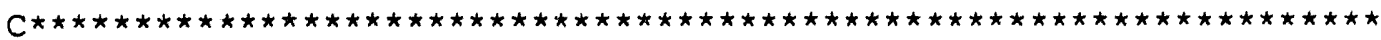

C THIS SUBROUTINE CONVERTS ALL DOLLARS FROM NOMINAI TO REAL

C DOLIARS. THIS IS DONE ONLY WHEN REQUESTED (WHEN IREALS=1)

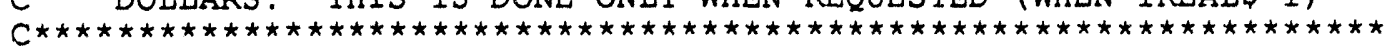

SUBROUTINE REPLAR (ITYPE)

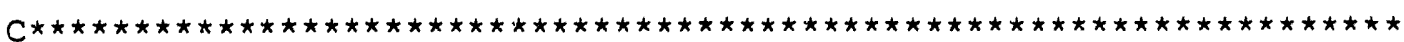
C THIS SUBROUTINE PRINTS THE LARGE REPORT

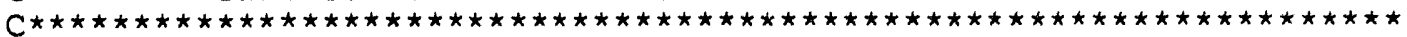

SUBROUTINE REPSML (ITYPE, NRGN, INDOC)

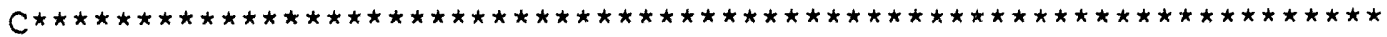
C THIS SUBROUTINE PRINTS THE SMALL REPORT

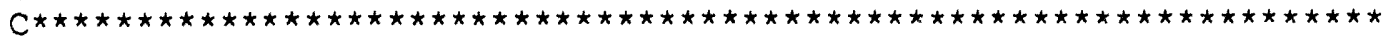

SUBROUTINE ELRDND (IN)

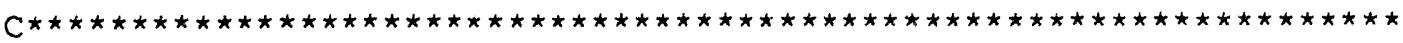

C -ELRDND-

C This subroutine reads in the nuclear decomissioning data.

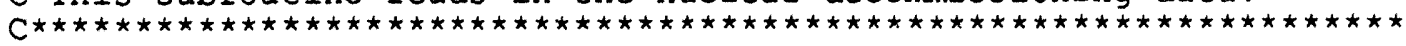

SUBROUTINE ELND (NRGN, ICALI)

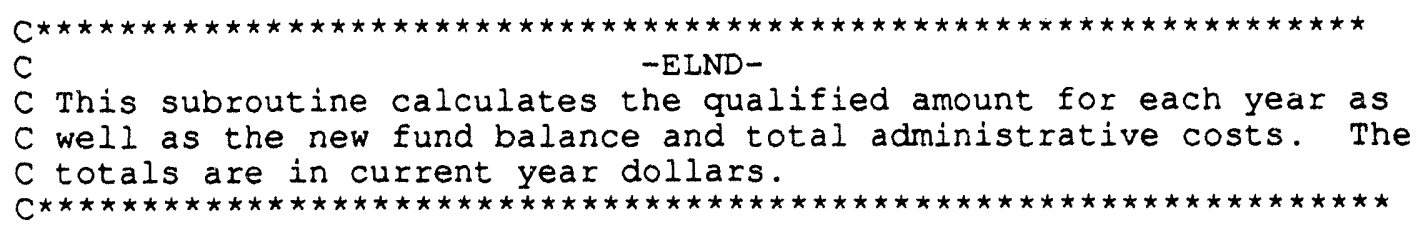

SUBROUT INE ANEWBID (NRGN)

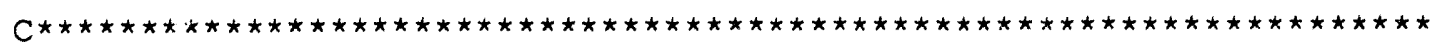

Electricity Finance and Pricing Submodule Documentation - April 1994 
7751. C THIS SUBROUTINE CREATES A NEW BUILD FOR PURPOSES OF RECORDING 7752. C THE COSTS OF CAPITAL ADDITIONS, PHASE-INS, AND SALE7753.

7754 . LEASEBACKS, AND LIFE EXTENSIONS

7795 .

SUBROUTINE ELRDLE(IN)

7797 .

7798 .

7799 .

7800 .

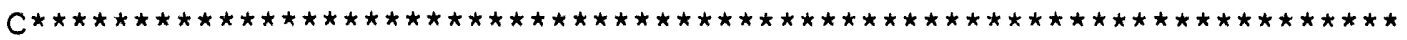
$\mathrm{C}$

-ELRDLE-

C This subroutine reads in the IIFE EXTENSION data.

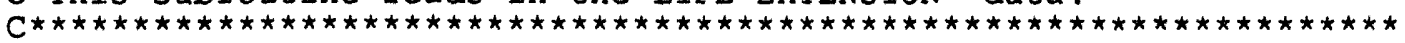




\section{Appendix B Listing of Computations ${ }^{26}$}

The following section shows the calculations used in the EFP. Line numbers are included and may be cross referenced with the previous section listing the subroutines to aid the user in finding particular bits of code for future changes.

COST OF CAPITAL

AA BOND RATE ADJUSTMENT (Please note that this is a temporary fix for the macroeconomir side cases in the Annual Energy Outlook 1994).

2141. C THESE CALCULATIONS SHOULD BE USED ONLY FOR YEARS IN WHICH THE

2142. C COST OF CAPITAL THAT WAS READ IN IS TO BE OVERWRITTEN -

2143. C IST ITERATION ONLY

2144

2145 .

2146 .

IF (CURIYR .GT. 3) THEN

IF (CURITR .EQ. 1) THEN

2151. C APPLY ADJUSTMENT TO UTILITY BOND RATE IN MACRO CASE SINCE SEEDBACK

2152. C FOR CAPITAL INVESTMENT NOT LIKED

2153 .

2154 .

2155 .

UTAART = MC RMPUAANS (CURIYR)

IF (CURIYR.GE. $\overline{8}$ )

2156. $+\quad$ UTAART $=$ MC RMPUAANS (CURIYR) + UAAADJ (MMAC)

NEW LONG TERM (LT) DEBT

2147.

2148 .

2149 .

$\operatorname{ESRTLT}(1)=(\operatorname{UTBRRG}(1, \operatorname{NRGN})+(\operatorname{UTBRRG}(2$, NRGN) *MC_RMPUAANS (CURIYR)) 1100

$\operatorname{ESRTLT}(2)=(\operatorname{BRMCF}(1)+(\operatorname{BRMCF}(2) \star M C$ RMPUAANS $(C U R I Y R))) / 100$

COMMON STOCK

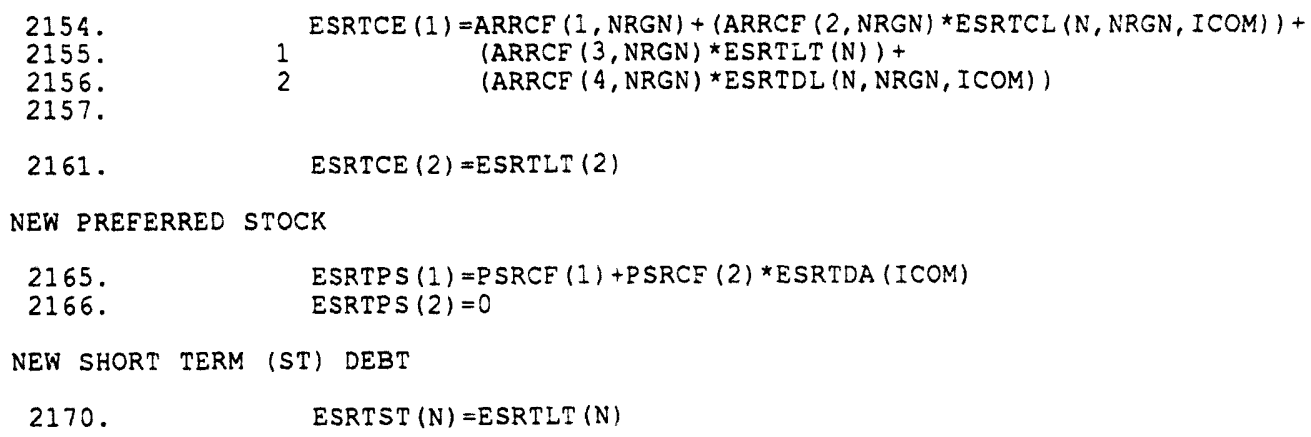

2161 .

NEW PREFERRED STOCK

${ }^{26}$ All listings of code are from CN6005.PRJ.NEMS.FORTRN.UEFP.D1123931 except AA BOND RATE ADJUSTMENT which is from CN6005.PRJ.NEMS.FORTRN.UEFP.D1217931. 
2669.

$\operatorname{TEMPE}=\left(\operatorname{ESPRCE}(\mathrm{N}){ }^{\star} \operatorname{ESRTCE}(\mathrm{N})\right)+(\operatorname{ESPRPS}(\mathrm{N}) \star \operatorname{ESEMPL}(\mathrm{N}))$

PRE-TAX AEUDC RATE

2676.

$\operatorname{ESAFDC}(\mathrm{N})=$ TEMPD + TEMPE

DEBT PORTION

2679.

ESWACD $(N)=$ TEMPD/ESAFDC $(N)$

DIRECI CAPITAL EXPENDITURES

GENERATION

\begin{tabular}{|c|c|c|c|}
\hline $\begin{array}{l}2864 . \\
2865\end{array}$ & 1 & $\operatorname{EBYCWP}(I, N)$ & $\begin{array}{c}=\operatorname{CONPER}{ }^{\star E B P C A P}(I, N) * E B P C S \pi(I) \\
* M M_{-} P G D P(C U R I Y R)\end{array}$ \\
\hline 2945. & & EBYCWP (EBNUM & $1, N)=\operatorname{EBYCWP}($ EBNUM, $N)+$ CAPAD \\
\hline
\end{tabular}

TRANSMISSION

971. C UTEMCP = TRANSMISSION ENERGY-MILE CAPITAL COST

997. $\operatorname{READ}(I N, *) \operatorname{UTEMCP}(I, N)$

1747.

ETEMCP = UTEMCP (CURIYR, NRGN)

DISTRIBUTION

$\begin{array}{ll}\text { 2317. } & \text { DCP }=\text { (DSTSLP*EQTLSL (1)) + DSTCON } \\ 2318 . & \text { DCP }=\text { DCP IESTSHR (1) }\end{array}$

BOOKED AFUDC

CONSTRUCTION WORK IN PROGRESS (CWIP) IN RATEBASE

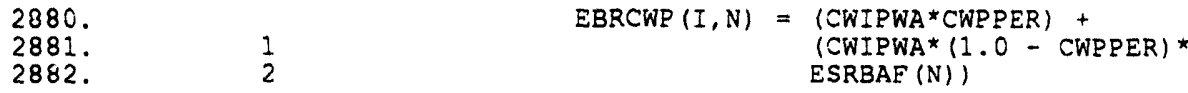

2881 .

2882 .

BOOKED AFUDC

(PLANT NOT ENTERING SERVICE THIS YEAR)

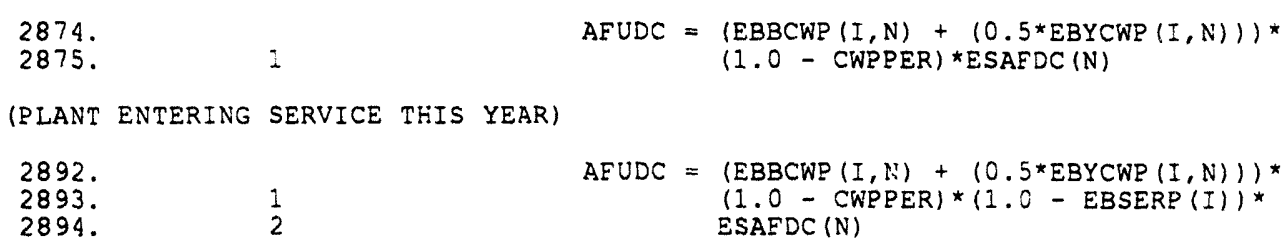

(PLANT ENTERING SERVICE THIS YEAR)

2892.

2893.

2894 .

$\frac{1}{2}$

$\operatorname{AFUDC}=(\operatorname{EBBCWP}(I, M)+(0.5 * \operatorname{EBYCWP}(I, N))) *$ $(1.0$ - CWPPER $) *(1.0$ - EBSERP (I) $) *$ ESAFDC (N)

AFUDC OFFSET

2911.

$\operatorname{EROFFS}(N)=\left(\operatorname{AFUDC}{ }^{\star} \operatorname{ESRBAF}(\mathrm{N})\right)+\operatorname{EROFFS}(\mathrm{N})$

BOOKED CWIP

2878 .

$\operatorname{EBBCWP}(I, N)=$ CWIPWA + AEUDC

TAX BASIS (TAX REFORM ACT OF 1986 - TRA - ONLY)

AVOIDED INTEREST

(RLANT NOT ENTERING SERVICE THIS YEAR)
2876 .
AVDINT $=($ ELASVL $+(0.5 * \operatorname{EBYCWP}(I, N))) *$

(PLANT ENTERING SERVICE THIS YEAR) 


\section{2}

2896.

AVDINT $=($ ELASVL $+(0.5 * \operatorname{EBYCWP}(I, N))) *$ $\operatorname{ESRTLT}(N) *(1.0-\operatorname{EBSERP}(I))$

TAX BASIS

2868 .

$\operatorname{EBASVL}(I, N)=\operatorname{EBASVL}(I, N)+\operatorname{EBYCWP}(I, N)$

ADD AVOIDED INTEREST

2915.

$\operatorname{EBASVL}(I, N)=\operatorname{EBASVL}(I, N)+\operatorname{AVDINT}$

ADD POST OPERATIONAL CAPITAL EXPENDITURES

2961.

EBASVL $(E B N U M, N)=\operatorname{EBASVL}(E B N U M, N)+$ CAPAD

ADD LIFE EXTENSION

2970.

EBASVL (EBNUM, N) = EBASVL (EBNUM, N) + CAPLE (N, NRGN, CURIYR)

LOWER BY HALF OF DEFERRED INCOME TAX CREDIT (DITC) IF ASSETS ARE POST TEFRA

3432 .

3433.

$\operatorname{EBASVL}(I, N)=\operatorname{EBASVL}(I, N)-$

$0.5^{*} \operatorname{EBDITC}(I, \mathrm{~N})$

ADJUST FOR SALES/LEASEBACK

4428 .

$\operatorname{EBASVL}($ EBNUM, I $)=\operatorname{EBASVI}(\mathrm{EBNUM}, I)-\mathrm{ASVI}$

AFUDC ACCOUNTS

DEBT PORTION OF AFUDC

2910.

$\operatorname{ERFDCD}(N)=$ DEBTAF + ERFDCD $(N)$

EQUITY PORTION OF AFUDC

2908.

$\operatorname{ERFDCE}(N)=(A F U D C * W A C E)+\operatorname{ERFDCE}(N)$

CAPITALIZED INTEREST DURING CONSTRUCTION

(CAPITALIZE)

2916.

$\operatorname{ERCIDC}(N)=\operatorname{ERCIDC}(N)+\operatorname{AVDINT}$

(DO NOT CAPITALIZE)

2920.

$\operatorname{ERCIDC}(\mathrm{N})=\operatorname{ERCIDC}(\mathrm{N})+$ DEBTAE

BOOK DEPRECIATION

3065 .

3066 .

1

3084

$B D E=(E O B K V L(I Y R, J, N)-E O A B D E(I Y R, J, N))$

/ (NRETIR - CURIYR)

$\operatorname{ERBDEI}(\mathrm{N})=\mathrm{BDE}+\operatorname{ERBDE} I(\mathrm{~N})$

3084 .

$\operatorname{BDE}=(\operatorname{EBBKVL}(I, N) / \operatorname{ESBKLF}(\mathrm{J}, \mathrm{N})) \star \operatorname{EBSERP}(I)$

3095 .

$B D E=\operatorname{EBBKVL}(I, N)-\operatorname{EBABDE}(I, N)$

3100 .

3101 .

3102 .

$\frac{1}{2}$

$B D E=(\operatorname{EBBKVL}(I, N)-\operatorname{EBABDE}(I, N))$

( $\operatorname{ESBKLF}(\mathrm{J}, \mathrm{N})$ - (CURIYR - EBSYR(I) +

3111 . $\operatorname{EBSERP}(I)-1))$

$\operatorname{ERBDE} 2(\mathrm{~N})=\mathrm{BDE}+\operatorname{ERBDE} 2(\mathrm{~N})$

3117 .

$\operatorname{ERBDE}(\mathrm{N})=\operatorname{ERBDE} 2(\mathrm{~N})+\operatorname{ERBDE} 1(\mathrm{~N})$

STRAIGHT LINE TAX DEPRECIATION

EXISTING ASSETS

3063 .

3064 .

1

$\operatorname{ERTDW} 1(N)=\operatorname{EODEPR}\left(\mathrm{J}, \mathrm{N}:{ }^{\star} \operatorname{EOASVL}(I Y R, J, N)+\right.$ ERTDW1 (N)

Electricity Finance and Pricing Submodule Documentation - April 1994 
NEW ASSETS

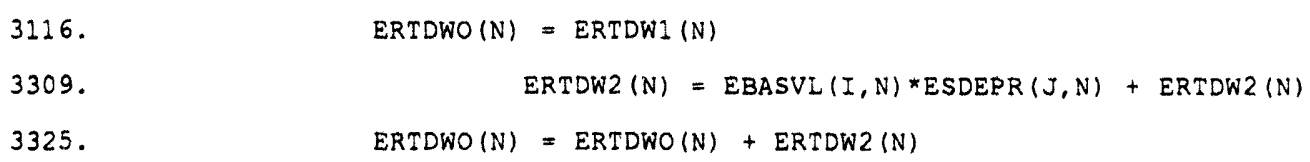

ACCELERATED TAX DEPRECIATION

EXISTING ASSETS

(ERTA MODIFIED BY TEFRA IF VINTAGE YEAR IS 1981 TO 1984)

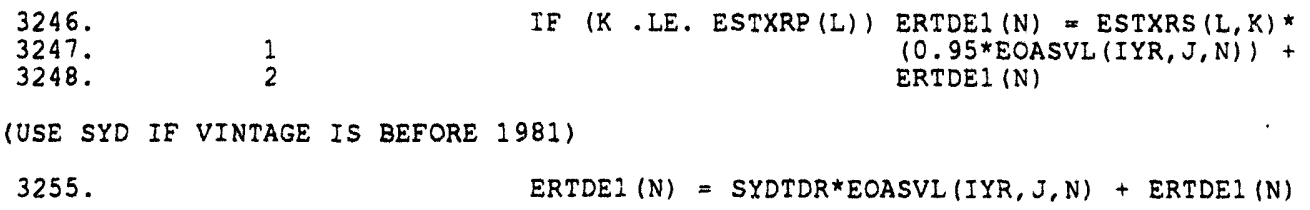

3255 .

ERTDEI $(N)=$ SYDTDR*EOASVL (IYR, J,N) + ERTDEI (N)

NEW ASSETS

(USE SYD)

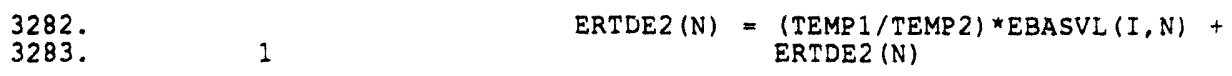

(USE ERTA MODIFIED BY TEFRA)

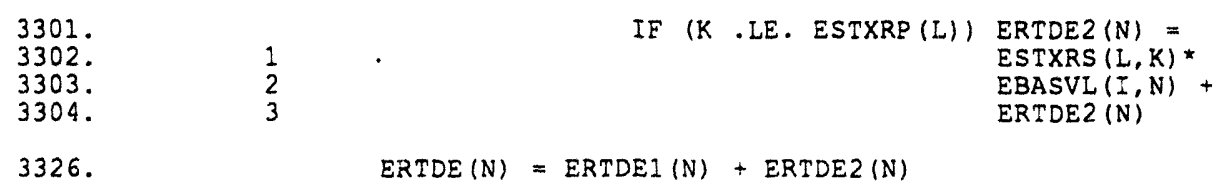

RATEMAKING DEPRECIATION

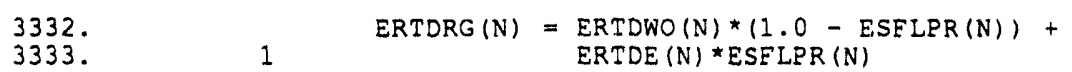

TAX SAVINGS DUE TO ACCEL. DEPREC. FLOWED THROUGH

(EXISTING ASSETS WITH ADJUSTMENT IF CUM. DEFERRALS ARE GREATER THAN O)

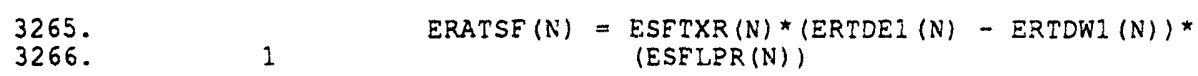

(NEW ASSETS)

$$
\begin{array}{lll}
\text { 3327. } & \operatorname{ERATSF}(N)= & \operatorname{ESFTXR}(N) *(\operatorname{ERTDE} 2(N)-\operatorname{ERTDW} 2(N))) * \\
3328 . & 1 & \operatorname{ESTPR}(N)+\operatorname{ERATSE}(N)
\end{array}
$$

DEFERRED TAX SAVINGS DUE TO ACCELERATED DEPRECIATION

(OLD ASSETS)

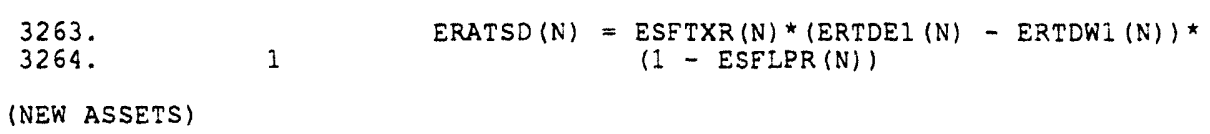


3329. $\operatorname{ERATSD}(N)=(\operatorname{ESFTXR}(N) *(\operatorname{ERTDE} 2(N)-\operatorname{ERTDW} 2(N))) *$
3330 .
1
$(1-\operatorname{ESELPR}(N))+\operatorname{ERATSD}(N)$

PROVISION FOR DEFERRED TAXES DUE TO ACCEL. DEPREC. AND DEBT AFUDC

(TAX SAVINGS DUE TO ACCELERATED DEPRECIATION)

3331 .

$\operatorname{ERPRDE}(N)=\operatorname{ERPDFL}(N)+\operatorname{ERATSD}(N)$

(TAX SAVINGS DUE TO THE DEBT PORTION OE AFUDC)

3524 .

$\operatorname{ERPRDF}(N)=\operatorname{ERPRDF}(\mathrm{N})+\operatorname{ERXFDC}(\mathrm{N})-\operatorname{ERAFDC}(\mathrm{N})$

(DELETE DEEERRED AMOUNT FLOWED THROUGH THIS YEAR)

3713. $\operatorname{ERPRDF}(N)=\operatorname{ERPRDF}(N)-\operatorname{EREDTE}(N)$

ANNUAL INVESTMENT TAX CREDIT (ITC)

ANNUAL ITC FIOWED THROUGH

3426 .

$\operatorname{ERFITC}(N)=\operatorname{GITC} * \operatorname{ESFLPR}(N)+\operatorname{ERFITC}(N)$

ANNUAL ADDITION TO DEFERRED ITC

3429 .

$X I T C D=X I T C D+X I T C D P$

ANNUAL ITC AHORTIZATION

(ITC FROM NEW ASSETS)

3428 .

$\operatorname{EBDITC}(I, N)=\operatorname{EBDITC}(I, N)+\operatorname{XITCDP}$

AMORTIZATION PER YEAR OF DEFERRED ITC

(DEFERRED ITC FROM EXISTING ASSETS)
3409 .
3410 .
$\frac{1}{2}$
IF (CURIYR . LT. NRETIR) ERAITC(N) =
3411 . EOAITC (IYR, J,N) + ERAITC (N)
(DEFERRED ITC FROM NEW ASSETS)
3428 .$$
\operatorname{EBDITC}(I, N)=\operatorname{EBDITC}(I, N)+\operatorname{XITCDP}
$$

AMORT'D. AMT. (3434: LOWERED TAX BASIS FOR POST TEFRA AND 3441:OTHERS)

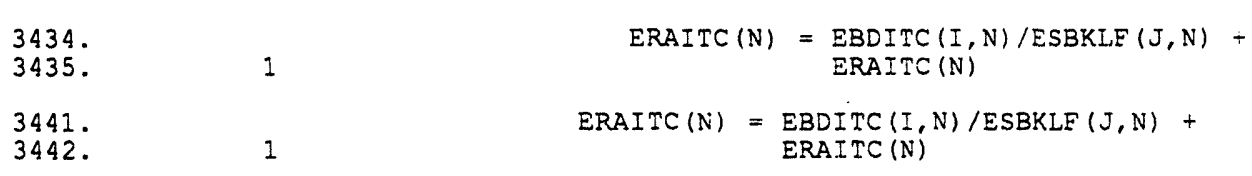

TOTAL ACCRUED EXCESS DEFERRED TAXES (EDT)

EXCESS DEPRECIATION AS A FRACTION OF THE TAX BASIS

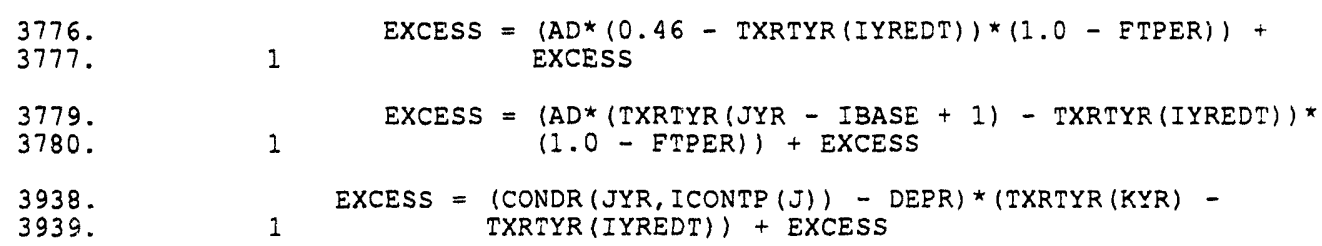

AMOUNT OF EXCESS DEFERRED TAXES FLOWED THROUGH THIS YEAR

4002. UREDTE (NRGN, IYREDT) = UREDTE (NRGN, IYREDT) + EXCESS

4007. UREDTE (NRGN, JYR) = UREDTE (NRGN, JYR) + YREX 


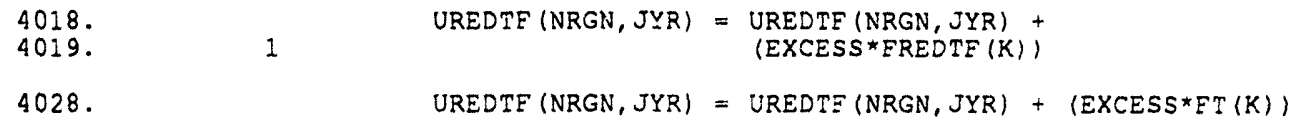

4156 .

4157.

4158 .

4159.

4160 .

4161 .

4162 .

4163.

4164 .

4165 .

ANNUAL DEFERRED COST OF PHASE-IN

(DEFERRED AMOUNT THIS YEAR)

4166.

4167 .

1

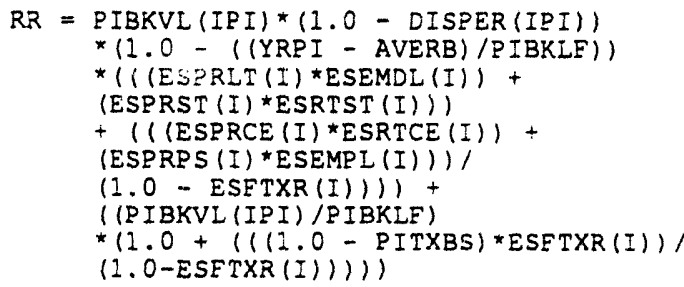

RECOVERY OE PAST DEFERRED COSTS

$43: 7$.

DEFCST $=$ DEFCST - (RIRCS (IYRPI,IPI $) *$

4318.

1 PIDEE (IPI;)

CUMULATIVE DEFERRED COST

4184 .

$\operatorname{EPIDEF}(I)=\operatorname{EPIDEF}(I)+\operatorname{PIDEF}(I P I)$

NET VALUE OF DISALLOWED PLANT
4190.
4191.
$\frac{1}{2}$
$\operatorname{EDISNT}(I)=\operatorname{EDISNT}(I)+(($ PIBKVLIIPI)* (1.0 - (YRPI/E ZBKLE)))* DISPER (IPI))

SALE/LEASEBACK REVENUE

BOOK VALUE OF PLANT SOLD

774. SLBKVL (NSL) = SLPROC (NSL) - BKGAIN

NET GAIN ON BOOK VALUE

775. SLGAIN (NSL) = BKGAIN - SLTAXS (NSL)

ASSET VALUE OF SALES/LEASEBACK PLAN

4424 .

ASVL = SLPROC (ISL) - SLTAXS (ISL)/ESETXR (I)

(IE FEDERAL INCOME TAXES EQUAL 0 )

4426 .

ASVL $=$ SLBKVL (ISL)

PROCEEDS NET OF TAXES

4429.

4430 .

$\operatorname{ESLPRC~(I)~=~ESLPRC~(I)~+~SLPROC~(ISL)~-~}$ SETAXS (ISI)

AMORTIZATION OF GAIN 
4434

4435 .

NET DEFERRED GAIN

4436 .

LEASE PAYMENT

4433 .
$A M O R=S I G A I N(I S L) / S L T E R M(I S L)$

ESLAGN $(I)=E S L A G N(I)+A M O R$

$\operatorname{ESLNDG}(I)=\operatorname{ESLNDG}(I)+\operatorname{SLGAIN}(I S L)-A M O R * Y R S I$

$\operatorname{ESLLP}(I)=\operatorname{ESLLP}(I)+\operatorname{SLLP}(I S L)$

TOTAL FUEL COSTS IN NOMINAL DOLLARS

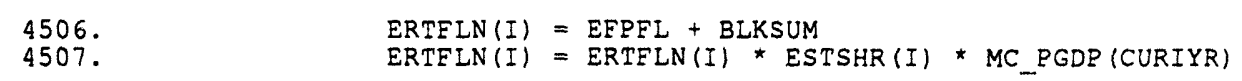

OPERATION AND MAINTENANCE (O\&M) EXPENSES

GENERATION O\&M

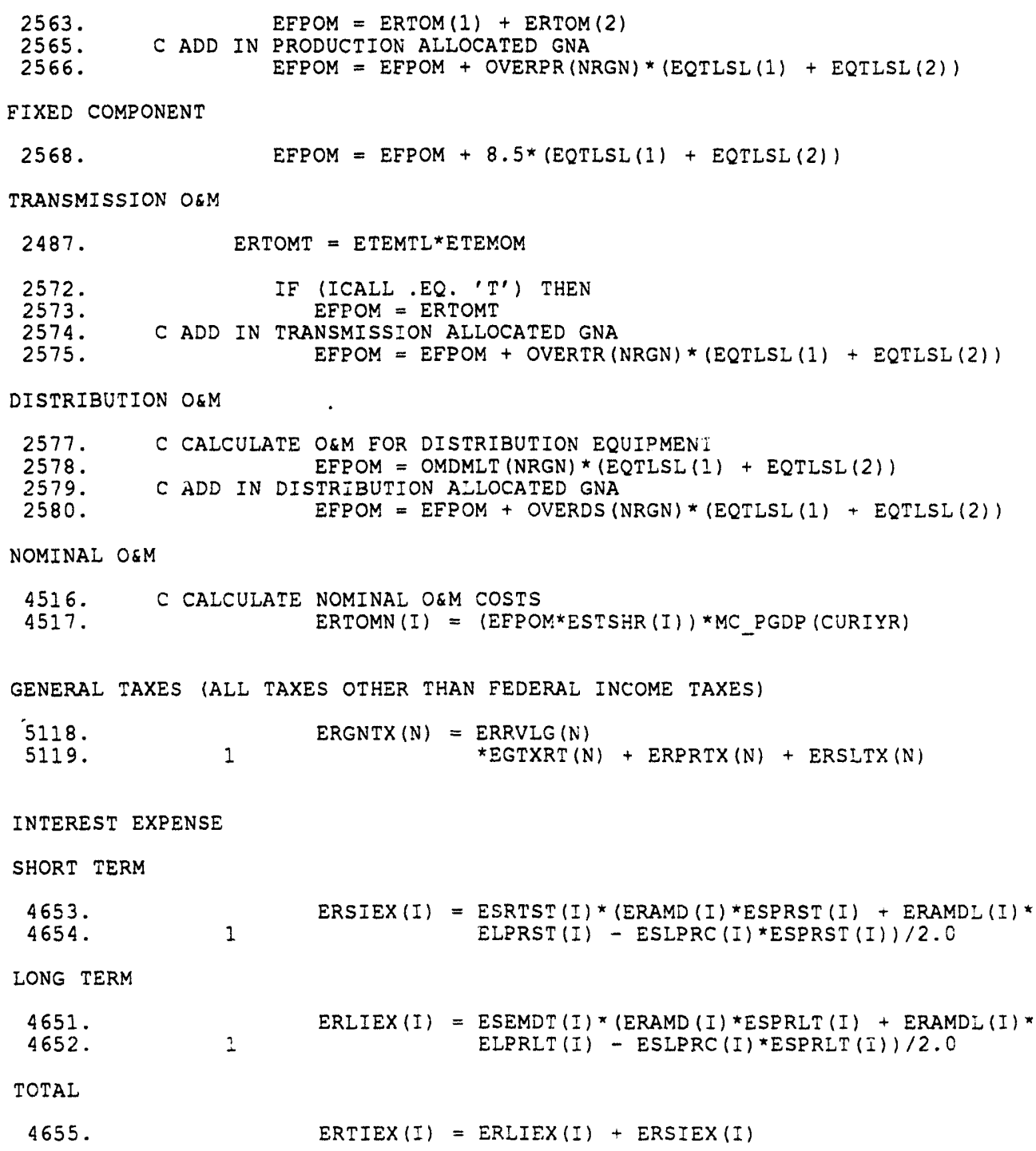


ASSETS MINUS DEFERRALS (AMOUNT TO BE EINANCED)

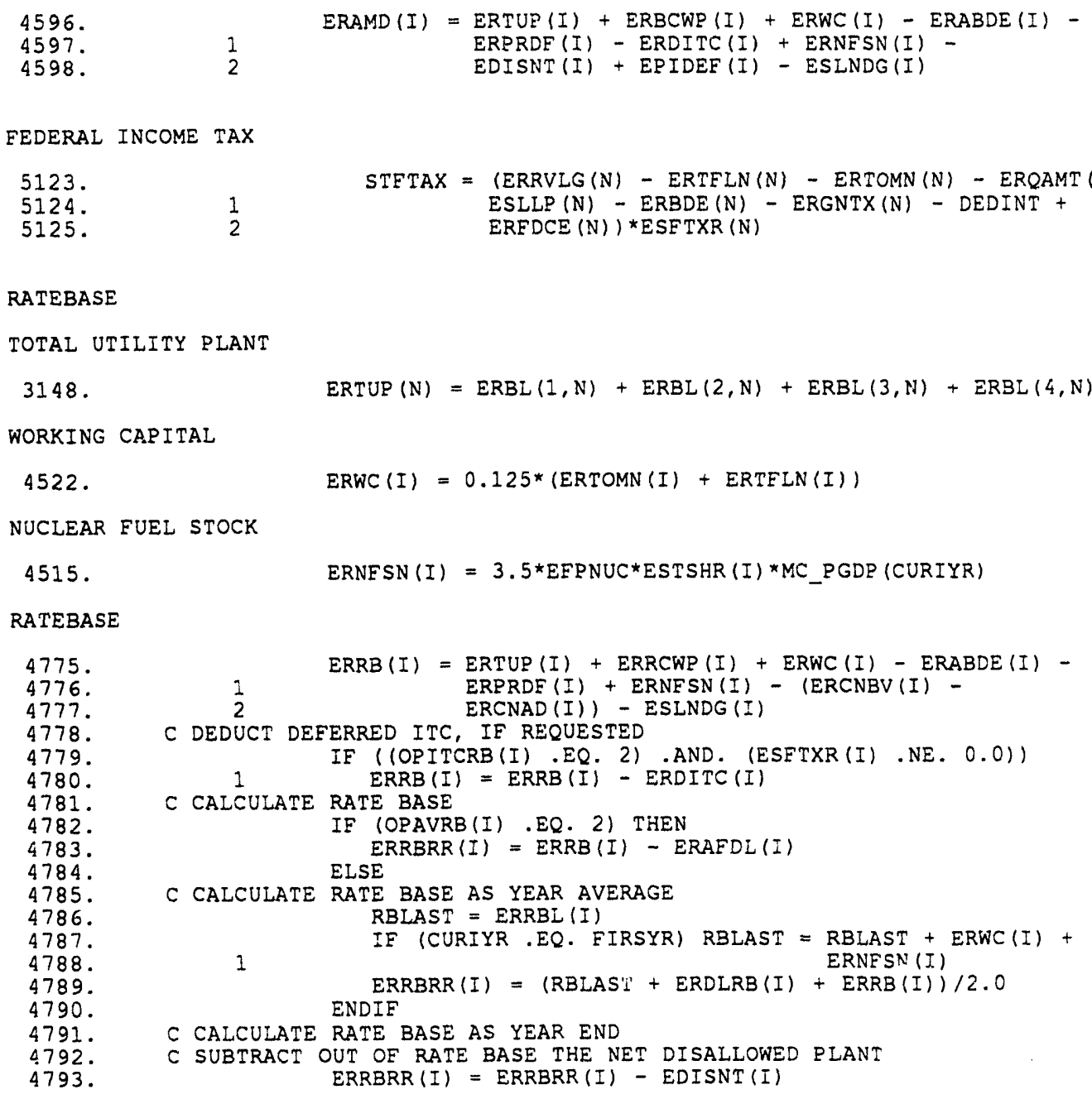

RATE OF RETURN

LONG TERM (LT) DEBT

(DEBT RETIREMENTS)

4616.

$\operatorname{RETIRE}=\operatorname{ESPRLT}(I) \star E R B D E(I)$

(LT DEBT OUTSTANDING)

4617.

4618 .

4619 .

4620 .

4621 .

$\operatorname{EROB}(I)=\operatorname{EROBL}(I)-R E T I R E$

IE (EROB (I) . LE. 0.0$)$ THEN

RETIRE = RETIRE + EROB (I)

$\operatorname{EROB}(I)=0.0$

ENDIE

(NEW LT DEBT)

4602 .

$\operatorname{ERBOND}(I)=\operatorname{ERAMD}(I) \star \operatorname{ESPRLT}(I)$

(EMBEDDED COST OF IT DEBT)

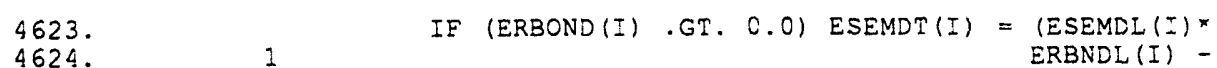




\begin{tabular}{|c|c|c|}
\hline $\begin{array}{l}4625 . \\
4626 . \\
4627 . \\
4628 . \\
4629 . \\
4630 \\
4631\end{array}$ & $\begin{array}{l}2 \\
3 \\
4 \\
5 \\
6 \\
7 \\
8\end{array}$ & 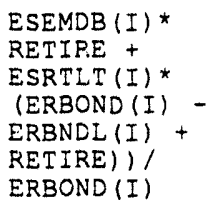 \\
\hline
\end{tabular}

PREFERRED STOCK

(PREFERRED STOCK RETIREMENTS)

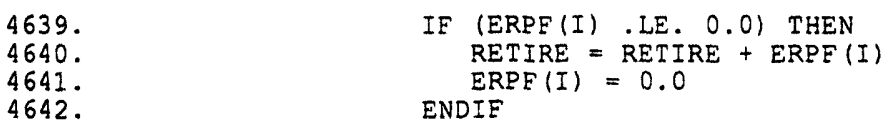

(PREFERRED STOCK OUTSTANDING)

4638 .

$\operatorname{ERPF}(I)=\operatorname{ERPFL}(I)-\operatorname{RETIRE}$

(NEW PREFERRED STOCK)

4636. $\operatorname{ERPREF}(I)=\operatorname{ERAMD}(I) \star \operatorname{ESPRPS}(I)$

(EMBEDDED COST OF PREFERRED STOCK)

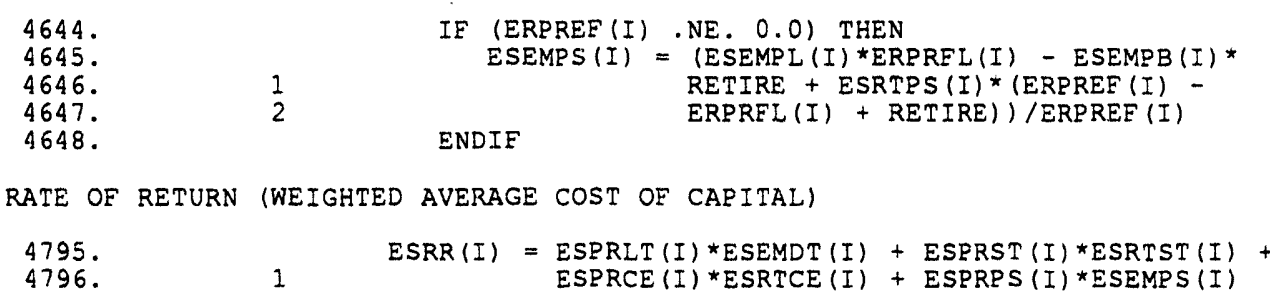

REVENUE REQUIREMENT

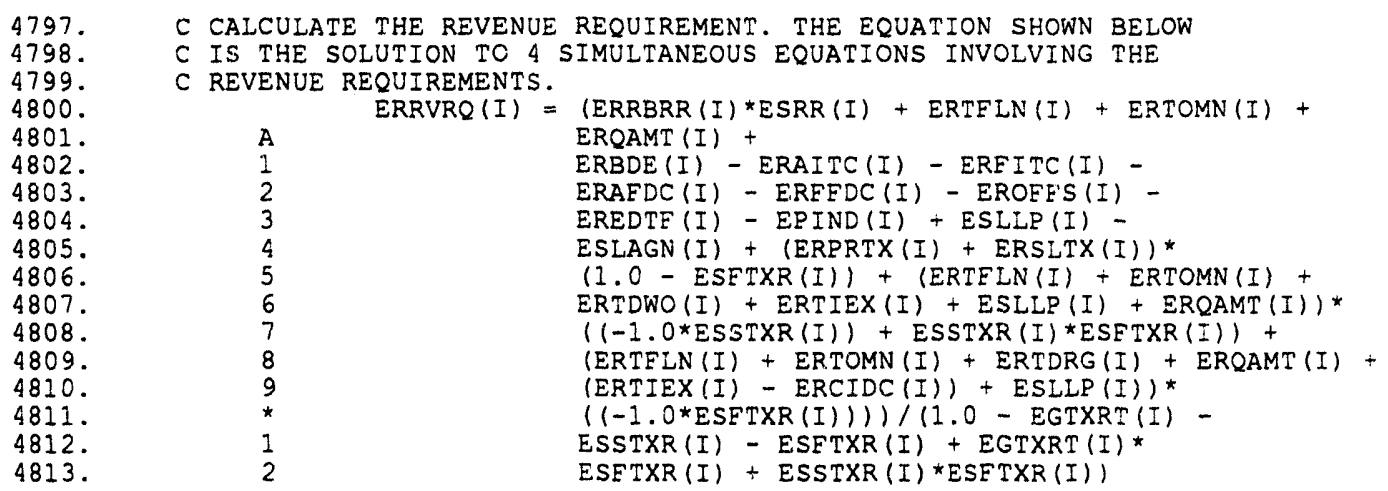

ELECTRIC REVENUES

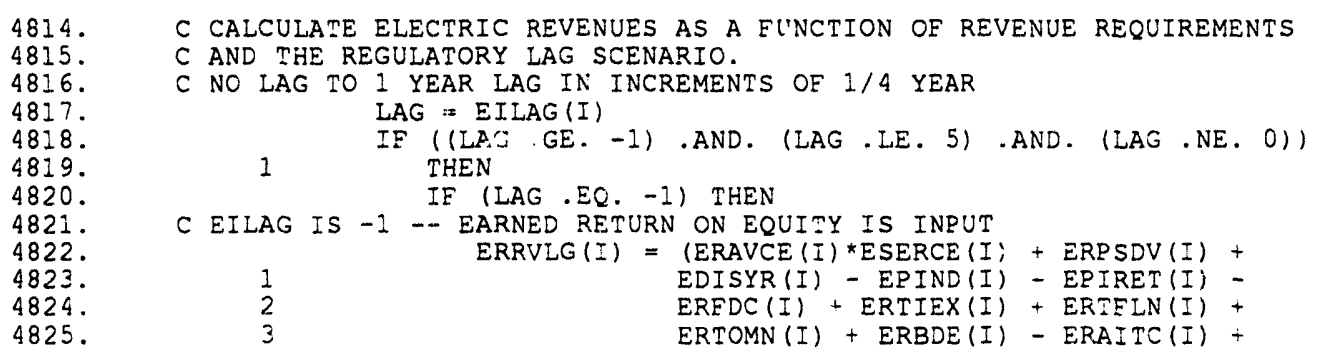




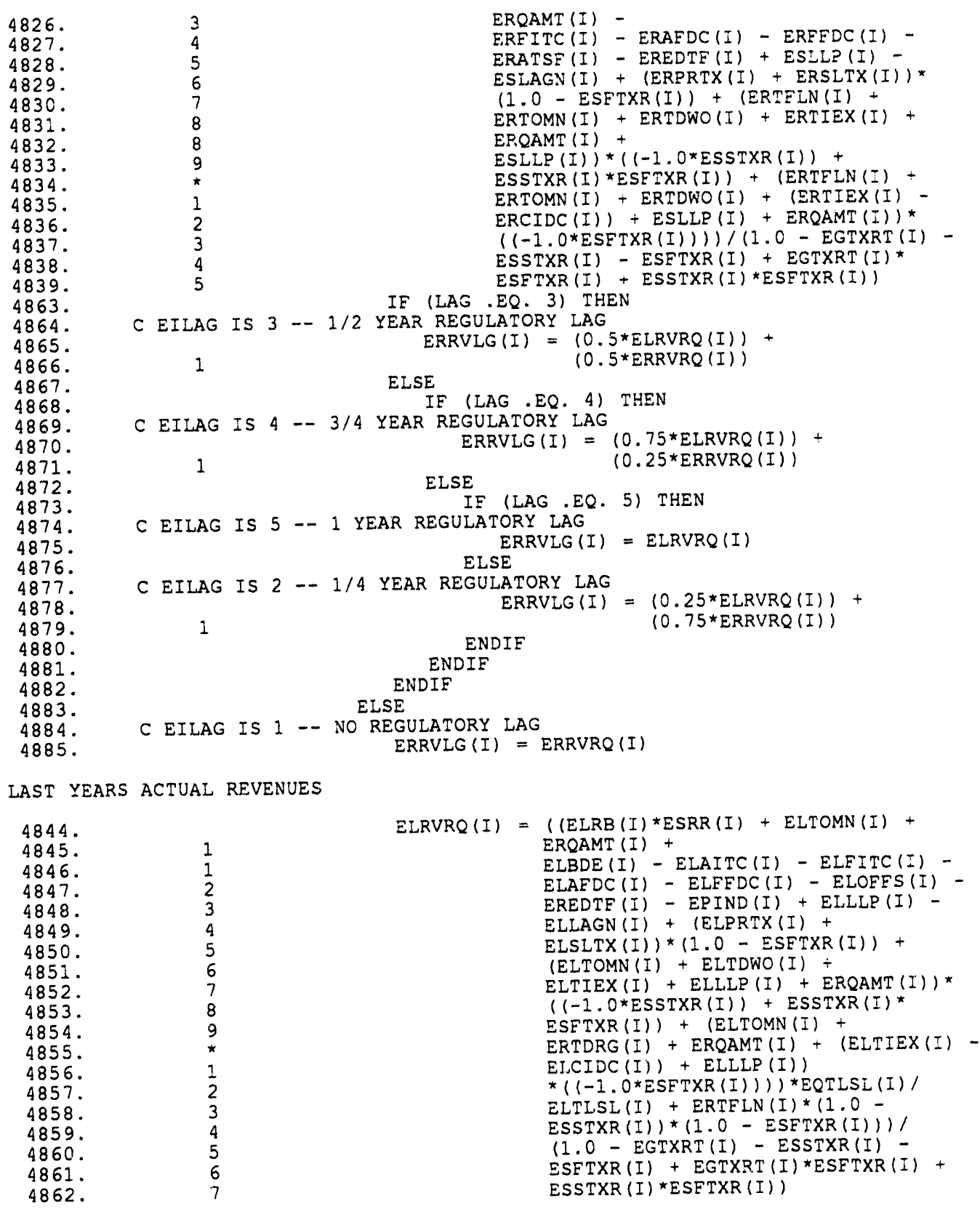

ELECTRICITY PRICES

PROBABILITY OF CONTRIBUTION TO PEAK

1639.

PCP (ICLS) = SECANNPEAAVPCP (NRGN, ICLS)

1642 .

$\operatorname{DEMFAC}(\sigma$, ICLS) = SECANNPEAAVPCP (NRGN, ICLS) $/$ TOTAL

NON COINCIDENT PEAK

1648 .

$\mathrm{NCP}($ ICLS $)=$ SECANNUALPEAK $(N R G N$, ICLS, 2)

2651 .

$\operatorname{DEMFAC}(7$, ICLS $)=\operatorname{SECANNUALPEAK}(N R G N$, ICLS, 2)/TOTAL 
ANNUAL AND EXCESS DEMAND WITH PROBABILITY OF CONTRIBUTION TO PEAK
1658 .
$\operatorname{DEMFAC}(9$, ICLS) $=$ SYSTEMLF (NRGN) *DEMFAC $(1, \operatorname{ICLS})+$
1659 .
1
$(1.0$ - SYSTEMLF (NRGN)) DEMFAC $(6$, ICLS)

COST ALLOCATION FACTORS

$\begin{array}{lcc}5434 . & \text { COSTFC (ICOST, ICLS, ISECT) }= & \text { (DEMFAC (ITECH, ICLS) } \\ 5435^{\circ} & 1 & \text { (TECFAC (ITECH, ICOST, ISECT)/100.0) } \\ 5436 . & 2 & + \text { COSTEC (ICOST, ICLS, ISECT) }\end{array}$

CUSTOMER CLASS REVENUE ALLOCATION

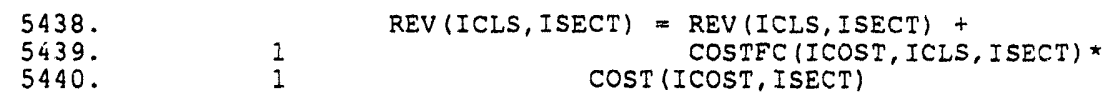

CUSTOMER CLASS PRICES

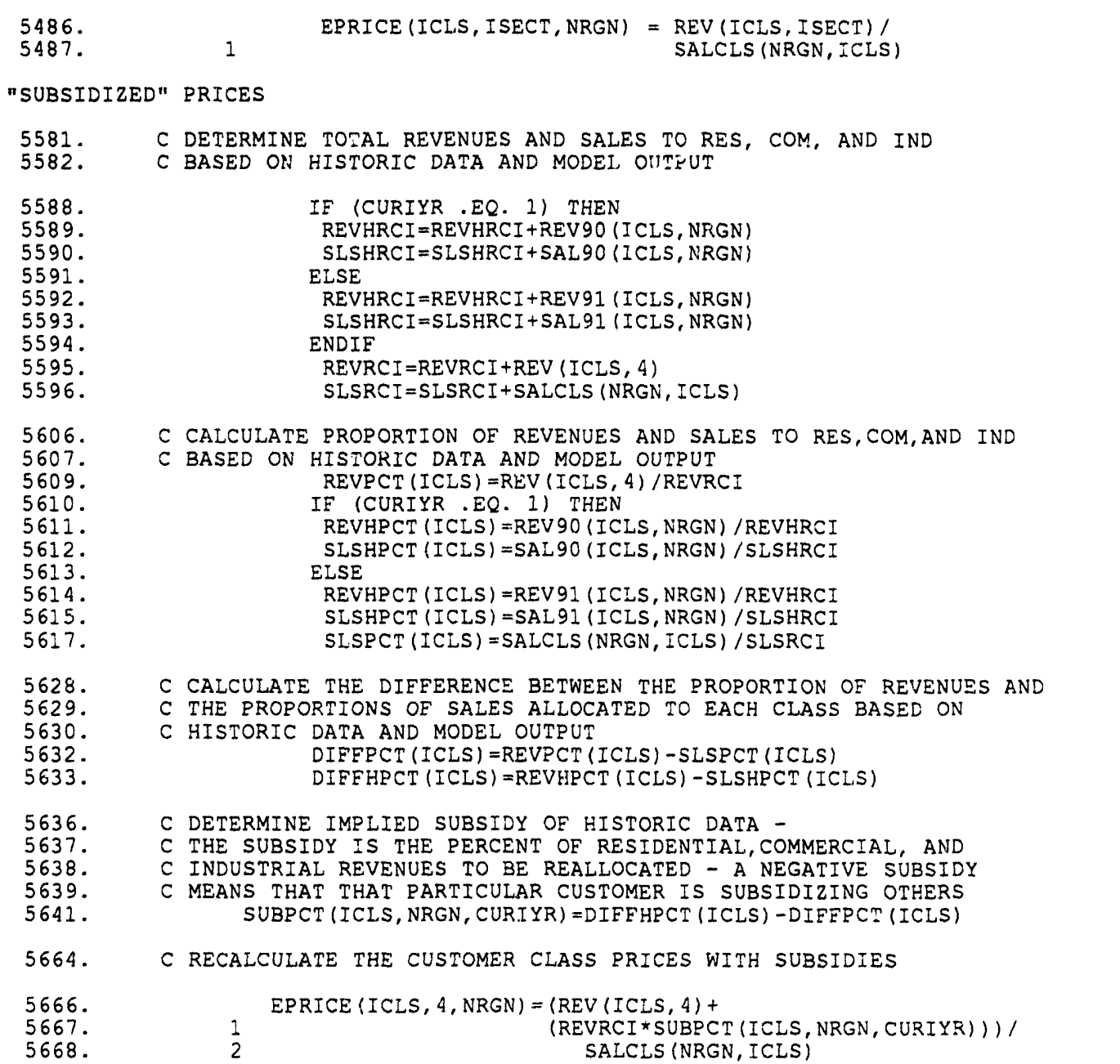




\section{Appendix C \\ Indices and Input/Output Variables}

Following are the abbreviations used in the tables:

Units:

87 \$/kw 1987 dollars per kilowatt

$8710^{\wedge} 6 \$$ million 1987 dollars

KWH kilowatthours

MM \$ thousands of dollars

MM \$/EM thousand dollars per energy mile

MW megawatts

N/A not applicable or not available

$\$ / \mathrm{KW} \quad$ dollars per kilowatt

Submodules, Models:

MACRO Macroeconomic Activity Module

MAIN Main calling routine of the National Energy Modeling System

UDAT Common Utility Data File

UECP Electricity Capacity Expansion submodule

UEFD Electricity Fuel Dispatch submodule

ULDSM Load and Demand Side Management submodule

Input File Names:
EFPALL CN6005.PRJ.EFPALL.scenario.datekey
EFPCNTL CN6005.PRJ.EFPCNTL.scenario.datekey
EFPTAX CN6005.PRJ.EFPTAX.scenario.datekey
ETRANS CN6005.PRJ.ETRANS.scenario.datekey
FINREG CN6005.PRJ.FINREG.scenario.datekey
PHASEIN CN6005.PRJ.PHASEIN.scenario.datekey
SALELB CN6005.PRJ.UEFP.SALELB.scenario.datekey

Sources for Table 4:

$\begin{array}{ll}\text { EIA } & \text { Assumptions made by analysts at the Energy Information } \\ \text { EIA412 } & \text { Administration (EIA). }\end{array}$ 
Administration Form 7

ERTA Economic Recovery Tax Act of 1981

FORM 1 Federal Energy Regulatory Commission (FERC) Form 1

RRA Regulatory Focus, Regulatory Research Associates, Inc., Various Issues

S\&PIS Standard and Poors Industry Surveys, Utilties-Electric, Current Analysis, May 6, 1993, Page U5.

TRA Tax Reform Act of 1986

References under "Block" (Table 2), "Common Block" (Table 4), or "Output To" (Table 5) are members of the partitioned data set CN6005.PRJ.NEMS.COMMON.PDS.datekey.

\begin{tabular}{|c|c|c|}
\hline 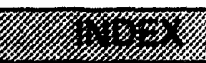 & 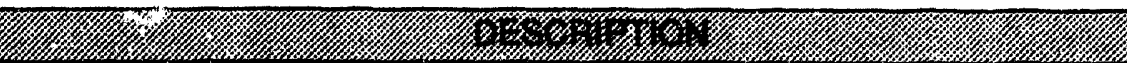 & 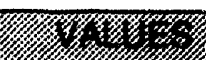 \\
\hline EBNUM & NUMBER OF BUILDS & UP TO 300 \\
\hline EIPROD & NUMBER OF EFP PRODUCTION PLANT TYPES & $\overline{12}$ \\
\hline EOVYRS & NUMBEA OF VINTAGE YEARS & 34 \\
\hline MNUMCR & NUMBER OF CENSUS REGIONS (INCLUDES TOTAL) & 8 \\
\hline MNUMNR & NUMBER OF NERC REGIONS (INCLUDES TOTAL) & 13 \\
\hline NCLASS & NUMBER OF CUSTOMER CLASSES & 4 \\
\hline NCOMP & NUMBER OF OPERATING COMPONENTS & 3 \\
\hline NCOST & NUMBER OF COST CATEGORIES & 4 \\
\hline NERTA & NUMBER OF ERTA DEPRECIATION SCHEDULES & 3 \\
\hline NOCAP & NUMBER OF PLANT TYPE REPORTS & UP TO 16 \\
\hline NOPREG & NUMBER OF PRINT REGIONS & UP TO 44 \\
\hline NOWN & NUMBER OF OWNERSHIP CATEGORIES ( 1 =PRIVATE $2=$ =PUBLIC) & 2 \\
\hline NPI & NUMBER OF PHASE-IN PLANS & UP TO 125 \\
\hline NPTYP & NUMBER OF EFP PLANT TYPES & 16 \\
\hline NSCHED & NUMBER OF TRA DEPRECIATION SCHEDULES & 2 \\
\hline NSL & NUMBER OF SALE/LEASEBACK TRANSACTIONS & UP TO 30 \\
\hline NTECH & NUMBER OF ALLOCATION TECHNIQUES & 9 \\
\hline NUMCAP & \# OF PLANT TYPES IN EACH PLANT TYPE REPORT & UP TO 16 \\
\hline NYRCON & NUMBER OF YEARS IN TRA DEPRECIATION SCHEDULE & 50 \\
\hline NYRCP & NUMBER OF YEARS IN CONSTRUCTION PROFILE & 15 \\
\hline NYREDT & NUMBER OF YEARS TO FLOW BACK EXCESS DEFERRED TAXES & UP TO 20 \\
\hline NYRERT & NUMBER OF YEARS IN ERTA DEPRECIATION SCHEDULE & 15 \\
\hline NYRPI & NUMBER OF YEARS IN PHASE-IN PLANS & UP TO 20 \\
\hline UNYEAR & NUMBER OF YEARS FOR MODEL TO SOLVE & 21 \\
\hline
\end{tabular}




\begin{tabular}{|c|c|c|c|c|c|}
\hline 11.1. & -1 & M & 14 & (1) & - \\
\hline EBPCAP & CAPACITY ASSOCIATED WITH EACH BUILD & EBNUM,NOWN & MW & UECP & EFPBLD \\
\hline EBPCST & $\begin{array}{l}\text { CAPITAL COST ASSOCIATED WITH EACH } \\
\text { BUILD }\end{array}$ & EBNUM & $87 \$ / K W$ & UECP & EFPBLD \\
\hline EBPTYP & PLANT TYPE FOR EACH BUILD & EBNUM & N/A & UECP & EFPBLD \\
\hline EBSERP & $\begin{array}{l}\text { \% OF YEAR PLANT IS IN SERVICE DURING } \\
\text { THE FIRST YEAR }\end{array}$ & EBNUM & FRACTION & UECP & EFPBLD \\
\hline EBSYR & YEAR WHICH PLANT COMES ON LINE & EBNUM & YEAR & UECP & EFPBLD \\
\hline EOMW & VINTAGE CAPACITY EXISTIING IN BASE YEAR & $\begin{array}{l}\text { EOVYRS,NPROD, } \\
\text { NOWN,MNUMNR }\end{array}$ & MW & UDAT & EFPIN \\
\hline ERFFL(19) & NUCLEAR FUEL COSTS IN REAL DOLLARS & NONE & $8710^{\wedge} 6 \$$ & UEFD & DISPOUT \\
\hline ERTFL & TOTAL FUEL COSTS IN REAL DOLLARS & NOWN & $8710^{\wedge} 6 \$$ & UEFD & DISPOUT \\
\hline ERTOM & $\begin{array}{l}\text { TOTAL PRODUCTION OPERATION \& } \\
\text { MAINTENANCE COSTS IN REAL DOLLARS }\end{array}$ & NOWN & $8710^{\wedge} 6 \$$ & UEFD & DISPOUT \\
\hline ETDMDE & REVENUES FROM ECONOMY POWER SALES & NONE & $8710^{\wedge} 6 \$$ & UEFD & DISPOUT \\
\hline ETDMDF & REVENUES FROM FIRM POWER SALES & NONE & $8710^{\wedge} 6 \$$ & UECP & DISPOUT \\
\hline ETDMME & ECONOMY POWER SALES & NONE & KWH & UEFD & DISPOUT \\
\hline ETDMMF & FIRM POWER SALES & NONE & $\mathrm{KWH}$ & UECP & DISPOUT \\
\hline ETEXPD & $\begin{array}{l}\text { EXPORTED POWER (CANADAMEXICO) } \\
\text { REVENUES }\end{array}$ & NONE & $8710^{\wedge} 6 \$$ & UEFD & DISPOUT \\
\hline ETEXPE & $\begin{array}{l}\text { EXPORTED POWER (CANADAMEXICO) - } \\
\text { ECONOMY }\end{array}$ & NONE & KWH & UEFD & DISPOUT \\
\hline ETEXPF & EXPORTED POWER (CANADAMEXICO) - FIRM & NONE & KWH & UECP & DISPOUT \\
\hline ETGEN & TOTAL EWG GENERATION & NONE & $\mathrm{KWH}$ & UEFD & DISPOUT \\
\hline ETIMPD & IMPORTED POWER (CANADAMEXICO) COSTS & NONE & $8710^{\wedge} 6 \$$ & UEFD & DISPOUT \\
\hline ETIMPE & $\begin{array}{l}\text { IMPORTED POWER (CANADAMEXICO) - } \\
\text { ECONOMY }\end{array}$ & NONE & KWH & UEFD & DISPOUT \\
\hline
\end{tabular}


74

\begin{tabular}{|c|c|c|c|c|c|}
\hline H & 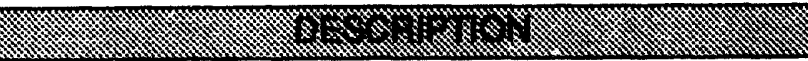 & - & Wh & $\times 4$ & 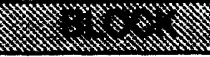 \\
\hline ETIMPF & IMPORTED POWER (CANADAMEXICO) - FIRM & NONE & KWH & UECP & DISPOUT \\
\hline EWGOWN & EWG - OWN USE & NONE & KWH & UEFD & DISPOUT \\
\hline EWGRCC & EWG POWER COSTS & NONE & $8710^{\wedge} 6 \$$ & UEFD & DISPOUT \\
\hline EWGREV & EWG POWER COSTS & NONE & $8710^{\wedge} 6 \$$ & UEFD & DISPOUT \\
\hline EWGRIC & EWG POWER COSTS & NONE & $8710^{\wedge} 6 \$$ & UEFD & DISPOUT \\
\hline EWGRMW & EWG POWER COSTS & NONE & $8710^{\wedge} 6 \$$ & UEFD & DISPOUT \\
\hline MNUMCR & $\begin{array}{l}\text { NUMBER OF CENSUS REGIONS (INCLUDES } \\
\text { TOTAL) }\end{array}$ & NONE & YEARS & UDAT & PARAMETR \\
\hline MNUMNR & $\begin{array}{l}\text { NUMBER OF NERC REGIONS (INCLUDES } \\
\text { TOTAL) }\end{array}$ & NONE & YEARS & UDAT & PARAMETR \\
\hline SECANNUALPEAK & $\begin{array}{l}\text { NON-COINCIDENT ANNUAL PEAK BY } \\
\text { CUSTOMER CLASS }\end{array}$ & UNRGN,NCLS,2 & MW & ULDSM & DSMTFEFP \\
\hline SECANNUALPEAK & $\begin{array}{l}\text { COINCIDENT ANNUAL PEAK BY CUSTOMER } \\
\text { CLASS }\end{array}$ & UNRGN,NCLS,1 & MW & ULDSM & DSMTFEFP \\
\hline SYSTEMLF & ANNUAL SYSTEM LOAD FACTOR & UNRGN & MW & ULDSM & DSMTFEFP \\
\hline TOTSECLOAD & SALES BY CUSTOMER CLASS & UNRGN,NCLS & MWH & ULDSM & DSMTFEFP \\
\hline
\end{tabular}




\begin{tabular}{|c|c|c|c|c|c|}
\hline - & - -1 & 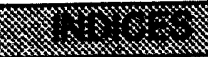 & W & 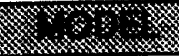 & w \\
\hline CURIYR & CURRENT YEAR INDEX & NONE & NUMBER & MAIN & NCNTRL \\
\hline MC_PGDP & GENERAL INFLATION INDEX $(1987=1.0)$ & UNYEAR & NOM.RATE & MACRO & MACOUT \\
\hline MC_RMPUAANS & $\begin{array}{l}\text { NATIONAL YIELD ON NEW AA UTILITY } \\
\text { BONDS }\end{array}$ & UNYEAR & NOM.RATE & MACRO & MACOUT \\
\hline UNYEAR & NUMBER OF YEARS & NONE & NUMBER & MAIN & ECONTROL \\
\hline
\end{tabular}


76

\begin{tabular}{|c|c|c|c|c|c|c|}
\hline Y.m. & 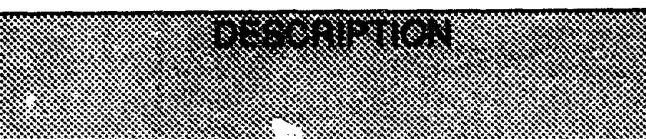 & (1) & 4 & 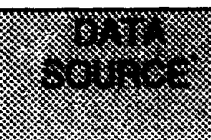 & 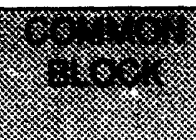 & 4 \\
\hline BKGAIN & BOOK GAIN ON SALE/LEASEBACK & NONE & MM \$ & RRA & NONE & SALELB \\
\hline CAPTIT & $\begin{array}{l}\text { PLANT TYPE NAMES FOR REPORT } \\
\text { HEADERS }\end{array}$ & NOCAP & NONE & EIA & NAME & EFPCNTL \\
\hline CONDR & $\begin{array}{l}\text { TAX DEPRECIATION SCHEDULES } \\
\text { UNDER TAX REFORM ACT OF } 1986\end{array}$ & $\begin{array}{l}\text { NYRCON, } \\
\text { NSCHED }\end{array}$ & FRACTION & TRA & TAX & EFPTAX \\
\hline DISPER & $\begin{array}{l}\text { FRACTION OF PLANT TOTALLY } \\
\text { DISALLOWED }\end{array}$ & $\overline{N P I}$ & FRACTION & RRA & PHASIN & PHASEIN \\
\hline DISPR1 & $\begin{array}{l}\text { FRAC. OF EXCESS CAPACITY } \\
\text { DISALLOWANCE TO TREAT AS } \\
\text { DISALLOW. }\end{array}$ & NONE & FRACTION & $E I A$ & NONE & PHASEIN \\
\hline DISPR2 & $\begin{array}{l}\text { FRAC. OF IMPRUDENCE } \\
\text { DISALLOWANCE TO TREAT AS } \\
\text { DISALLOW. }\end{array}$ & NONE & FRACTION & $\overline{E I A}$ & NONE & PHASEIN \\
\hline DISPRU & IMPRUDENCE DISALLOWANCE & NONE & FRACTION & RRA & NONE & PHASEIN \\
\hline DISXCS & EXCESS CAPACITY DISALLOWANCE & NONE & FRACTION & $\overline{R R A}$ & NONE & PHASEIN \\
\hline EDIVRT & DIVIDEND PAYOUT RATIO & NOWN & FRACTION & FORM1/EIA & EFPRCY & FINREG \\
\hline EGTXRT & GENERAL TAX RATE & NOWN & FRACTION & FORM1 & EFPRC & FINREG \\
\hline EIDIST & INDEX OF DISTRIBUTION BUILD & NONE & $\overline{N / A}$ & EIA & EFPGEN & NONE \\
\hline EILAG & $\begin{array}{l}\text { REGULATORY LAG (0 TO } 1 \text { YRS BY } \\
.25 ; \text { VAL }=1 \text { TO } 5 \text { BY } 1 \text { ) }\end{array}$ & NOWN & NONE & EIA & EFPRCY & FINREG \\
\hline EINUC & NUCLEAR PLANT TYPE INDEX & NONE & N/A & EIA & EFPGEN & NONE \\
\hline EITRAN & $\begin{array}{l}\text { PLANT CODE FOR TRANSMISSION } \\
\text { CAPITAL }\end{array}$ & NONE & N/A & EIA & EFPGEN & NONE \\
\hline EOBKLF & $\begin{array}{l}\text { BOOK LIFE FOR OLD ASSETS BY } \\
\text { PLANT TYPE }\end{array}$ & $\begin{array}{l}\text { NPTYP,NOW } \\
\text { N }\end{array}$ & YEARS & EIA & EFPGEN & FINREG \\
\hline
\end{tabular}




\begin{tabular}{|c|c|c|c|c|c|c|}
\hline Whon & \% & 1) & W & 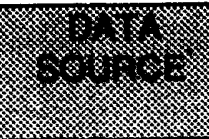 & 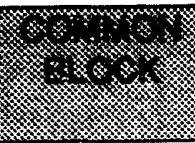 & 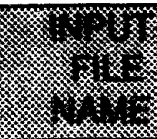 \\
\hline EOBKVL & $\begin{array}{l}\text { BOOKED VALUE OF EXISTING } \\
\text { ASSETS }\end{array}$ & $\begin{array}{l}\text { EOVYRS, } \\
\text { NPTYP,NOW } \\
\mathrm{N}\end{array}$ & MM \$ & $\begin{array}{l}\text { FORM } 1 \\
\text { EIA412 }\end{array}$ & EFPTMP & FINREG \\
\hline EODEPR & $\begin{array}{l}\text { BOOK DEPRECIATION RATE FOR } \\
\text { OLD ASSETS BY PLANT TYPE }\end{array}$ & $\begin{array}{l}\text { NPTYP,NOW } \\
\text { N }\end{array}$ & FRACTION & EIA & EFPGEN & FINREG \\
\hline EOTXLF & TAX LIFE FOR OLD ASSETS & $\begin{array}{l}\text { NPTYP,NOW } \\
\text { N }\end{array}$ & YEARS & EIA & EFPGEN & FINREG \\
\hline EOVYRS & NUMBER OF VINTAGE YEARS & NONE & YEARS & EIA & EFPGEN & FINREG \\
\hline ERCCA & $\begin{array}{l}\text { COST OF POST SERVICE CAPITAL } \\
\text { EXPENDITURES }\end{array}$ & NPROD & $\$ / K W$ & $E I A$ & EFPR & FINREG \\
\hline ESBKLF & $\begin{array}{l}\text { BOOK LIFE FOR NEW ASSETS BY } \\
\text { PLANT TYPE }\end{array}$ & $\begin{array}{l}\text { NPTYP,NOW } \\
\text { N }\end{array}$ & YEARS & EIA & EFPGEN & FINREG \\
\hline ESCPRF & $\begin{array}{l}\text { CONSTRUCTION PROFILE FOR EACH } \\
\text { PLANT TYPE }\end{array}$ & $\begin{array}{l}\text { NPTYP, } \\
\text { NYRCP }\end{array}$ & FRACTION & EIA & EFPGEN & FINREG \\
\hline$\overline{E S C W P P}$ & $\begin{array}{l}\% \text { CWIP IN RATE BASE FOR EACH } \\
\text { YEAR }\end{array}$ & NOWN & FRACTION & $\overline{E I A}$ & EFPRCY & FINREG \\
\hline ESDEPR & $\begin{array}{l}\text { DEPRECIATION RATE FOR BOOK } \\
\text { PURPOSES }\end{array}$ & $\begin{array}{l}\text { NPTYP,NOW } \\
\text { N }\end{array}$ & FRACTION & EIA & EFPGEN & FINREG \\
\hline ESEMDB & $\begin{array}{l}\text { EMBEDDED COST OF LONG TERM } \\
\text { DEBT - BASE YEAR }\end{array}$ & NOWN & FRACTION & $\begin{array}{l}\text { FORM 1 } \\
\text { EIA412 }\end{array}$ & EFPRC & FINREG \\
\hline ESEMPB & $\begin{array}{l}\text { EMBEDDED COST OF PREFERRED } \\
\text { STOCK - BASE YEAR }\end{array}$ & NOWN & FRACTION & FORM 1 & EFPRC & FINREG \\
\hline ESFLPR & $\begin{array}{l}\text { PERCENT OF DEFERRED TAX } \\
\text { FLOWED THROUGH }\end{array}$ & NOWN & FRACTION & EIA & EFPRC & FINREG \\
\hline ESFPDB & $\begin{array}{l}\% \text { FLOW THROUGH OF DEBT } \\
\text { PORTION OF AFUDC }\end{array}$ & NOWN & FRACTION & EIA & EFPRC & FINREG \\
\hline
\end{tabular}




\begin{tabular}{|c|c|c|c|c|c|c|}
\hline 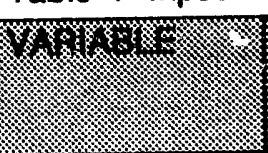 & - y & W & 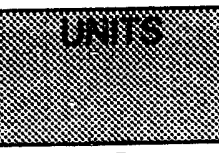 & 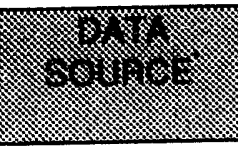 & 1 & 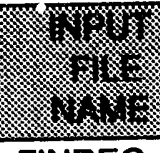 \\
\hline ESLCP & $\begin{array}{l}\text { LENGTH OF THE CONSTRUCTION } \\
\text { PERIOD FOR EACH BUILD }\end{array}$ & NPTYP & YEARS & EIA & EFPGEN & FINREG \\
\hline ESPRCE & $\begin{array}{l}\text { PERCENT OF CAPITALIZATION FROM } \\
\text { COMMON EQUITY }\end{array}$ & NOWN & FRACTION & FORM 1 & EFPRCY & FINREG \\
\hline ESPRLT & $\begin{array}{l}\text { PERCENT OF CAPITAL OBTAINED } \\
\text { WITH LONG TERM DEBT }\end{array}$ & NOWN & FRACTION & FORM 1 & EFPRCY & FINREG \\
\hline ESPRPS & $\begin{array}{l}\text { PERCENT OF CAPITALIZATION FROM } \\
\text { PREFERED STOCK }\end{array}$ & NOWN & FRACTION & FORM 1 & EFPRCY & FINREG \\
\hline ESPRST & $\begin{array}{l}\text { PERCENT OF CAPITAL OBTAINED } \\
\text { WITH SHORT TERM DEBT }\end{array}$ & NOWN & FRACTION & FORM 1 & EFPRCY & FINREG \\
\hline ESRBAF & $\begin{array}{l}\text { \% OF AFUDC/CWIP WHICH } \\
\text { RECEIVES OFFSET TREATMENT }\end{array}$ & $T$ & FRACTION & EIA & EFPRC & FINREG \\
\hline ESRITC & INVESTMENT TAX CREDIT RATE & $i$ & FRACTION & ERTA & TAX & EFPTAX \\
\hline ESRTCE & $\begin{array}{l}\text { COST OF COMMON EQUITY - FOR } \\
\text { EACH YEAR 1990-92 }\end{array}$ & NOWN & FRACTION & S\&PIS & EFPRCY & FINREG \\
\hline ESRTLT & $\begin{array}{l}\text { COST OF NEW LONG TERM DEBT - } \\
\text { FOR EACH YEAR 1990-92 }\end{array}$ & NOWN & FRACTION & $\begin{array}{l}\text { FORM } 1 \\
\text { EIA412 }\end{array}$ & EFPRCY & FINREG \\
\hline ESRTPS & $\begin{array}{l}\text { COST OF PREFERED STOCK - FOR } \\
\text { EACH YEAR 1990-92 }\end{array}$ & NOWN & FRACTION & FORM 1 & EFPRCY & FINREG \\
\hline ESRTST & $\begin{array}{l}\text { COST OF NEW SHORT TERM DEBT - } \\
\text { FOR EACH YEAR 1990-92 }\end{array}$ & NOWN & FRACTION & $\begin{array}{l}\text { FORM 1 } \\
\text { EIA412 } \\
\end{array}$ & EFPRCY & FINREG \\
\hline ESSLTX & SALES TAX RATE & NOWN & FRACTION & $E I A$ & EFPRC & FINREG \\
\hline ESTSHR & $\begin{array}{l}\text { PRIVATE/PUBLIC GENERATION } \\
\text { SHARE }\end{array}$ & NOWN & FRACTION & FORM 1/EIA & EFPRCY & FINREG \\
\hline ESTXLF & $\begin{array}{l}\text { TAX LIFE FOR NEW ASSETS UNDER } \\
\text { SYD METHOD }\end{array}$ & $\begin{array}{l}\text { NPTYP,NOW } \\
\text { N }\end{array}$ & YEARS & EIA & EFPGEN & FINREG \\
\hline
\end{tabular}




\begin{tabular}{|c|c|c|c|c|c|c|}
\hline H/W & 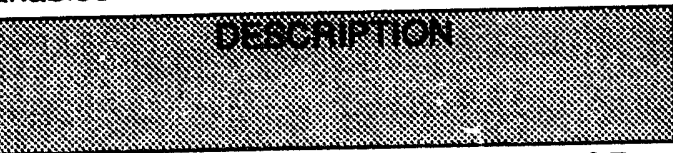 & \% & W11 & 1 & $(1)$ & 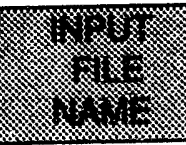 \\
\hline ESTXRC & $\begin{array}{l}\text { TAX RECOVERY CLASS (ERTA) FOR } \\
\text { NEW ASSETS BY PLANT TYPE }\end{array}$ & $\begin{array}{l}\text { NPTYP,NOW } \\
\text { N }\end{array}$ & N/A & ERTA & EFPGEN & FINREG \\
\hline ESTXRP & $\begin{array}{l}\text { TAX RECOVERY PERIOD (ERTA) FOR } \\
\text { EACH RECOVERY CLASS }\end{array}$ & NERTA & YEARS & ERTA & TAX & EFPTAX \\
\hline ESTXRS & $\begin{array}{l}\text { TAX RECOVERY SCHEDULE (ERTA) } \\
\text { FOR EACH RECOVERY CLASS }\end{array}$ & $\begin{array}{l}\text { NERTA, } \\
\text { NYRERT }\end{array}$ & FRACTION & ERTA & TAX & EFPTAX \\
\hline ETEMOM & $\begin{array}{l}\text { TRANSMISSION ENERGY-MILE O\&M } \\
\text { COSTS }\end{array}$ & $\begin{array}{l}\text { UNYEAR, } \\
\text { MNUMNR } \\
\end{array}$ & MM \$/EM & EIA & TRANS & ETRANS \\
\hline FRACRG & $\begin{array}{l}\text { FRACTIONS TO AGGREGATE/DISAG } \\
\text { INPUT REG'S TO PRINT REG'S }\end{array}$ & $\begin{array}{l}\text { MNUMNR, } \\
\text { NOPREG }\end{array}$ & N/A & EIA & RUN & EFPCNTL \\
\hline FREDTF & $\begin{array}{l}\text { FRACTION OF TOTAL FLOWED BACK } \\
\text { IN EACH YEAR (IF IEDT = 2) }\end{array}$ & NYREDT & FRACTION & EIA & TAX & EFPTAX \\
\hline IASMPT & $\begin{array}{l}\text { ASSUMPTION CODE FOR EACH } \\
\text { PHASE-IN }\end{array}$ & NONE & $1-3$ & RRA & NONE & PHASEIN \\
\hline IASSMP & $\begin{array}{l}\text { LOWEST ASSUMPTION CODE TO } \\
\text { USE IN THIS RUN (SCREENING VAR.) }\end{array}$ & NONE & $1-3$ & RRA & NONE & PHASEIN \\
\hline IBYRPI & 1ST YEAR OF PHASE-IN PERIOD & NPI & YEAR & RRA & PHASIN & PHASEIN \\
\hline IBYRSL & YEAR OF SALE/LEASEBACK PLAN & NSL & YEAR & RRA & SALELB & SALELB \\
\hline ICAPYR & $\begin{array}{l}\text { YEAR IDC PROPOSAL IS } \\
\text { IMPLEMENTED }\end{array}$ & NONE & YEAR & TRA & TAX & EFPTAX \\
\hline IEDT & $\begin{array}{l}\text { METHOD USED FOR FLOW BACK OF } \\
\text { EXCESS DEFERRED TAXES }\end{array}$ & NONE & 1,2 & EIA & TAX & EFPTAX \\
\hline IPCOMP & $\begin{array}{l}\text { FLAGS INDICATING THE OPERATING } \\
\text { COMPONENTS TO PRINT }\end{array}$ & NCOMP+1 & 0,1 & EIA & RUN & EFPCNTL \\
\hline IPOWN & $\begin{array}{l}\text { FLAGS INDICATING WHICH } \\
\text { OWNERSHIP CLASSES TO PRINT }\end{array}$ & NOWN +1 & 0,1 & EIA & RUN & EFPCNTL \\
\hline
\end{tabular}




\begin{tabular}{|c|c|c|c|c|c|c|}
\hline (1) & 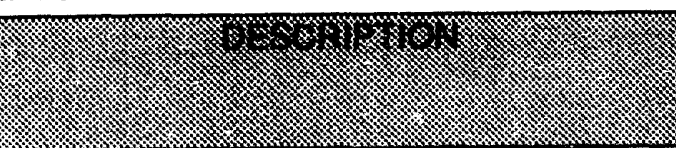 & \% & \% & 8 & 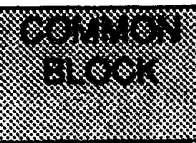 & (1) \\
\hline IPREG & $\begin{array}{l}\text { FLAGS INDICATING THE REGIONS } \\
\text { TO BE PRINTED }\end{array}$ & NOPREG +1 & 0,1 & EIA & RUN & EFPCNTL \\
\hline IPRPT & $\begin{array}{l}\text { FLAGS :NDICATING WHICH REPORTS } \\
\text { (LARGE/SMALL) TO PRINT }\end{array}$ & 2 & 0,1 & EIA & RUN & EFPCNTL \\
\hline IRDPI & $\begin{array}{l}\text { CAPITALIZE RETURN ON DEFERRED } \\
\text { COST? }(1=\mathrm{YES}, 2=\mathrm{NO})\end{array}$ & NPI & 1,2 & RRA & PHASIN & PHASEIN \\
\hline IREAL\$ & $\begin{array}{l}\text { FLAG INDICATING IF REPORTS ARE } \\
\text { IN REAL OR NOMINAL } \$\end{array}$ & NONE & 0,1 & EIA & RUN & EFPCNTL \\
\hline |ROP| & $\begin{array}{l}\text { OWNERSHIP TYPE OF PHASE-IN } \\
\text { PLAN }\end{array}$ & 2,NPI & 1,2 & RRA & PHASIN & PHASEIN \\
\hline IROPI & REGION OF PHASE-IN PLAN & $1, \mathrm{NPI}$ & $1-14$ & RRA & PHASIN & PHASEIN \\
\hline IROSL & $\begin{array}{l}\text { OWNERSHIP TYPE OF } \\
\text { SALE/LEASEBACK }\end{array}$ & $2, N S L$ & 1,2 & RRA & SALELB & SALELB \\
\hline IROSL & REGION OF SALE/LEASEBACK & $1, \mathrm{NSL}$ & 1-14 & RRA & SALELB & SALELB \\
\hline IRSYP & $\begin{array}{l}\text { FIRST YEAR IN WHICH NEW GEN. } \\
\text { PLANT USES TRA DEPREC. SCHED. }\end{array}$ & NONE & YEAR & TRA & TAX & EFPTAX \\
\hline IRSYTD & $\begin{array}{l}\text { FIRST YEAR IN WHICH NEW T\&D } \\
\text { PLANT USES TRA DEPREC. SCHED. }\end{array}$ & NONE & YEAR & TRA & TAX & EFPTAX \\
\hline IYREDT & $\begin{array}{l}\text { FIRST YEAR IN WHICH EXCESS } \\
\text { SHOULD BE FLOWED BACK }\end{array}$ & NONE & YEAR & TRA & TAX & EFPTAX \\
\hline IYRITC & $\begin{array}{l}\text { YEAR ITC PROPOSAL IS } \\
\text { IMPLEMENTED } \\
\end{array}$ & NONE & YEAR & TRA & TAX & EFPTAX \\
\hline IYRRL\$ & $\begin{array}{l}\text { YEAR IN WHICH TO REPORT REAL } \\
\text { DOLLARS }\end{array}$ & NONE & YEAR & $E I A$ & RUN & EFPCNTL \\
\hline JYRITC & $\begin{array}{l}\text { FIRST START YEAR OF EFFECTED } \\
\text { PLANTS }\end{array}$ & NONE & YEAR & TRA & TAX & EFPTAX \\
\hline
\end{tabular}


81

\begin{tabular}{|c|c|c|c|c|c|c|}
\hline Yro & 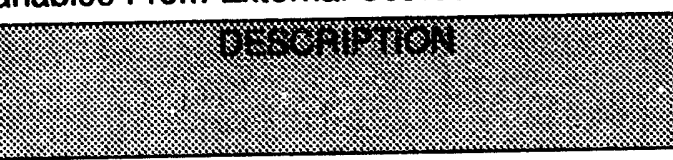 & \% & 8 & 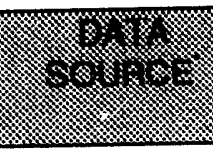 & 1 & 18 \\
\hline LPI & LENGTH OF PHASE-IN PLAN & NPI & YEARS & RRA & PHASIN & PHASEIN \\
\hline NAME3 & REPORT TITLE & NONE & $\mathrm{N} / \mathrm{A}$ & EIA & NAME & EFPCNTL \\
\hline NCOST & NUMBER OF COST CATEGORIES & NONE & N/A & EIA & $\overline{C A}$ & EFPALL \\
\hline NOCAP & \# OF PLANT TYPE REPORTS & NONE & N/A & EIA & RUN & EFPCNTL \\
\hline NOPREG & NUMBER OF PRINT REGIONS & NONE & N/A & EIA & RUN & EFPCNTL \\
\hline NPI & TOTAL NUMBER OF PHASE-IN PLANS & NONE & N/A & RRA & PHASIN & PHASEIN \\
\hline NSL & $\begin{array}{l}\text { TOTAL NUMBER OF } \\
\text { SALE/LEASEBACK TRANSACTIONS }\end{array}$ & NONE & N/A & RRA & SALELB & SALELB \\
\hline NTECH & $\begin{array}{l}\text { NUMBER OF ALLOCATION } \\
\text { TECHNIQUES }\end{array}$ & NONE & $\mathrm{N} / \mathrm{A}$ & EIA & $\overline{C A}$ & EFPALL \\
\hline NUMCAP & $\begin{array}{l}\text { \# OF PLANT TYPES IN EACH PLANT } \\
\text { TYPE REPORT }\end{array}$ & NOCAP & $\mathrm{N} / \mathrm{A}$ & EIA & RUN & EFPCNTL \\
\hline NYREDT & $\begin{array}{l}\text { NUMBER OF YEARS TO FLOW BACK } \\
\text { (IF IEDT }=2 \text { ) }\end{array}$ & NONE & YEARS & EIA & TAX & EFPTAX \\
\hline PIBKLF & BOOK LIFE OF PHASED-IN PLANT & NONE & YEARS & EIA & PHASIN & PHASEIN \\
\hline PIBKVL. & $\begin{array}{l}\text { BOOK VALUE OF PLANT TO BE } \\
\text { PHASED-IN }\end{array}$ & NPI & $M M \$$ & RRA & PHASIN & PHASEIN \\
\hline PIDFS & $\begin{array}{l}\text { CUMULATIVE FRACTION OF TOTAL } \\
\text { COST PHASED-IN BY YEAR } \\
\end{array}$ & NYRPI,NPI & FRACTION & RRA & PHASIN & PHASEIN \\
\hline PIRCS & $\begin{array}{l}\text { FRAC. OF REMAINING DEFERRED } \\
\text { REV'S. TO BE RECOVERED BY } \\
\text { CLASS }\end{array}$ & NYRPI,NPI & FRACTION & RRA & PHASIN & PHASEIN \\
\hline PITXBS & $\begin{array}{l}\text { TAX BASIS AS A FRACTION OF } \\
\text { BOOKED COST OF PHASE-IN PLANT }\end{array}$ & NONE & FRACTION & EIA & PHASIN & PHASEIN \\
\hline
\end{tabular}




\begin{tabular}{|c|c|c|c|c|c|c|}
\hline \% & 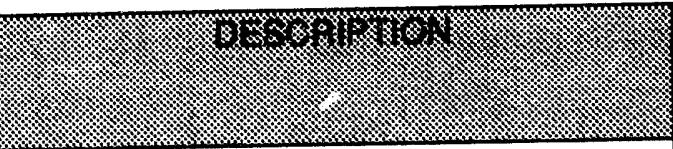 & $4 \leqslant$ & y & 9 & (1) & 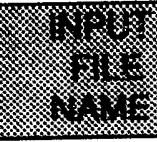 \\
\hline REVHRCI & $\begin{array}{l}\text { THE TOTAL REVENUES ALLOCATED } \\
\text { TO THE RESIDENTIAL, COMMERCIAL, } \\
\text { AND INDUTRIAL CLASSES }\end{array}$ & NONE & MM \$ & $\begin{array}{l}\text { FORM1 } \\
\text { EIA412 }\end{array}$ & EFPINT & N/A \\
\hline $\begin{array}{l}\text { SAL90 } \\
\text { SAL91 }\end{array}$ & $\begin{array}{l}\text { THE SUM OF THE SALES TO THE } \\
\text { RESIDENTIAL, COMMERCIAL, AND } \\
\text { INDUSTRIAL CLASSES IN } 1990 \text { AND } \\
1991\end{array}$ & ICLS,NRGN & KWH & $\begin{array}{l}\text { FORM1 } \\
\text { EIA412 }\end{array}$ & EFPINT & N/A \\
\hline SLLP & ANNUAL LEASE PAYMENT & NSL & MM \$ & RRA & SALELB & SALELB \\
\hline SLPROC & GROSS SALE PROCEEDS & NSL & MM \$ & RRA & SALELB & SALELB \\
\hline SLTAXS & $\begin{array}{l}\text { INCOME TAXES ON } \\
\text { SALES/LEASEBACK TRANSACTIONS }\end{array}$ & NSL & MM \$ & RRA & SALELB & SALELB \\
\hline SLTERM & TERM OF THE LEASE (YEARS) & NSL & YEARS & RRA & SALELB & SALELB \\
\hline TRABDE & $\begin{array}{l}\text { TOTAL ACCUMULATED BOOK } \\
\text { DEPRECIATION - BASE YEAR } \\
\end{array}$ & NOWN & $M M \$$ & $\begin{array}{l}\text { FORM 1 } \\
\text { EIA412 }\end{array}$ & NONE & FINREG \\
\hline TRAMD & $\begin{array}{l}\text { TOTAL ASSETS MINUS DEFERRALS - } \\
\text { BASE :EAR }\end{array}$ & NOWN & MM \$ & $\begin{array}{l}\text { FORM } 1 \\
\text { EIA412 } \\
\end{array}$ & NONE & FINREG \\
\hline TRCS & $\begin{array}{l}\text { TOTAL COMMON STOCK - BASE } \\
\text { YEAR }\end{array}$ & NOWN & $M M \$$ & FORM 1 & NONE & FINREG \\
\hline TRDITC & $\begin{array}{l}\text { ACCUMULATED DEFERRED ITC - } \\
\text { BASE YEAR }\end{array}$ & NOWN & MM \$ & FORM 1 & NONE & FINREG \\
\hline TROB & $\begin{array}{l}\text { TOTAL LONG TERM DEBT - BASE } \\
\text { YEAR }\end{array}$ & NOWN & MM \$ & $\begin{array}{l}\text { FORM } 1 \\
\text { EIA412 }\end{array}$ & NONE & FINREG \\
\hline TRPRDF & $\begin{array}{l}\text { TOTAL DEFERRED TAXES - BASE } \\
\text { YEAR }\end{array}$ & NOWN & MM \$ & FORM 1 & NONE & FINREG \\
\hline TRPS & $\begin{array}{l}\text { TOTAL PREFERRED STOCK - BASE } \\
\text { YEAR }\end{array}$ & NOWN & $M M \$$ & FORM 1 & NONE & FINREG \\
\hline
\end{tabular}


83

\begin{tabular}{||l|l|l|l|l|l|l||}
\hline \hline Table 4 Input Variables From External Sources & & & \\
\hline
\end{tabular}




\begin{tabular}{|c|c|c|c|c|c|}
\hline W & $\ldots$ & W & +2 & 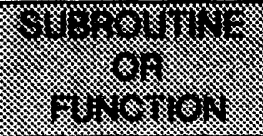 & 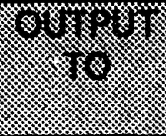 \\
\hline BALSHT & BALANCE SHEET REPORT & 26 & MM \$ & STMTS & REPORT \\
\hline CANPLT & CANCELED PLANT REPORT & 3 & MM \$ & STMTS & REPORT \\
\hline CAPREQ & CAPITAL REQUIREMENTS REPORT & NOCAP, 6 & MM \$ & STMTS & REPORT \\
\hline COST & COMPONENTS OF COST & NCOST,NCOMP & MM \$ & STMTS & REPORT \\
\hline COSTFC & $\begin{array}{l}\text { FACTORS TO ALLOCATE COST POOLS TO RATE } \\
\text { CLASSES }\end{array}$ & $\begin{array}{l}\text { NCOST,NCLASS, } \\
\text { NCOMP }\end{array}$ & FRACTION & ALLOCT & EFPRP2 \\
\hline CSITCAP & COST OF CAPITAL REPORT & 11 & FRACTION & STMTS & REPORT \\
\hline DEMFAC & $\begin{array}{l}\text { FACTORS FOR SECTOR SPLITS BY } \\
\text { ALLOCATION TECHNIQUE }\end{array}$ & NTECH,NCLASS & FRACTION & $\overline{A L i F A C}$ & $\mathrm{CA}$ \\
\hline DISPER & FRACTION OF PLANT TOTALLY DISALLOWED & NPI & FRACTION & El RDPI & PHASIN \\
\hline$\overline{\mathrm{EB}} \overline{\mathrm{AFDC}}$ & $\begin{array}{l}\text { AMORITIZATION OF AFUDC TAX SAVINGS FROM } \\
\text { NEW ASSETS }\end{array}$ & NOWN,IBNUM & $M M \$$ & ELCWIP & EFPBLD \\
\hline EBASVL & TAX BASIS OF ASSETS & NOWN,IBNUM & MM \$ & ELCWIP & EFPBLD \\
\hline EBBKVL & BOOK VALUE OF ASSETS & NOWN,IBNUM & MM \$ & ELCWIP & EFPBLD \\
\hline EBDITC & DEFERRED ITC FROM NEW ASSETS & NOWN,IBNUM & MM \$ & ELITC & EFPBLD \\
\hline EBRCWP & CWIP IN RATE BASE BY BUILD & NOWN,IBNUM & MM \$ & ELCWIP & EFPBLD \\
\hline EBYCWP & $\begin{array}{l}\text { ANNUAL CONSTRUCTION EXPENDITURES BY } \\
\text { PLANT }\end{array}$ & NOWN,IBNUM & MM \$ & ELCWIP & EFPBLD \\
\hline EDISNT & NET DISALLOWED PLANT FOR YEAR & NOWN & MM \$ & ELPHIN & EFPINT \\
\hline EDISYR & GROSS PLANT DISALLOWED IN THIS YEAR & NOWN & $M M \$$ & ELPHIN & EFPINT \\
\hline EPAFDC & BOOKED AFUDC IN CURRRENT YEAR & NPTYP,NOWN & MM \$ & ELCWIP & EFPINT \\
\hline EPIDEF & $\begin{array}{l}\text { TCTAL CUMULATIVE DEFERRED PHASE-IN } \\
\text { REVENUES }\end{array}$ & NOWN & MM \$ & ELPHIN & EFPINT \\
\hline EPIND & $\begin{array}{l}\text { NET-DEFERRED PHASE-IN REVENUES FOR } \\
\text { YEAR }\end{array}$ & NOWN & MM \$ & ELPHIN & EFPINT \\
\hline
\end{tabular}




\begin{tabular}{|c|c|c|c|c|c|}
\hline (1) & $4 \%$ & ) & 4 & 40 & 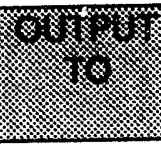 \\
\hline EPIRET & $\begin{array}{l}\text { CAPITALIZED RETURN ON DEFERRED } \\
\text { REVENUES FOR YEAR }\end{array}$ & NOWN & MM \$ & ELPHIN & EFPINT \\
\hline EPONLN & $\begin{array}{l}\text { BOOK VALUE OF CAPACITY COMPLETED IN } \\
\text { CURRENT YEAR }\end{array}$ & NगTYP,NOWN & MM \$ & ELCWIP & EFPINT \\
\hline EPRICE & PRICES PASSED TO NEMS REPORT WRITER & $\begin{array}{l}\text { NCLASS,NSECT, } \\
\text { MNUMNR }\end{array}$ & MM \$ & RATES & EFPRP2 \\
\hline EPYCWP & $\begin{array}{l}\text { DIRECT CONSTRUCTION EXPENDITURES FOR } \\
\text { YEAR (NO AFUDC) }\end{array}$ & NPTYP,NOWN & $M M \$$ & ELCWIP & EFPINT \\
\hline ERABDE & $\begin{array}{l}\text { ACCUMULATED BOOK DEPRECIATION ALL } \\
\text { ASSETS }\end{array}$ & NOWN & $M M \$$ & ELBKDP & EFPINT \\
\hline ERAFDC & $\begin{array}{l}\text { AMORTIZATION OF AFUDC TAX SAVINGSFOR } \\
\text { ALL ASSETS }\end{array}$ & NOWN & $M M \$$ & ELTSAF & EFPINT \\
\hline ERAFDL & $\begin{array}{l}\text { RATE BASE ADJ. FOR PLTS. COMING ON IN MID } \\
\text { YR. (EOY RB. ONLY) }\end{array}$ & NOWN & $M M \$$ & ELCWIP & EFPINT \\
\hline ERAITC & AMORTIZATION/YEAR OF DEFERRED ITC & NOWN & MM \$ & ELITC & EFPINT \\
\hline ERAMD & TOTAL VALUE OF ASSETS TO BE FINANCED & NOWN & MM \$ & ELINEX & EFPINT \\
\hline ERATSD & $\begin{array}{l}\text { ACCELERATED DEPFIECIATION TAX SAVINGS - } \\
\text { DEFERRED }\end{array}$ & NOWN & MM \$ & ELTXDP & EFPINT \\
\hline ERATSF & $\begin{array}{l}\text { ACCELERATED TAX DEPRECIATION SAVINGS - } \\
\text { FLOWED THROUGH }\end{array}$ & NOWN & $M M \$$ & ELTXDP & EFPINT \\
\hline ERAVCE & $\begin{array}{l}\text { AVERAGE COMMON EQUITY BALANCE IN } \\
\text { CURRENT YEAR }\end{array}$ & NOWN & MM \$ & ELINEX & EFPINT \\
\hline ERBCWP & TOTAL BOOKED C'SIP (INCLUDES AFUDC) & NOWN & $M M \$$ & ELCWIP & EFPINT \\
\hline ERBDE & BOOK DEPRECIATION FOR ALL ASSETS & NOWN & MM \$ & ELBKDP & EFPINT \\
\hline ERBDED & $\begin{array}{l}\text { DEPRECIATION EXPENSE FOR DISALLOWED } \\
\text { PLANT }\end{array}$ & NOWN & MM \$ & ELPHIN & EFPINT \\
\hline
\end{tabular}




\begin{tabular}{|c|c|c|c|c|c|}
\hline (restis & 8 & W) & (1) & (1) & 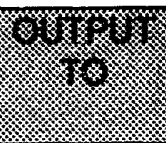 \\
\hline ERBNDL & LAST YEARS LONG TERM DEBT & NOWN & $M M \Phi$ & ELINEX & EFPINT \\
\hline ERBOND & NEW LONG TERM DEBT & NOWN & $M M \$$ & ELINEX & EFPINT \\
\hline ERBTIR & BOOK VALUE OF ALL RETIREMENTS & NOWN & $M M \$$ & ELBKDP & EFPINT \\
\hline ERCIDC & $\begin{array}{l}\text { CAPITALIZED INTEREST DURING } \\
\text { CONSTRUCTION FOR TAXES }\end{array}$ & NOWN & $M M \$$ & ELCWIP & EFPINT \\
\hline ERCNAD & $\begin{array}{l}\text { ACCUMULATED AMORTIZATION FOR CANCELED } \\
\text { PLANT }\end{array}$ & NOWN & MM \$ & ELBKDP & EFPINT \\
\hline ERCNBV & BOOK VALUE OF CANCELED PLANT & NOWN & MM \$ & ELBKDP & EFPINT \\
\hline ERDLRB & $\begin{array}{l}\text { CHANGE IN RATE BASE DUE TO BUILDS GOING } \\
\text { INTO RB ON JAN. } 1\end{array}$ & NOWN & MM \$ & ELCWIP & EFPINT \\
\hline EREDTF & $\begin{array}{l}\text { AMOUNT OF EXCESS TO BE FLOWED } \\
\text { THROUGH THIS YEAR }\end{array}$ & NOWN & MM \$ & ELEDT & EFPINT \\
\hline ERFDC & TOTAL ANNUAL AFUDC & NOWN & $\mathrm{MM} \$$ & ELCV"P & EFPINT \\
\hline ERFDCD & DEBT PORTION OF TOTAL AFUDC & NOWN & MM \$ & ELCWIP & EFPINT \\
\hline ERFDCE & EQUITY PORTION OF TOTAL AFUDC & NOWN & MM \$ & ELCWIP & EFPINT \\
\hline ERFFDC & $\begin{array}{l}\text { AMOUNT OF AFUDC TAX SAVINGS FLOWED } \\
\text { THROUGH }\end{array}$ & NOWN & MM \$ & ELCWIP & EFPINT \\
\hline ERFFDC & $\begin{array}{l}\text { AMOUNT OF AFUDC TAX SAVINGS FLOWED } \\
\text { THROUGH }\end{array}$ & NOWN & MM \$ & ELCWIP & EFPINT \\
\hline EPiFITC & $\begin{array}{l}\text { AMOUNT OF ITC FLOWED THROUGH FOR } \\
\text { RATEMAKING }\end{array}$ & NOWN & MM \$ & ELITC & EFPINT \\
\hline ERLIEX & LONG TERM INTEREST EXPENSE & NOWN & $M M \$$ & ELINEX & EFPINT \\
\hline ERNFSN & NUCLEAR FUEL STOCK IN NOMINAL DOLLARS & NOWN & $M M \$$ & ELCEXP & EFPINT \\
\hline ERNITC & $\begin{array}{l}\text { TOTAL DEFERRED ITC NET OF AMORITIZED } \\
\text { DEFERRALS }\end{array}$ & NOWN & MM \$ & ELITC & EFPINT \\
\hline
\end{tabular}




\begin{tabular}{|c|c|c|c|c|c|}
\hline Tabue Outp & 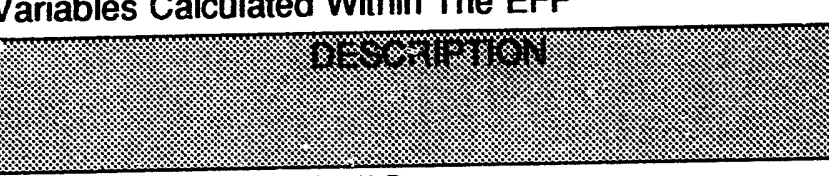 & . & (1) & 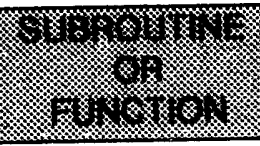 & 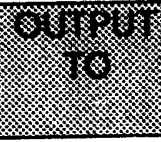 \\
\hline EROB & OUTSTANDING BONDS & NOWN & MM \$ & ELINEX & EFPINT \\
\hline EROBL & LAST YEARS OUTSTANDING BONDS & NOWN & $M M \$$ & ELINEX & EFPINT \\
\hline EROFFS & TOTAL AFUDC OFFSET & NOWN & $M M \$$ & ELCWIP & EFPINT \\
\hline ERPF & $\begin{array}{l}\text { TOTAL OUTSTANDING PREFERRED STOCK } \\
\text { ISSUED BEFORE BASE YEAR }\end{array}$ & NOWN & $M M \$$ & ELINEX & EFPINT \\
\hline ERPRDF & PROVISION FOR DEFERRED TAXES & NOWN & MM \$ & ELTXDP & EFPINT \\
\hline ERPREF & TOTAL NEW PREFERRED STOCK & NOWN & MM \$ & ELINEX & EFPINT \\
\hline ERPRTX & PROPERTY TAX ON BOOK VALUE OF PLANTS & NOWN & MM \$ & ELCWIP & EFPINT \\
\hline ERPSDV & $\begin{array}{l}\text { TOTAL PREFERRED STOCK DIVIDENDS IN } \\
\text { CURRENT YEAR }\end{array}$ & NOWN & $M M \$$ & ELINEX & EFPINT \\
\hline ERRB & RATE BASE & NOWN & MM $\$$ & ELREVS & EFPINT \\
\hline ERRBRR & $\begin{array}{l}\text { RATE BASE USED FOR SETTING REVENUE } \\
\text { REQUIREMENTS }\end{array}$ & NOWN & MM \$ & ELREVS & EFPINT \\
\hline ERRCWP & TOTAL CWIP IN RATE BASE & NOWN & MM \$ & ELCWIP & EFPINT \\
\hline ERRVLG & $\begin{array}{l}\text { ACTUAL REVENUES DEPENDING ON IAG } \\
\text { SCENARIO }\end{array}$ & NOWN & $M M \$$ & ELREVS & EFPINT \\
\hline ERRVRQ & $\begin{array}{l}\text { REVENUE REQUIREMENTS FOR CURRENT } \\
\text { YEAR }\end{array}$ & NOWN & $M M \$$ & ELREVS & EFPINT \\
\hline ERSIEX & SHORT TERM INTEREST EXPENSE & NOWN & MM \$ & ELINEX & EFPINT \\
\hline ERSLTX & SALES TAX ON YEARLY CWIP EXPENDITURES & NOWN & $M M \$$ & ELCWIP & EFPINT \\
\hline ERTDRG & $\begin{array}{l}\text { TAX DEPRECIATION USED FOR REGULATC } 3 Y \\
\text { PURPOSES }\end{array}$ & NOWN & MM \$ & ELTXD̄P & EFPINT \\
\hline ERTDWO & $\begin{array}{l}\text { TAX DEPRECIATION W/O ACCELERATION FOR } \\
\text { ALL ASSETS }\end{array}$ & NOWN & $M M \$$ & ELBKDP & EFPINT \\
\hline ERTFLN & TOTAL FUEL COSTS IN NOMINAL DOLLARS & NOWN & MM \$ & ELCEXP & EFPINT \\
\hline
\end{tabular}




\begin{tabular}{|c|c|c|c|c|c|}
\hline$(8)$ & 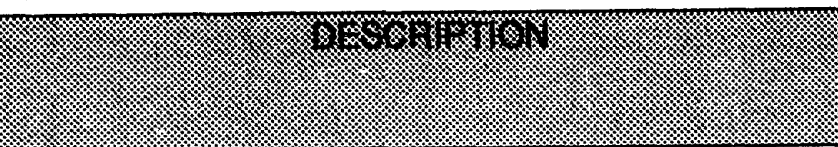 & . & y & $\begin{array}{ll}2 \\
2\end{array}$ & 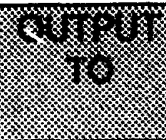 \\
\hline ERTIEX & TOTAL INTEREST EXPENSE & NOWN & MM \$ & ELINEX & EFPINT \\
\hline ERTOMN & TOTAL O\&M IN NOMINAL DOLLARS & NOWN & $M M \$$ & ELCEXP & EFPINT \\
\hline ERTOMT & $\begin{array}{l}\text { TOTAL TRANSMISSION RELATED O\&M } \\
\text { EXPENSES REAL DOLLARS }\end{array}$ & NOWN & $M M \$$ & ELTRAN & EFPINT \\
\hline ERTUP & TOTAL UTILITY PLANT IN SERVICE & NOWN & $M M \$$ & ELBKDP & EFPINT \\
\hline ERWC & WORKING CAPITAL & NOWN & MM \$ & ELCEXP & EFPINT \\
\hline ERXFDC & DEFERRED AFUDC TAX SAVINGS & NOWN & MM \$ & ELCWIP & EFPINT \\
\hline ERYCWP & TOTAL YEARLY CWIP W/O AFUDC & NOWN & MM \$ & ELCWIP & EFPINT \\
\hline ESAFDC & AFUDC RATE & NOWN & FRACTION & ELADCR & EFPINT \\
\hline ESEMDT & EMBEDDED COST OF DEBT & NOWN & FRACTION & ELINEX & EFPINT \\
\hline ESEMPS & EMBEDDED COST OF PREFERRED STOCK & NOWN & FRACTION & ELINEX & EFPINT \\
\hline ESLAGN & $\begin{array}{l}\text { TOTAL REGIONAL AMORTIZATION OF GAIN } \\
\text { FROM SALE/LEASEBACK }\end{array}$ & NOWN & $M M \$$ & ELSL & EFPINT \\
\hline ESLLP & TOTAL REGIONAL LEASE PAYMENT & NOWN & MM \$ & ELSL & EFPINT \\
\hline ESLNDG & TOTAL REGIONAL NET DEFERRED GAIN & NOWN & MM \$ & ELSL & EFPINT \\
\hline ESLPRC & NET OF TAX SALES PROCEEDS & NOWN & MM \$ & ELSL & EFPINT \\
\hline ESRR & $\begin{array}{l}\text { RATE OF RETURN (WEIGHTED AVERAGE COST } \\
\text { OF CAPITAL) }\end{array}$ & NOWN & FRACTION & ELREVS & EFPINT \\
\hline ESRTCE & COST OF COMMON EQUITY & NOWN & FRACTION & CAPCOST & EFPINT \\
\hline ESRTLT & COST OF NEW LONG TERM DEBT & NOWN & FRACTION & CAPCOST & EFPINT \\
\hline ESRTPS & COST OF NEW PREFERRED STOCK & NOWN & FRACTION & CAPCOST & EFPINT \\
\hline ESRTST & COST OF SHORT TERM DEBT & NOWN & FRACTION & CAPCOST & EFPINT \\
\hline ESWACD & DEBT FRACTION OF AFUDC & NOWN & FRACTION & ELADCR & EFPINT \\
\hline FUNDS & SOURCES/USES OF FUNDS REPORT & 21 & MM \$ & STMTS & REPORT \\
\hline
\end{tabular}




\begin{tabular}{|c|c|c|c|c|c|}
\hline W & 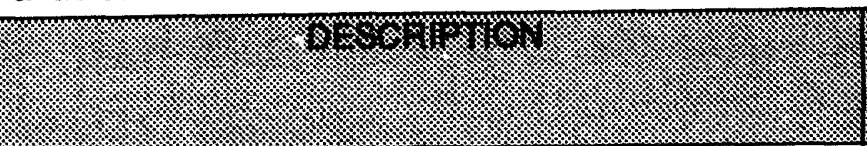 & (1) & 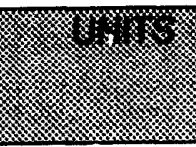 & 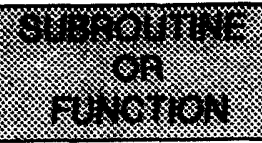 & 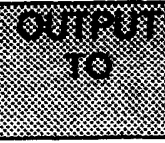 \\
\hline PIDEF & TOTAL CUMULATIVE DEFERRED REVENUES & NPI & MM \$ & ELRDPI & PHASIN \\
\hline REV & $\begin{array}{l}\text { REVENUES BY RATE CLASS AND STAGE OF } \\
\text { PRODUCTION }\end{array}$ & $\begin{array}{l}\text { NCLASS, } \\
\text { NCOMP+1 }\end{array}$ & MM \$ & ALLOCT & EFPRP2 \\
\hline REVREQ & REVENUE REQUIREMENTS REPORT & 24 & MM \$ & STMTS & REPORT \\
\hline SALES & SALES REPORT & 2 & MM \$ & STMTS & REPORT \\
\hline SLGAIN & $\begin{array}{l}\text { NET OF TAX GAIN OVER BOOK VALUE FROM } \\
\text { SALE }\end{array}$ & NSL & MM \$ & ELRDSL & SALELB \\
\hline TAXINC & TAX INCOME REPORT & 19 & MM \$ & STMTS & REPORT \\
\hline TBALSH & TEMPORARY BALANCE SHEET REPORT & UNYEAR,26 & MM \$ & TMPSET & EFPWRT \\
\hline TCANPL & TEMPORARY CANCELED PLANT REPORT & UNYEAR,3 & MM \$ & TMPSET & EFPWRT \\
\hline TCAPRE & TEMPORARY CAPITAL REQUIREMENTS REPORT & $\begin{array}{l}\text { UNYEAR,NOCAP, } \\
6\end{array}$ & MM \$ & TMPSET & EFPWRT \\
\hline TCSTCA & TEMPORARY COST OF CAPITAL REPORT & UNYEAR,11 & MM \$ & TMPSET & EFPWRT \\
\hline TFUNDS & $\begin{array}{l}\text { TEMPORARY SOURCES/USES OF FUNDS } \\
\text { REPORT }\end{array}$ & UNYEAR,21 & MM \$ & TMPSET & EFPWRT \\
\hline TREVRE & $\begin{array}{l}\text { TEMPORARY REVENUE REQUIREMENTS } \\
\text { REPORT }\end{array}$ & UNYEAR,24 & MM \$ & TMPSET & EFPWRT \\
\hline TSALES & TEMPORARY SALES REPORT & UNYEAR,2 & MM \$ & TMPSET & EFPWRT \\
\hline TTAXIN & TEMPORARY TAX INCOME REPORT & UNYEAR,19 & $M M \$$ & TMPSET & EFPWRT \\
\hline TXINCS & TEMPORARY INCOME STATEMENT REPORT & UNYEAR,20 & MM \$ & TMPSET & EFPWRT \\
\hline UOABDE & $\begin{array}{l}\text { ACCUM BOOK DEP FOR EXISTING ASSETS BY } \\
\text { VINTAGE YEAR }\end{array}$ & $\begin{array}{l}\text { EOVYRS,NPTYP, } \\
\text { NOWN }\end{array}$ & MM \$ & ELEA & EFPR \\
\hline UOAFDC & $\begin{array}{l}\text { AMORT OF AFDC BY PLANT, REGION, AND } \\
\text { OWNERSHIP * }\end{array}$ & $\begin{array}{l}\text { EOVYRS,NPTYP, } \\
\text { NOWN }\end{array}$ & MM \$ & ELEA & EFPR \\
\hline
\end{tabular}


90

\begin{tabular}{|c|c|c|c|c|c|}
\hline 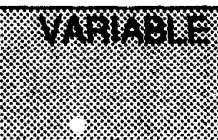 & (3) - \& & \%) & Yy & $\frac{1}{21}$ & 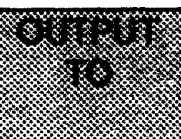 \\
\hline UOAITC & $\begin{array}{l}\text { AMORITIZATION OF DEFERRED ITC FROM } \\
\text { EXISTING ASSETS }\end{array}$ & $\begin{array}{l}\text { EOVYRS,NPTYP, } \\
\text { NOWN }\end{array}$ & MM \$ & ELEA & EFPR \\
\hline UOASVL & $\begin{array}{l}\text { ASSET VALUE OF EXISTING ASSETS BY } \\
\text { VINTAGE YEAR }\end{array}$ & $\begin{array}{l}\text { EOVYRS,NPTYP, } \\
\text { NOWN }\end{array}$ & MM \$ & ELEA & EFPR \\
\hline UOBKVL & $\begin{array}{l}\text { BOOKED VALUE OF EXISTING ASSETS BY } \\
\text { VINTAGE YEAR }\end{array}$ & $\begin{array}{l}\text { EOVYRS,NPTYP, } \\
\text { NOWN }\end{array}$ & MM \$ & ELEA & EFPR \\
\hline UREDTF & SAME AS EREDTF, BUT BY YEAR AND REGION & $\begin{array}{l}\text { MNUMNR, } \\
\text { UNYEAR }\end{array}$ & MM \$ & ELEDT & EFPINT \\
\hline XINCST & INCOME STATEMENT REPORT & 20 & MM \$ & STMTS & REPORT \\
\hline
\end{tabular}




\section{Appendix D Bibliography}

1. Documentation of the National Utility Financial Statement Model (August 1988), ICF Resource 3, Inc.

2. Energy Information Administration, Investor Perceptions of Nuclear Power, DOE-EIA 0446, May 1984;

3. Energy Information Administration, An Analysis of Nuclear Power Plant Operating Costs, DOE-EIA 0511, May 1988

4. EPA Electric and Gas Utility Modeling System (EGUMS) BACT Scenarios, May 1991, RCG/Hagler, Bailly, Inc., Boulder, Colorado.

5. EPA-EGUMS, Natural Conservation Scenario, November 1990, RCG/Hagler, Bailly, Inc., Boulder, Colorado.

6. EPA-EGUMS, Federal Standards and Codes Scenarios, October 1990, RCG/Hagler, Bailly, Inc., Boulder, Colorado.

7. EPA-EGUMS, Carbon Tax Scenario, December 1990, RCG/Hagler, Bailly, Inc., Boulder, Colorado.

8. EPRI Final Report EL-2561 (RP 1529-1), Electric Generation Expansion Analysis System (Six Volumes). User's Manual, Version 4. Capabilities Manual, Version 4.

9. Gilinsky, Victor, "Nuclear Safety Regulation: Lessons from the U.S. experience," The First 50 Years of Nuclear Power: Legacy and Lessons, Financial Times of London, June 1992.

10. Goudarzi, Lessly A. and Joanne M. Shore, Transfer Pricing: A Design Consideration for Inclusion in Electricity Pricing Module of EIA Models, May 30, 1991.

11. Load Management Strategy Testing Model, May 1982, EPRI EA-2396.

12. Load Management Strategy Testing Model Case Study, February 1984, EPRI EA-3387.

13. User's Guide to LMSTM, Version 4.0, December 1989, Electric Power Software, Inc.

14. PROSCREEN II: Integrated Utility Planning and Analysis System, Overview, August 1991, Energy Management Associates, Inc., Atlanta, Georgia.

15. PROSCREEN II/PROVIEW, Sample Reports, July 1991, Energy Management Associates, Inc., Atlanta, Georgia.

16. Russel, Mitton, A Workshop on the effects of US Environmental Regulations, Energy Information Administration.

17. UPLAN-III, The Integrated Utility Planning System, Overview, LCG Consulting, Los Altos, California. 

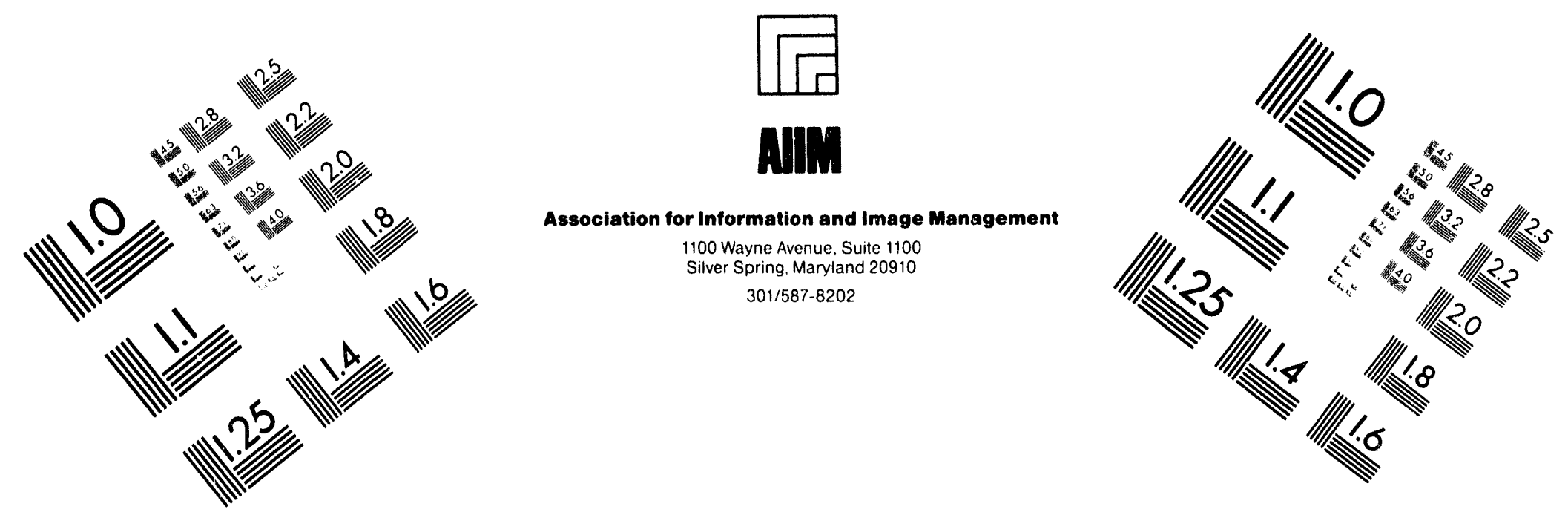

Centimeter

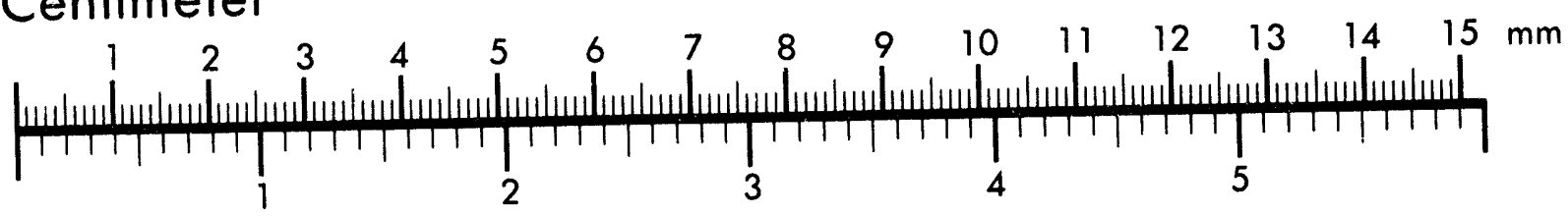

Inches
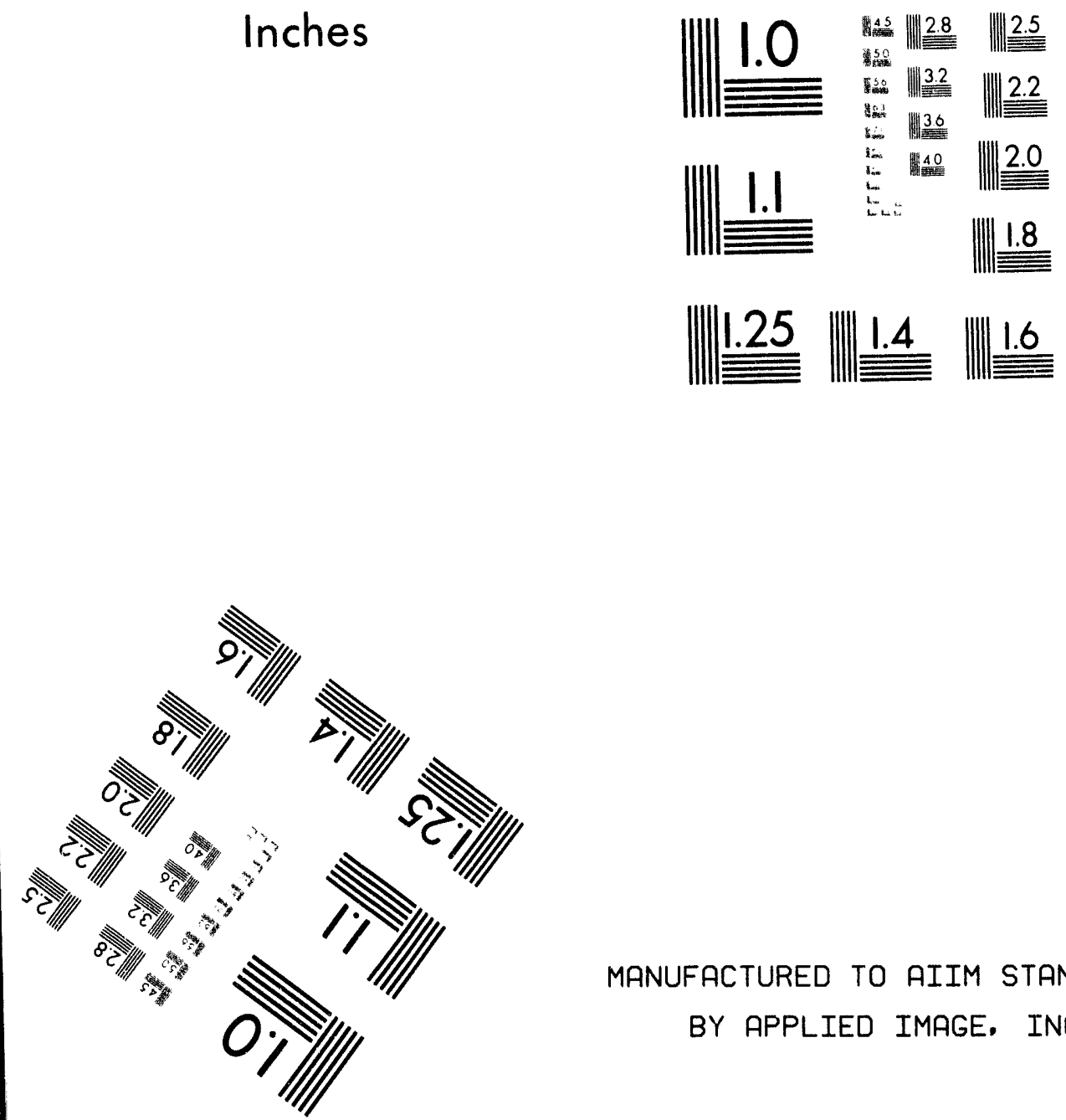

MANUFACTURED TO AIIM STANDARDS

BY APPLIED IMAGE. INC.

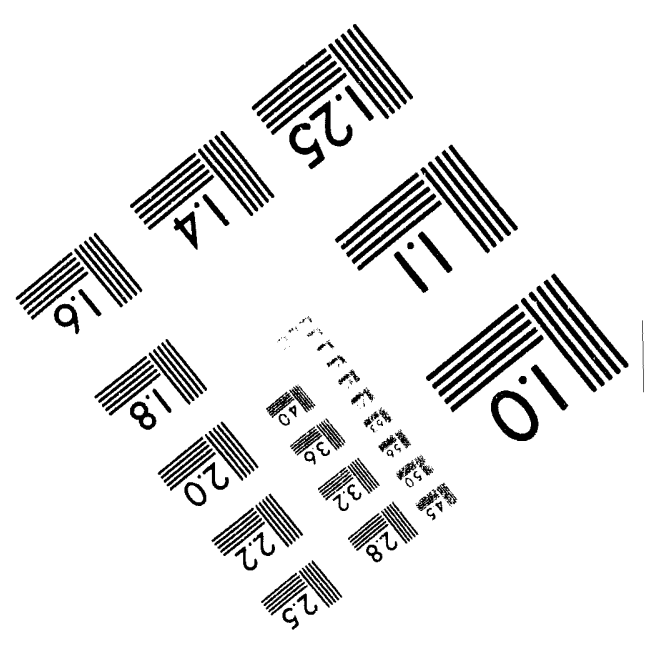



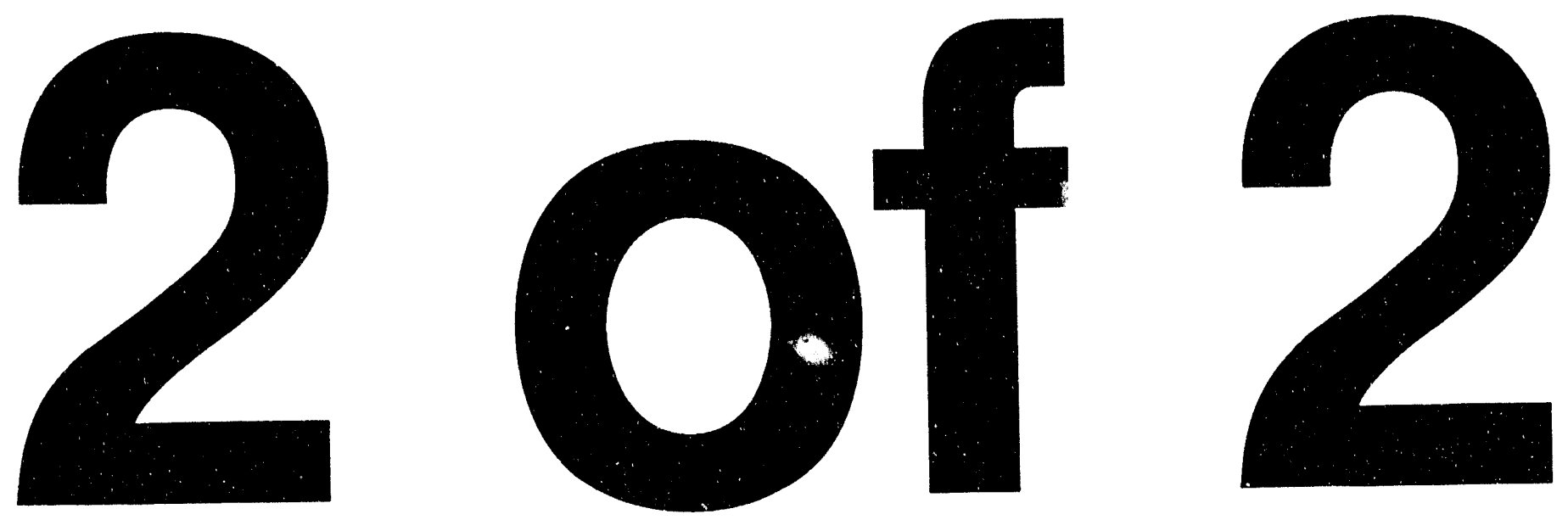


\section{Appendix E Model Abstract}

Model name:

Model Acronym:

Description:

Purpose of Model:

Model Update Information:

Part of Another Model:

Model Interface References:

Official Mociel Representative

Office:

Division:

Branch:

Model contact person:

Phone number:

Documentation References: Draft Documentation Dated March 21, 1994

\section{Electricity Finance and Pricing Submodule}

EFP

The EFP is a regulatory accounting model that projects electricity prices. The model first solves for revenue requirements ${ }^{27}$ by building up a ratebase ${ }^{28}$, calculating a return on rate base, and adding the allowed expenses. Average revenues (prices) are calculated based on assumptions regarding regulatory lag and customer cost allocation methods. The model then solves for the internal cash flow and analyzes the need for external financing to meet necessary capital expenditures. Finally, the EFP builds up the financial statements.

The EFP is used in conjunction with the National Energy Modeling System (NEMS). Inputs to the EFP include the forecast generating capacity expansion plans, operating costs, regulatory environment, and financial data. The outputs include forecasts of income statements, balance sheets, revenue requirements, and electricity prices.

Updated for the Annual Energy Outlock, 1994, December 17, 1993

Electricity Market Module

Electricity Market Module of the National Energy Modeling System

Office of Integrated Analysis and Forecasting

Energy Supply and Conversion Division

Nuclear and Electricity Analysis Branch

Art Holland

(202)596-2026

\footnotetext{
${ }^{27}$ Revenue requirements are the costs that a ratemaking authority allows a regulated utility to recover from ratepayers.

${ }^{28}$ The ratebase is the total value (original cost less accumulated straight line depreciation and exciuded tax deferrals) of all capitalized assets on which the regulated utility is allowed by a ratemaking authority to earn a return.
} 
Archive Media and Installation Manual:

Archived as Part of the National Energy Modeling System

Energy System Described by the Model:

Financial impacts of electric utilities' plans and operations

Coverage

Geographic:

National and regional

Time unit Frequency:

Annual

Product:

Electricity

Economic Sectors:

Residential, Commercial, Industrial, Transportation

Modeling Features

Model Structures:

Modeling Technique:

Finance and Accounting

Deterministic

Input Data

Non-DOE:

Regulatory Focus

Regulatory Research Associates, Inc.

Various Issues

Rural Electrification Administration

Form 7, Statistical Report, Rural Electric Borrowers

Standard and Poors Industry Surveys

Utilities-Electric, Current Analysis

May 6, 1993

DOE: $\quad$ Federal Energy Regulatory Commission

Form1, "Annual Report of Major electric Utilities, Licensees and Others"

Energy Information Administration

Form 412, "Annual Report on Public Electric Utlities"

Computing Environment: $\quad$ FORTRAN on an IBM mainframe computer

Independent Expert Reviews Conducted:

Howard Thompson (University of Wisconsin)

Doug Bohi (Resources for the Future)

Status of Evaluation Efforts Conducted by the Model's Sponsor: None to Date. 


\section{Appendix F Data Quality and Estimation}

This section describes the quality of the data used in the EFP and the estimation techniques used to prepare the data for use in the model. The individual data items are listed in Table 4 of Appendix $C$ along with their sources. The quality of the sources is discussed in this section.

\section{Regulatory Focus, Regulatory Research Associates, Inc. (RRA), Various Issues}

These data items include those that pertain to rate phase-in plans, regulatory disallowances, and sales/leaseback arrangements made by electric utilities. These data items are entered on a case by case basis from accounts of rate cases. That is, data items are gleaned by analysis from specific textual descriptions of rate phase-in plans, regulatory jisallowances, and sales-leaseback plans as described in accounts of rate cases that are published weekly by RRA in the publication Regulatory Focus. RRA reports include detailed coverage of eighty major investor-owned electric utilities.

Imprudence and excess capacity disallowances are generally reported directly in these accounts, as is the cost of new generating plants so that the fraction of the plant disallowed may be calculated. For data items related to sales-leaseback and rate phase-in plans, most are reported either directly or may be calculated from the data provided. These items include:

- book gain on sale/leaseback (sales price - utility cost to build),

- first year of phase-in period,

- year of sale/leaseback plan,

- capitalize return on deferred cost (yes or no),

- ownership type (public or private) and region of the rate phase-in or sales/leaseback plan,

- length of phase-in plan,

- book value of plant to be phased in,

- all data items regarding the rate at which total costs and deferred costs are to be phased into rates (cumulative),

- annual lease payments,

- gross sales proceeds,

- income taxes on the proceeds, and

- terms (in years) of leases.

The remaining data items concerning sales-leaseback and rate phase-in plans - assumption code for each phase-in, lowest assumption code to use in this run, and the total number of rate phase-in and sales/leaseback transactions - are judgements concerning the analyst's confidence in each record (data from each specific rate case), how to treat these assumptions in the NEMS run, and simple summations respectively. 


\section{Economic Recovery Act of 1981 (ERTA) and the Tax Reform Act of 1986 (TRA)}

All of the data items from both of these sources are specified in the legislation. Data from these sources includes:

- tax depreciation schedules,

- investment tax credit rate,

- tax recovery periods, and

- first year to flow back excess deferred taxes.

\section{Standard and Poors Industry Surveys (S\&PIS), Utilities-Electric Current Analysis, Standard and Poors Corporation, May 6, 1993}

This source is used for one data item, the cost of common equity, for each year 1990 through 1992 . These are national numbers read in directly from the text on page U5.

\section{Energy Information Administration Form 412 (EIA412), the Rural Electrification Administration Form 7 (REA7), and the Federal Energy Regulatory Commission (FERC) Form 1 (FORM1)}

These data sources are discussed together because the same data items come from these sources for both investor-owned and publicly-owned utilities unless specifically mentioned below. Input data for investor-owned electric utilities comes from the FERC Form1. Input data for Federal power projects and municipal power authorities (publicly-owned) comes from the EIA412, and data inputs for cooperatives (publicly-owned) comes from the REA7. All data items are aggregated to the Electricity Market Module by mapping routines before being input into the model or used to calculate the following data inputs.

The FERC Form 1 is the survey, "Annual Report of Major Electric Utilities, Licensees and Others". Respondents are discussed in detail in the Financial Statistics of Selected Investor Owned Electric Utilities, 1993 published by the Energy Information Administration. The ElA Form 412 is the "Annual Report of Public Electric Utilities" survey. The data for cooperatives is from the "Statistical Report, Rural Electric Borrowers". The respondents to the Rural Electrification Administration Form 7 and the EIA Form 412 are described in the Financial Statistics of Selected Publicly Owned Electric Utilities, 1993. Unless specific calculations are shown below, all of the data items used from the Form 1 and EAI412 are read in directly from data maintained by EIA's Office of Coal, Nuclear, Electricity and Alternate Fuels, and all of the data items from the Rural Electrification Administration (REA) Form 7 are read in from data maintained by the REA.

The dividend payout ratio and all data items related to common or preferred stock are from the FERC Form 1 only (because stock is only relevant to investor-owned utilities). All other data items come from all three sources. Again, details of the data items including variable names, descriptions, indices used in the model, units of measure, and storage within the model data framework are described in Table 4 of Appendix $C$. Following are the calculated data items from these three sources: 
Dividend Pavout Ratio

EDIVRT $=\quad$ CSDIV/NTERN

where:

$\begin{array}{lll}\text { EDIVRT } & = & \text { dividend payout ratio } \\ \text { CSDIV } & = & \text { common stock dividends } \\ \text { NTERN } & = & \text { net earnings }\end{array}$

General Tax Rate

$$
\text { EGTXRT = } \quad \text { (TXOTH + TXINC)/ELREV }
$$

where:

$\begin{array}{lll}\text { EGTXRT } & = & \text { general tax rate } \\ \text { TXINC } & = & \text { income taxes other than Federal income taxes } \\ \text { TXOTH } & = & \text { other taxes } \\ \text { ELREV } & = & \text { total electric revenues }\end{array}$

\section{Embedded Cost of Long Term Debt - Base Year}

ESEMDB $\quad=\quad$ LDINT/LD

where:

$\begin{array}{lll}\text { ESEMDB } & = & \text { embedded cost of long term debt }- \text { base year } \\ \text { LDINT } & = & \text { long term debt interest expense }- \text { end of year } \\ \text { LD } & = & \text { total long term debt }\end{array}$

\section{Embedded Cost of Preferred Stock - Base Year}

ESEMPB $\quad=\quad$ PSDIV/PSISS

where:

$\begin{array}{lll}\text { ESEMPB } & = & \text { embedded cost of preferred stock }- \text { base year } \\ \text { PSDIV } & = & \text { preferred stock dividends } \\ \text { PSISS } & = & \text { total preferred stock issued }\end{array}$

\section{Percent of Capitalization from Common Equity}

$$
\text { ESPRCE }=(P R C A P-P S I S S) /(P R C A P+L D+C A L I A B)
$$

where: 


$\begin{array}{lll}\text { ESPRCE } & = & \text { percent of capitalization from common equity } \\ \text { PRCAP } & = & \text { total proprietary capital } \\ \text { C,ALIAB } & = & \text { total current and accrued liability }\end{array}$

Percent of Capital Obtained with Long Term Debt

$$
\text { ESPRLT }=\quad L D /(P R C A P+L D+C A L I A B)
$$

where:

ESPRLT = percent of capital obtained with long term debt

\section{Percent of Capital Obtained with Preferred Stock}

$$
\text { ESPRPS } \quad=\quad \text { PSISS/(PRCAP + LD + CALIAB })
$$

where:

ESPRPS $=$ percent of capital obtained with preferred stock

\section{Percent of Capltal Obtained with Short Term Debt}

ESPRST $=\quad$ CALIAB/(PRCAP + LD + CALIAB

where:

ESPRST $=$ percent of capital obtained with short term debt

\section{Assumptions made by analysts at the Energy Information Administration (EIA)}

All of these data items are assumptions based on judgement by analysts at ElA. They may be decisions regarding the organization of output data items (such as the plant type names for report headers), policy assumptions (such as the percentage of CWIP allowed in the ratebase), or simplifying assumptions made in lieu of accurate data (such as the transmission energy-mile operation and maintenance costs). This later category is an indicator of future efforts to improve the quality of data inputs into the EFP. All of the data items that fall under the assumptions category are described in Table 4 of Appendix $C$ with the source designation "EIA". 

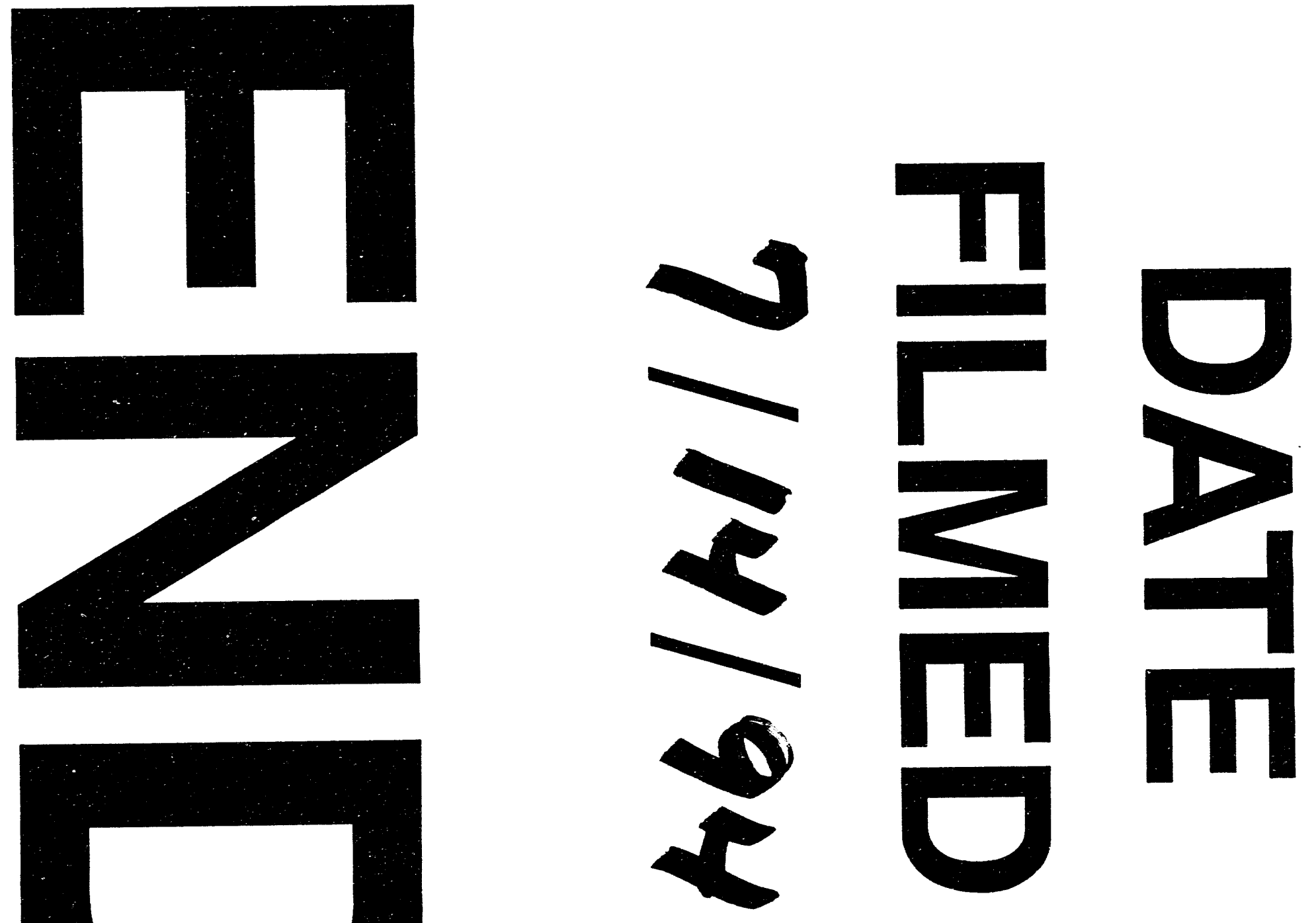

$F \mid$

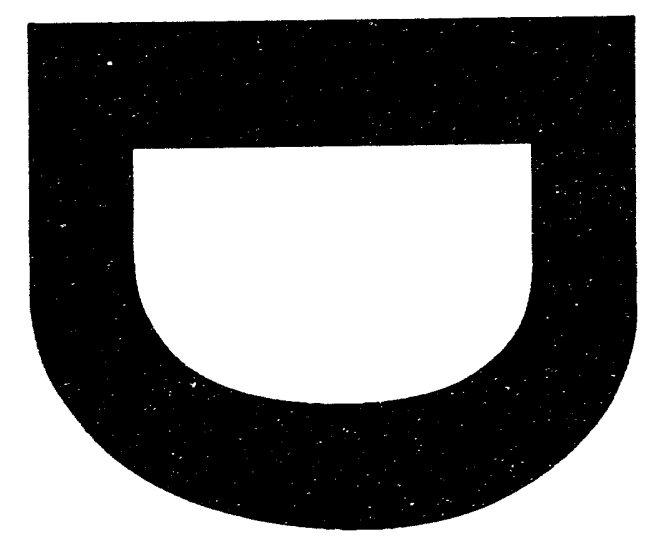


